\title{
O Geogebra como ferramenta de apoio à aprendizagem significativa em óptica geométrica
}





\title{
O Geogebra como ferramenta de apoio à aprendizagem significativa em óptica geométrica
}

\author{
Willians Gavioli da Silva
}

Orientadora: Profa. Dra. Ires Dias

Dissertação apresentada ao Instituto de Ciências Matemáticas e de Computação - ICMC-USP, como parte dos requisitos para obtenção do título de Mestre - Programa de Mestrado Profissional em Matemática. VERSÃO REVISADA 
Ficha catalográfica elaborada pela Biblioteca Prof. Achille Bassi e Seção Técnica de Informática, ICMC/USP, com os dados fornecidos pelo(a) autor(a)

G586g Gavioli da Silva, Willians
O Geogebra como ferramenta de apoio à
aprendizagem significativa em óptica geométrica /
Willians Gavioli da Silva; orientadora Ires Dias. --
São Carlos, 2015.
$90 \mathrm{p}$.
Dissertação (Mestrado - Programa de Pós-Graduação
em Mestrado Profissional em Matemática em Rede
Nacional) -- Instituto de Ciências Matemáticas e de
Computação, Universidade de São Paulo, 2015.
1. Geogebra. 2. Tecnologias Digitais. 3. Óptica
Geométrica. I. Dias, Ires, orient. II. Titulo.




\section{Dedicatória}

Dedico esse trabalho ao meu filho Guilherme Gavioli, hoje maior razão de minha existência, sei que ainda pequeno foi privado de momentos em que poderíamos estar juntos, as ausências nos fins de semana e outros momentos pelos quais me ausentei mediante esse desafio.

À Lucimar Ap. J. Gavioli, companheira nesse período, por acreditar sempre em minha capacidade de poder enfrentar os desafios proporcionados pela carreira de Educador-Pesquisador.

Aos meus familiares, Zélia Gavioli minha querida mãe, Mário Augusto, meu pai, que por suas razões me ensinou acima de tudo conquistar as coisas com muito trabalho. A conquista é minha, mas a vitória é de vocês.

Meus irmãos Wellington e Vagner Gavioli, cada um contribuindo de algum modo para minha formação pessoal.

"É somente nas misteriosas equações do amor que qualquer lógica ou razão pode ser encontrada. Você é a razão de eu estar aqui hoje, você é a razão de eu existir, você é todas as minhas razões." John Nash 



\section{Agradecimentos}

Agradeço a Deus, pela oportunidade me concedida em trilhar esse caminho, meu refúgio e minha fortaleza, pela graça de me conceder forças nos momentos em que não tinha mais, por me carregar em seus braços quando mais precisei minha eterna gratidão.

À Minha Orientadora Prof. $\stackrel{a}{\text {. Drạ. }}$. Ires Dias, que desde o primeiro dia acreditou em mim, pela disposição e orientação dedicada a esse trabalho para que o mesmo fosse realizado da melhor forma.

Aos Professores Doutores: Hermano de Souza Ribeiro, Luiz Augusto da Costa Ladeira, Miguel Vinícius Santili Frasson, Paulo Leandro Dattori da Silva, Esther P. Almeida Prado, Miriam Cardoso Utsumi, Marcia Federson e Sérgio Monari Soares, pelos valiosos ensinamentos no período que convivemos.

Aos meus colegas de curso, pelo qual muito aprendi durante esse período de convivência e que se tornaram verdadeiros amigos: Marcelo Trovão, Fábio Abrão, Leonardo Perez, Lizlaine Trevelin, Renato Fernandes, Rafael J.D. Polônio, Carlos Laércio, Bruno Azevedo, Renato Souza e Marcelo Belini.

A todos meus colegas que acreditaram nessa conquista, contribuindo para meu sucesso e minha formação como profissional e como pessoa. Sou resultado da confiança de todos. 

"Feliz aquele que transfere o que sabe e aprende o que ensina." 



\section{Resumo}

Devido às transformações que o ensino atravessa, o surgimento de novas tecnologias digitais utilizadas no ensino e diante da falta de motivação por parte dos alunos no aprendizado da matemática e da física, essa pesquisa foi concebida com o objetivo de verificar, as potencialidades do uso do software Geogebra no ensino interdisciplinar, através de atividades simuladas no Geogebra para resolução de problemas em óptica geométrica.

Palavras-chave: Geogebra, Tecnologias Digitais, Óptica Geométrica.

\section{Abstract}

Due to new technologies introduced in teaching and a lack of motivation among students to learn mathematics and physics, inspired this research to verify the potential of Geogebra software in interdisciplinary learning through activities simulated in Geogebra to solve problems on/about geometrical optics.

Keywords: Geogebra, Digital technologies, Geometric Optics. 



\section{Lista de Figuras}

Figura 1 - Interface inicial do software Geogebra........................................................ 24

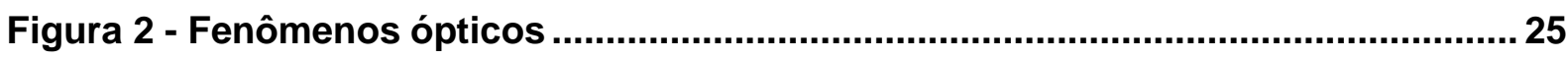

Figura 3 - Representação geométrica das leis da reflexão............................................ 26

Figura 4 - Esquema simplificado do funcionamento de uma antena parabólica. .......... 27

Figura 5 - Posição da trajetória realizada pela bola branca para atingir a bola vermelha.

Figura 6 - Representação dos triângulos formados........................................................... 28

Figura 7- Representação dos defeitos visuais: miopia e hipermetropia ......................... 29

Figura 8 - Refração da luz do meio A para o meio B ...................................................... 30

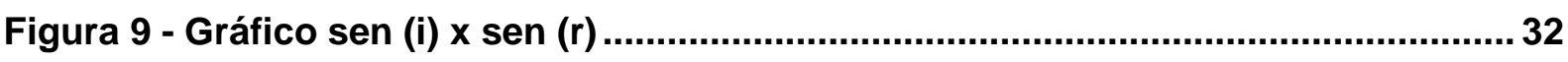

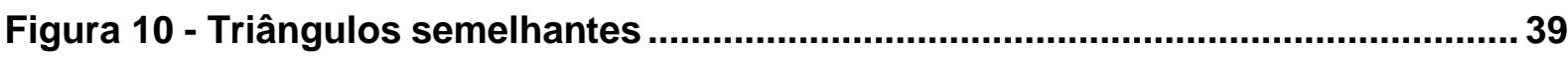

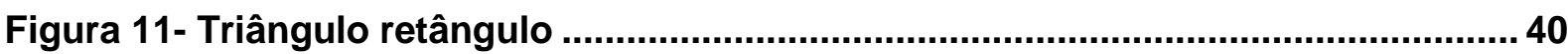

Figura 12 - Determinação do aumento linear transversal-lente convergente................. 41

Figura 13 - Determinação da Equação de Gauss.............................................................. 41

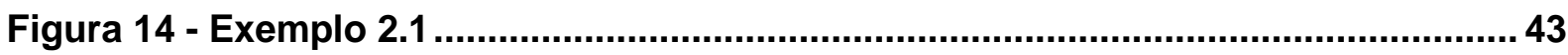

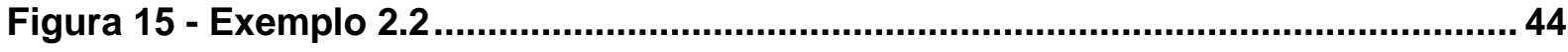

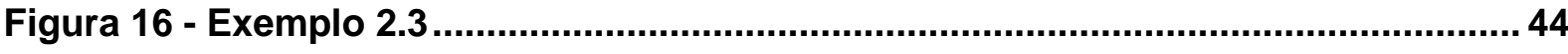

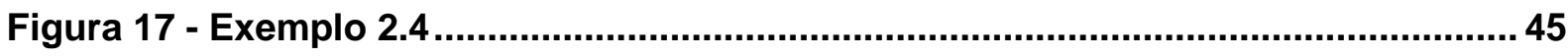

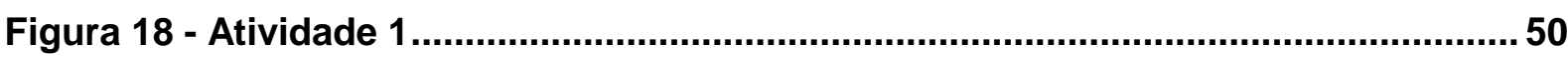

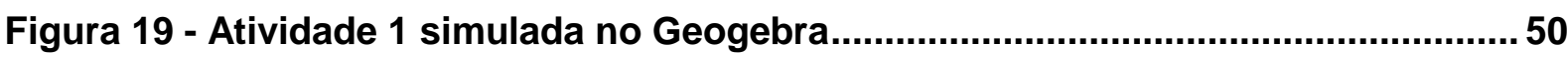

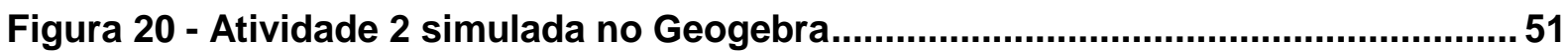

Figura 21 - Atividade 3 simulada no Geogebra.................................................................. 53

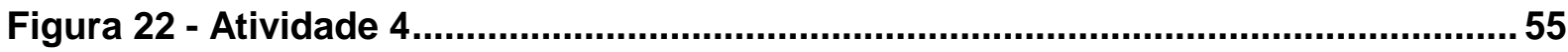

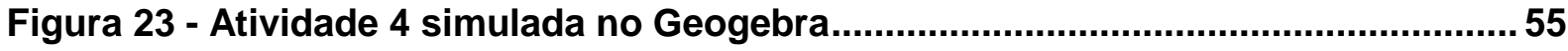

Figura 24 - Obtenção do triângulo retângulo A'LB ................................................ 56

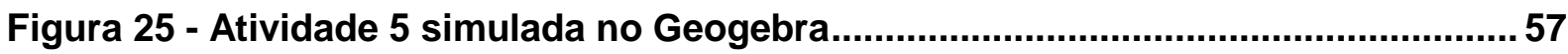

Figura 26 - Representação gráfica das imagens formadas em espelhos esféricos feitas por um aluno.......................................................................................................... 58

Figura 27 - Atividade 6 simulada no Geogebra........................................................ 62

Figura 28 - Atividade 6 simulada por um aluno sem auxílio do professor ....................62

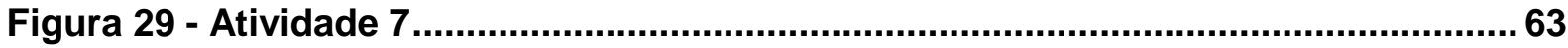

Figura 30 - Atividade 7 simulada com o Geogebra...........................................................64

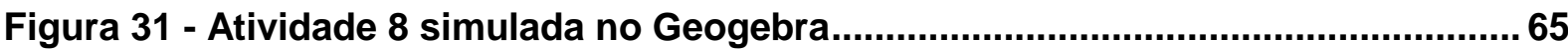

Figura 32 - Representação gráfica das imagens formadas em lentes esféricas ........... 66 



\section{Lista de Tabelas}

Tabela 1 - Medidas dos ângulos de incidência e de refração........................................31

Tabela 2 - Seno dos ângulos calculados ....................................................................... 31

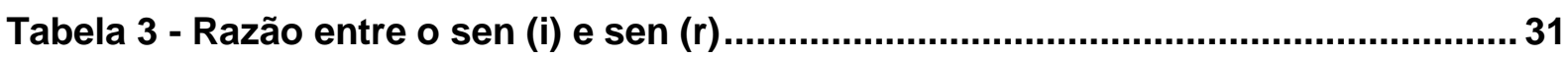

Tabela 4 - Cronograma de desenvolvimento da pesquisa...............................................36

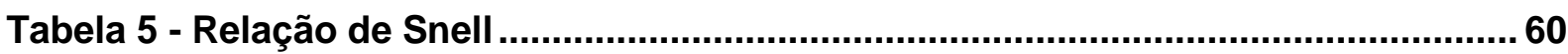

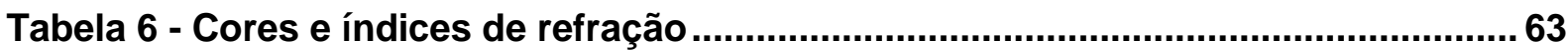

Tabela 7 - Notas dos alunos da turma $A$ antes do uso do Geogebra .............................. 70

Tabela 8 - Notas dos alunos da turma $B$ antes do uso do Geogebra............................. 71

Tabela 9 - Notas dos alunos da turma $C$ antes do uso do Geogebra ............................. 72

Tabela 10 - Nota geral dos alunos antes do uso do Geogebra.....................................73

Tabela 11 - Notas das turmas com o uso do Geogebra ................................................. 76

Tabela 12 - Nota geral dos alunos com o uso do Geogebra ..........................................76

Tabela 13 - Comparativo de notas antes e depois do uso do Geogebra .......................77

\section{Lista de Gráficos}

Gráfico 1-Rendimento turma A antes do uso do software............................................70

Gráfico 2-Rendimento turma B antes do uso do software..............................................71

Gráfico 3-Rendimento turma $\mathrm{C}$ antes do uso do software..............................................72

Gráfico 4-Rendimento geral dos alunos após o uso do software .................................77

Gráfico 5-Rendimento geral antes e depois do uso do software ...................................78 



\section{Sumário}

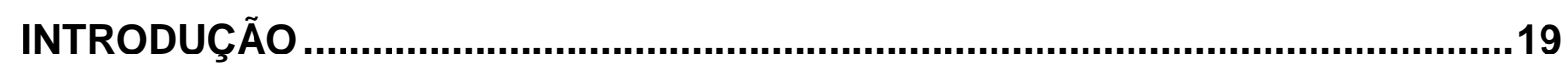

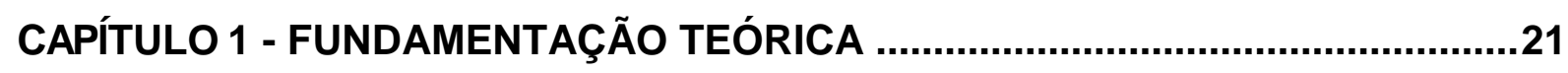

1.1 - O uso de tecnologia digital no ensino da matemática e da física .............................. 21

1.2 - O software Geogebra como tecnologia digital ................................................... 23

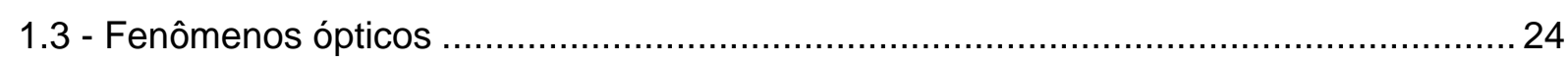

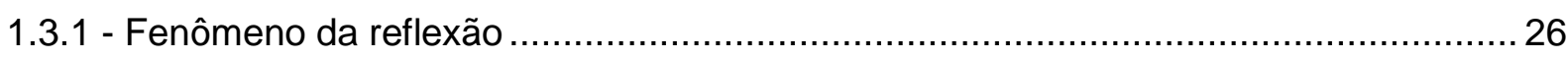

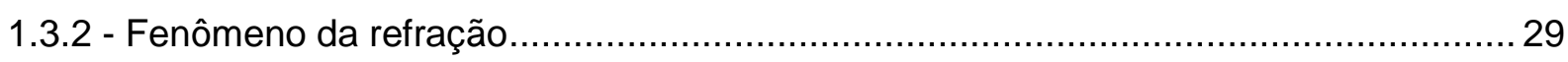

CAPÍTULO 2 - METODOLOGIA DA PESQUISA ..............................................33

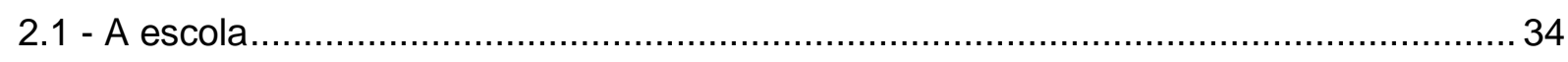

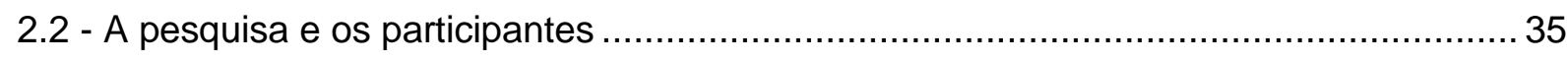

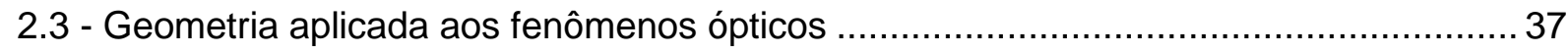

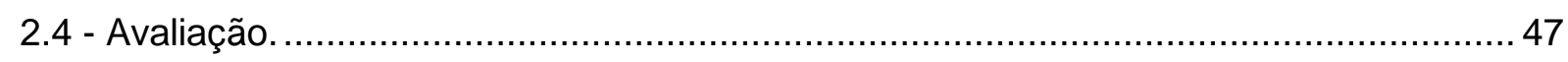

CAPÍTULO 3 - O DESENVOLVIMENTO DA PESQUISA ...................................49

3.1 - Sequência de atividades utilizando o Geogebra ................................................ 49

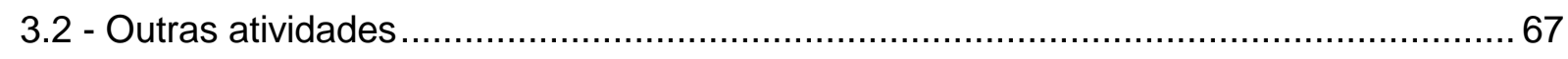

CAPÍTULO 4 - ANÁLISE DE RESULTADOS...................................................69

4.1 - Atividades utilizadas antes do uso do Geogebra e resultados .................................69

4.2 - Atividades utilizadas após o uso do Geogebra e resultados ..................................... 74

CAPÍTULO 5 - CONSIDERAÇÕES FINAIS.....................................................79

REFERÊNCIAS BIBLIOGRÁFICAS .................................................................83

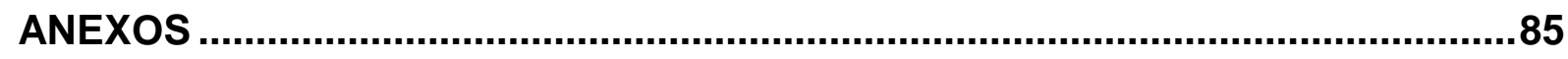





\section{Introdução}

Esta pesquisa foi concebida diante de um período de transformações em que a Educação Básica atravessa, em busca de novas metodologias e práticas de ensino, mediante um quadro de falta de motivação por parte dos alunos, é que essa pesquisa foi concebida.

Com a utilização de tecnologias digitais no ensino/aprendizagem surgiram novas possibilidades, democratizando o acesso aos diferentes níveis e modalidades de ensino. Com as novas tecnologias, ampliou-se o diálogo entre todos os envolvidos no processo, dentro deste novo paradigma. Alunos e professores se deparam com um novo modo de ensinar e aprender, rompendo barreiras com a criação de novos espaços de aprendizagem.

Ao lançar uso das tecnologias digitais para potencializar a aprendizagem, o professor contribui pedagogicamente para um outro ângulo tecnologia digital.

Porém, ao incluir tecnologias digitais no ambiente escolar, é preciso refletir, pesquisar e buscar formações a respeito do seu uso, uma vez que, não basta introduzir a tecnologia no espaço escolar, mas sim, pensar como ela irá auxiliar no processo de ensino/aprendizagem. Assim, essa pesquisa nasce dessa preocupação. Mediante ao quadro de desinteresse por grande parte dos alunos, passamos a refletir sobre estratégias para promover a motivação e o aprendizado durante as aulas.

Nesse cenário procuramos analisar o uso do software Geogebra, como recurso pedagógico para a realização de atividades escolares, na disciplina de Física, em uma escola pública na cidade de Caconde, localizada na Mesorregião de Campinas, Microrregião de São João da Boa Vista a $290 \mathrm{~km}$ da capital paulista, no Estado de São Paulo. Espera-se verificar o papel do Geogebra, como ferramenta facilitadora no processo de aprendizagem e a sua contribuição na aquisição e construção do conhecimento. Este processo envolve a interdisciplinaridade entre os alunos enquanto utilizam o software, assim como a sua em relação à construção do conhecimento.

Optamos por assim fazermos de forma interdisciplinar por nos basearmos nas teorias de Ausubel no que se refere à Aprendizagem Significativa. Trabalhamos com 
a hipótese de que o uso de tecnologias digitais, em particular o uso do Geogebra, seja nas aulas de geometria quanto nas aulas de física, poderá favorecer não apenas a aprendizagem significativa dos alunos como também verificar um quadro de motivação e da criatividade dos mesmos.

A pesquisa foi aplicada em três turmas de segunda série do Ensino Médio da rede república no município de Caconde, onde foram utilizadas 12 aulas de 50 minutos, em laboratório computacional presente na escola e em sala de aula com o projetor. Buscamos também, suporte nos estudos realizados no campo da Educação Matemática e nas Tecnologias Digitais inseridas no estudo desta ciência.

Esse trabalho, está dividido em cinco capítulos. No primeiro, realizamos uma fundamentação teórica, apresentando os principais conceitos que engloba essa pesquisa. No capítulo dois, na metodologia de pesquisa, apresentamos o campo de pesquisa, os participantes e também como será realizada a pesquisa. No capítulo três, apresentamos as atividades realizadas com os alunos utilizando o Geogebra. No capítulo quatro, apresentamos as avaliações e resultados observados com o uso do software. Por último, nas Considerações Finais, apresentamos algumas reflexões frente ao uso de tecnologias digitais no processo ensino/aprendizagem e algumas considerações frente à pesquisa realizada. 


\section{Fundamentação Teórica}

Nesse Capítulo, apresentamos alguns conceitos importantes que fundamentaram essa pesquisa. Os conceitos apresentados sintetizam uma base teórica que servirá de suporte, para a compreensão do restante do trabalho.

\section{1 - O uso de tecnologia digital no ensino da matemática e da física}

O Ensino nas últimas décadas tem passado por várias transformações, fazendo com que os educadores procurem novas metodologias e técnicas de aprendizagem, realizando uma releitura das práticas de ensino e na forma de avaliar.

Cada vez mais, o uso da tecnologia digital se estende no vasto campo do agir humano e na transmissão do conhecimento, influenciando no comportamento do indivíduo de forma isolada.

O crescente aumento do uso do conhecimento no século $X X I$, tem influenciado de forma direta nas relações interpessoais, hoje, fortemente intermediadas por instrumentos tecnológicos, impedindo que seu uso esteja limitado a sala de aula.

Com a redemocratização do ensino nos diversos níveis educacionais, características cognitivas e afetivas juntamente com a capacidade de resolver problemas, trabalhar em grupo, buscar sempre se aperfeiçoar, agir de modo cooperativo tem sido cada vez mais valorizadas.

E é nesse mundo do qual o conhecimento está cada vez mais acessível pelas redes sociais ou mesmo através das tecnologias digitais disponíveis, que se faz necessário, priorizar o verdadeiro diferencial que é a obtenção de uma educação de maior qualidade. 
É, portanto com essa linha do aprender a aprender (MORIN, 1996) ${ }^{[7]}$, que cada vez mais se torna necessário que os alunos desenvolvam suas habilidades e competências com base:

- nas características das ações e pensamentos do aluno;

- nas características pessoais e profissionais, juntamente com a qualidade das mediações do professor;

- nos conteúdos das disciplinas e as metodologias para o seu ensino e aprendizagem.

Contudo, com o intuito de dinamizar as aulas de matemática e física, acreditando que o uso de tecnologias digitais, possa colaborar significativamente com a aprendizagem provocando uma transformação no ensino dessas ciências e colaborando com a educação do aluno é que surgiu a preocupação em melhorar minha prática pedagógica, diversificando-a e ao mesmo tempo proporcionando um melhor aprendizado e difusão dos saberes que a matemática proporciona ao individuo na sua formação.

(REIS, 1995) ${ }^{[9]}$, define Tecnologia digital:

"Como um conceito polissêmico que varia segundo o contexto e a perspectiva teórica do autor, podendo ser vista como: artefato, cultura, atividade com determinado objetivo, processo de criação, conhecimento sobre uma técnica e seus respectivos processos.".

O uso dessas tecnologias digitais no ensino de matemática e física tem proporcionado o desenvolvimento de atividades de aprendizagens, tem também integrado conceitos e estratégias representadas pelos alunos, provocando maior interação entre eles, proporcionando um ambiente de aprendizagem colaborativo, capaz de transformar informações em conhecimento.

É de suma importância, que para se ter contribuições efetivas para com a aprendizagem, o uso de tecnologias digitais não pode constituir um fator essencial como pré-requisito, cabendo assim, uma atividade educativa com suporte em tecnologias digitais, possibilitar o desenvolvimento de competências relacionadas com o conhecimento proposto (SOARES, 2002) ${ }^{[12]}$.

O uso das tecnologias digitais deve contribuir para atribuir significados a informações e proporcionar motivação aos alunos na busca do conhecimento. 
Ao inserir tecnologias digitais no ensino, em particular no ensino da matemática e da física, propõe-se criar um ambiente que motive os alunos a construir o conhecimento. Assim, utilizar uma tecnologia digital, é utilizar-se de uma ferramenta que dará suporte ao processo ensino/aprendizagem. É tão somente um meio, embora muito importante, que possibilita novas formas de construção do conhecimento e de provocação à participação dos estudantes.

A presença da tecnologia digital deve servir para o enriquecimento do ambiente educacional, propiciando a construção do conhecimento por meio de uma atuação ativa e crítica por parte de alunos e professores.

\section{2 - O software Geogebra como tecnologia digital}

Este trabalho tem como objetivo, motivar os alunos a aprender conceitos físicos relacionados à óptica geométrica utilizando o software Geogebra como tecnologia digital, de forma que os alunos possam interagir diretamente na construção do conhecimento e dessa forma ter uma aprendizagem significativa, sobretudo utilizando elementos ou conceitos básicos de geometria.

O software foi desenvolvido por Markus Hohenwarter, professor da Universidade de Salzburg, em 2001. Seu objetivo principal é o de dinamizar o estudo da matemática, utilizando álgebra e geometria, de modo a facilitar a investigação e o estudo de vários conceitos matemáticos e áreas afins que utilizam recursos geométricos ou algébricos, podendo ser utilizado como recurso pedagógico em diferentes níveis e modalidades de ensino.

De fácil acesso e utilização pode ser encontrado na Internet sem custo ao usuário. Sua instalação é rápida e não precisa ter domínio de informática para executá-lo, que é uma das grandes vantagens oferecidas pelo software em relação a outras tecnologias digitais disponibilizadas.

Nesse trabalho, achamos dispensável apresentar ferramentas proporcionadas pelo software Geogebra, uma vez que não corresponde ao foco da pesquisa, no entanto, há diversos links disponibilizados na Internet para que o mesmo possa ser instalado gratuitamente, por exemplo, através do endereço: www.geogebra.at.

$\mathrm{Na}$ Figura 1 representamos a interface inicial do programa. 


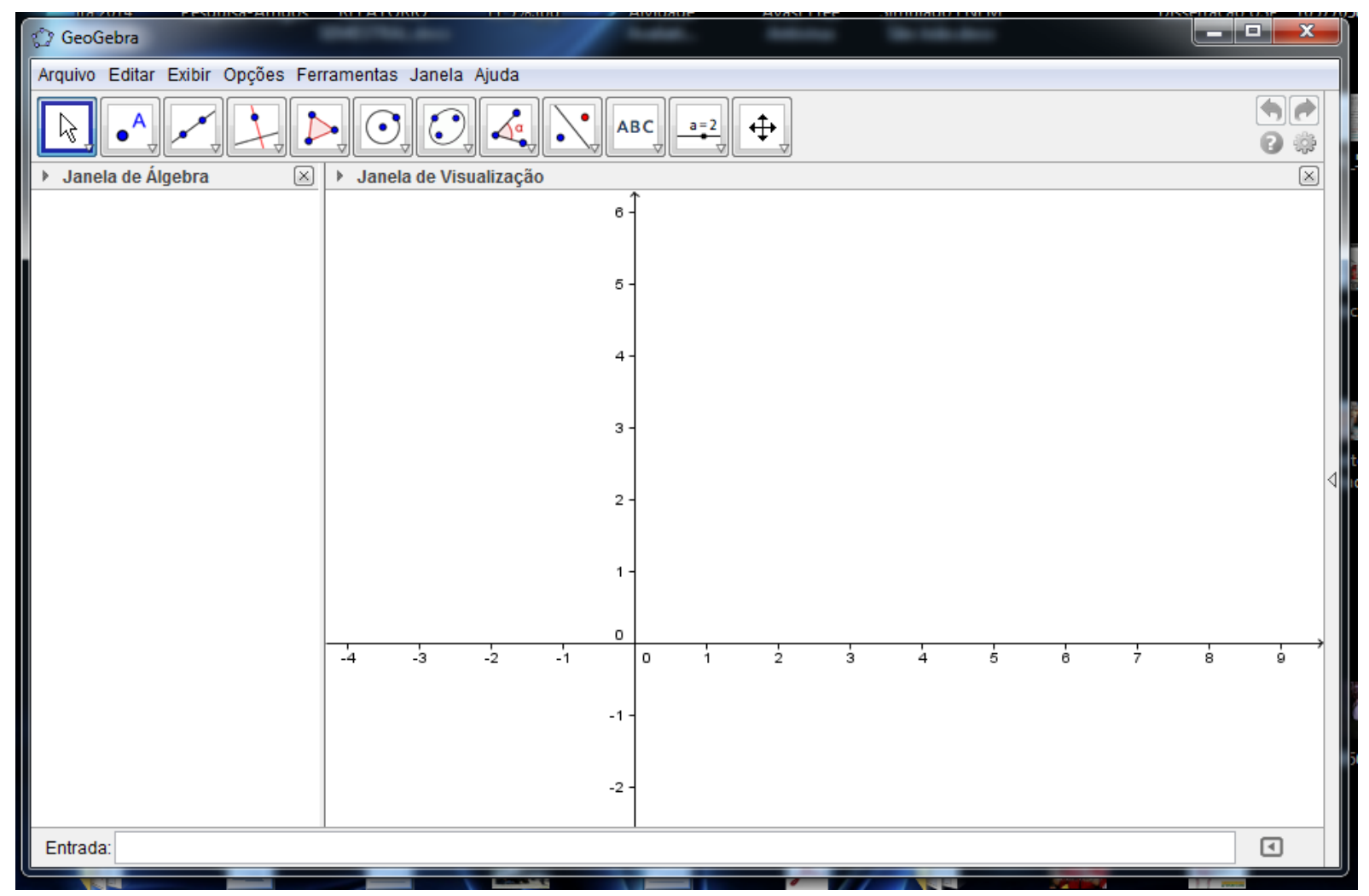

Figura 1 - Interface inicial do software Geogebra.

Utilizamos o software Geogebra como tecnologia digital, com o intuito de incentivar a motivação dos alunos, a compreensão das informações, sua contextualização e verificar se o conhecimento foi de fato adquirido. Para sua utilização, desenvolvemos atividades didáticas que envolvem fenômenos físicos ligados à óptica geométrica.

\section{3 - Fenômenos ópticos}

Fenômenos, no contexto geral, representam algo de extraordinário, porém em ciência o conceito está relacionado aos acontecimentos relacionados à natureza, podendo ser físicos ou químicos. O fenômeno físico se caracteriza como qualquer evento natural que pode ser observado e possível de ser medido diretamente ou indiretamente por algum aparelho ou instrumento, não há alteração nas substâncias de modo geral que compõem a matéria, como por exemplo uma descarga elétrica através de um raio e a mudança de estado físico de uma substância. Em contradição, um fenômeno químico embora se caracterize como um evento natural que pode ser observado e medido, as substâncias que compõe a 
matéria sofrem alterações, como por exemplo a queima do papel ou uma reação entre um ácido e uma base.

No estudo do comportamento geométrico da luz, destacam-se quatro fenômenos ópticos:

Reflexão Regular: Caraterizada pelo paralelismo dos raios de luz que incidem sobre uma superfície lisa e polida, retornando para o meio de origem, mantendo o paralelismo entre os raios de luz, conforme representado na Figura 2a.

Reflexão Difusa ou Difusão: Caracteriza-se pelo paralelismo dos raios de luz que incidem sobre uma superfície lisa e irregular, de modo que ao retornar para o meio de origem, a luz perde a propriedade de paralelismo conforme a Figura 2b.

Refração: Se caracteriza pela passagem da luz de um meio para outro de características diferentes ao do meio de incidência, podendo sofrer desvios em sua trajetória ou, em casos particulares, manter sua trajetória em incidência normal, como representado na Figura 2c.

Absorção: Caracterizada pela incidência de luz em uma superfície que absorve a luz convertendo a energia luminosa em energia térmica conforme representado na Figura $2 \mathrm{~d}$.

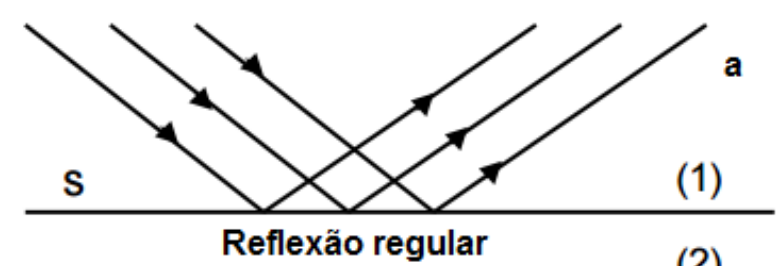

(2)

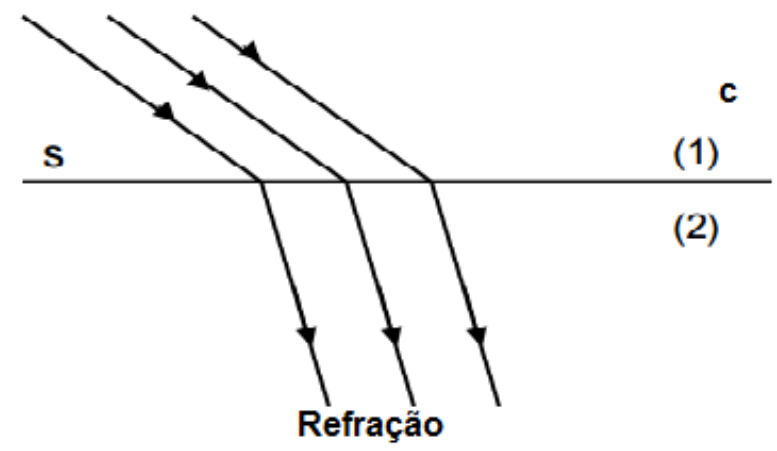

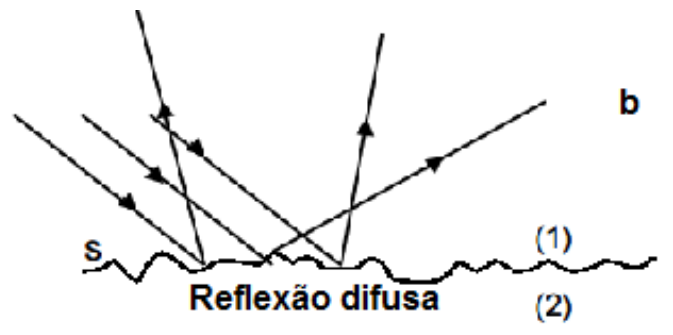

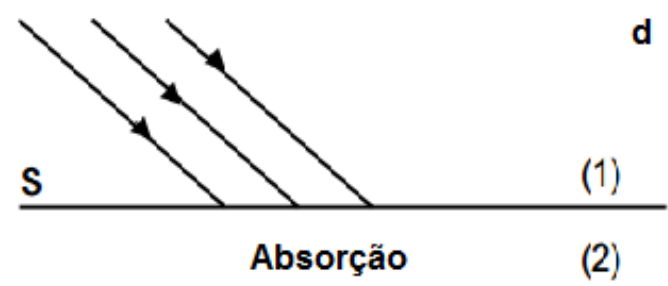

(2)

Figura 2 - Fenômenos ópticos

Para nossa pesquisa, utilizaremos atividades relacionadas à Reflexão e a Refração, destacando que, nenhum dos fenômenos, ocorre de forma isolada. 


\subsection{1 - Fenômeno da reflexão}

Como enunciado no item anterior, trata-se da incidência da luz sobre uma superfície regular lisa e polida caracterizando a Reflexão Regular, ou a incidência dos raios de luz sobre uma superfície lisa, porém irregular, caracterizando, a Reflexão Difusa ou o fenômeno da Difusão.

A reflexão pode ser observada em vários objetos ou mesmo em atividades do nosso dia-a-dia, podendo ocorrer em espelhos planos, esféricos, ou ainda pelo simples fato de enxergarmos um objeto, já que para vê-lo a luz, proveniente de uma fonte primária, incide sobre o objeto e por sua vez reflete a parcela de luz que irá sensibilizar as células responsáveis pela nossa visão.

Para fins didáticos representamos a luz por um segmento de reta, utilizando um dos princípios da óptica geométrica, que é o Princípio Retilíneo da Luz.

Esse Princípio indica que em meios homogêneos, translúcidos e transparentes a luz se propaga em linha reta.

As Leis da Reflexão que caracterizam o fenômeno são indicadas a seguir:

\section{1․ Lei da Reflexão:}

"O raio incidente $(R I)$, o raio refletido $(R R)$ e a reta normal $(N)$ são coplanares."

\section{2ª Lei da Reflexão:}

"O ângulo de incidência (i) é igual ao ângulo de reflexão (r)."

Podemos observar a representação geométrica na Figura 3, a seguir.
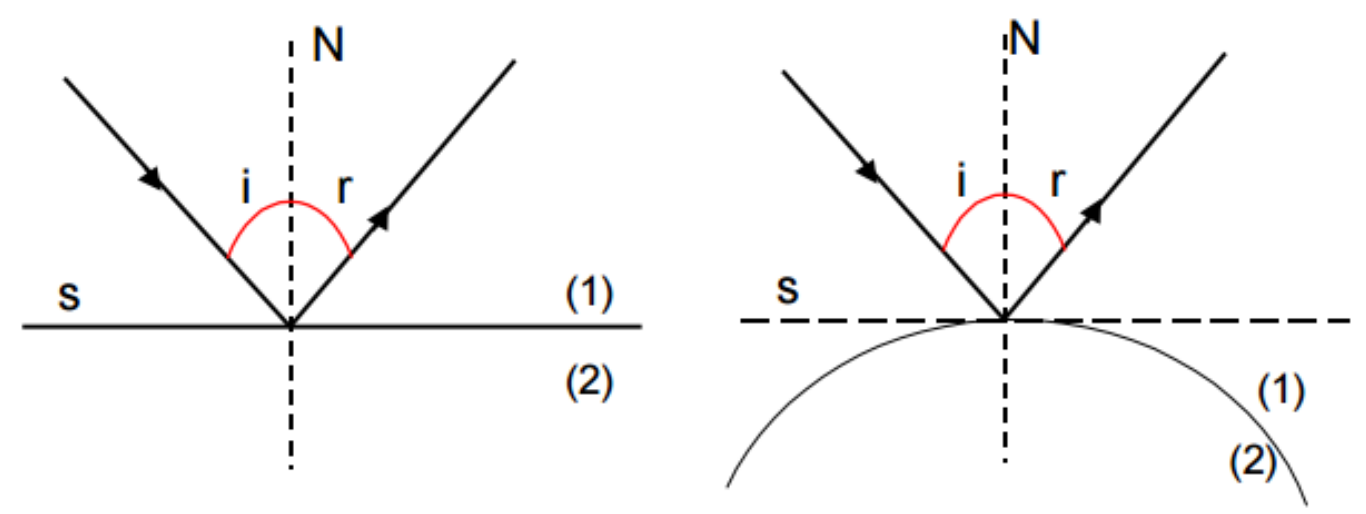

Figura 3 - Representação geométrica das leis da reflexão 
O estudo da Reflexão, muitas vezes, se limita ao entendimento de como as imagens se formam em espelhos planos e esféricos. Mas, podemos observar na Figura 4, que este estudo implica em equipamentos que são utilizados envolvendo não apenas a reflexão de luz, mas também, as ondas eletromagnéticas não visíveis no caso de ondas de rádio e TV. Em instrumentos como máquinas fotográficas, telescópios, retroprojetores, aparelhos de leitura a laser, microscópios, também podemos identificar esse fenômeno. As miragens e o uso de fibra óptica também podem ser explicados por esse fenômeno.

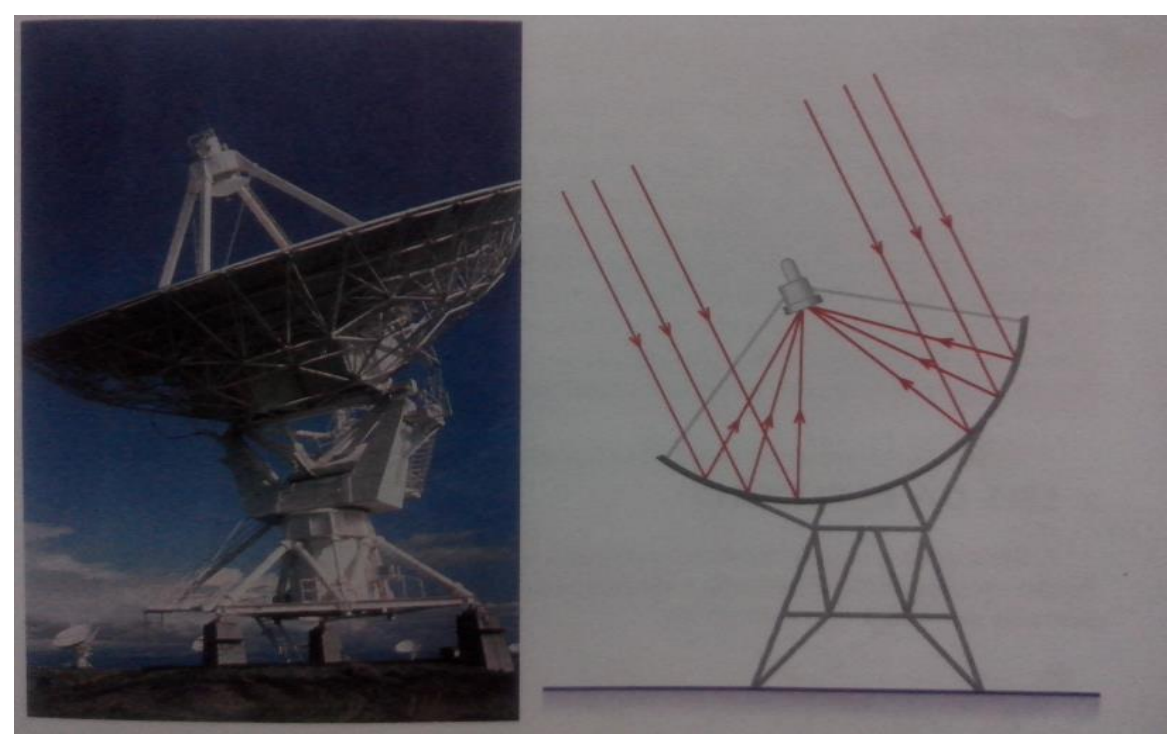

Figura 4 - Esquema simplificado do funcionamento de uma antena parabólica.

Fonte Livro Texto Anglo Sistema de Ensino 2002.

A seguir uma aplicação direta dessas leis e também da semelhança de triângulos, contextualizada com o jogo de bilhar. Trata-se de uma questão da FUVEST da prova de matemática de 2010 , da segunda fase do concurso vestibular.

\section{Questão:}

Em uma mesa de bilhar, coloca-se uma bola branca na posição $B$ e uma bola vermelha na posição $\mathrm{V}$, conforme o esquema abaixo representado na Figura 5.

Deve-se jogar a bola branca de modo que ela siga a trajetória indicada na figura e atinja a bola vermelha. Assumindo que, em cada colisão da bola branca com uma das bordas da mesa, os ângulos de incidência e de reflexão são iguais, a que distância $x$ do vértice $Q$ deve-se jogar a bola branca? 


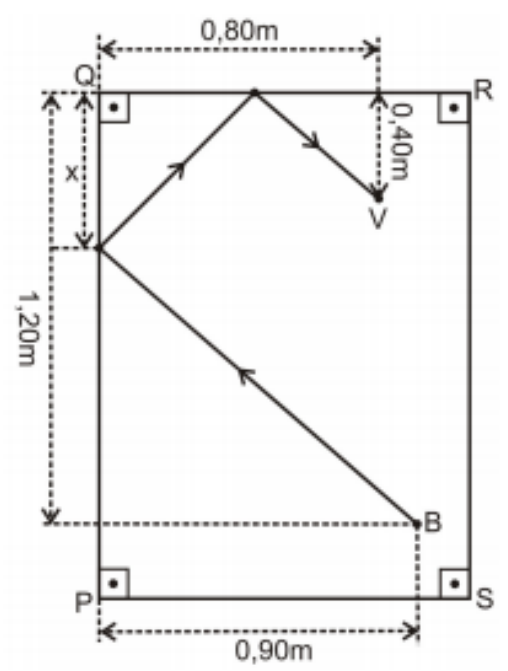

Figura 5- Posição da trajetória realizada pela bola branca para atingir a bola vermelha.

Para a resolução da questão verifica-se que o fenômeno da colisão da bola, com a borda da mesa, obedece às mesmas leis da reflexão da luz. A informação da questão: "Assumindo que, em cada colisão da bola branca com uma das bordas da mesa, os ângulos de incidência e de reflexão são iguais...", refere-se a uma das Leis da Reflexão: o ângulo de incidência (i) é igual ao ângulo de reflexão (r), onde esses ângulos são medidos em relação à reta normal.

De acordo com as informações da questão, pode-se construir a Figura 6 abaixo, no qual os triângulos retângulos $\Delta B \hat{A} D, \Delta D \hat{Q} T$ e $\Delta V \hat{E} T$ são semelhantes, e possuem os ângulos agudos congruentes, então seus lados correspondentes são proporcionais.

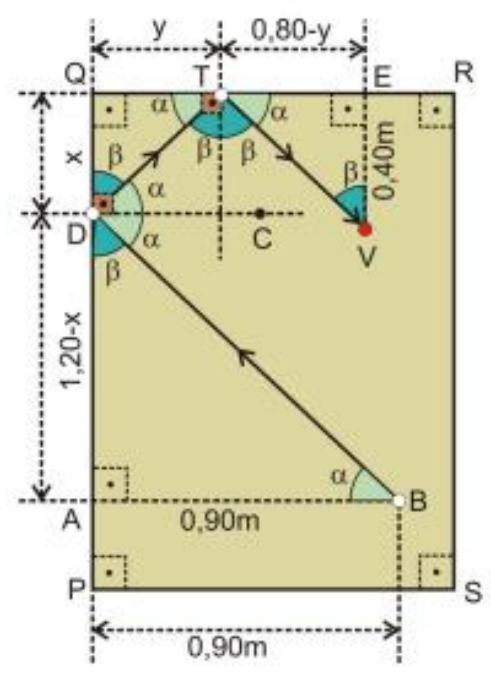

Figura 6- Representação dos triângulos formados.

Assim, 


$$
\frac{0,40}{0,80-y}=\frac{x}{y}=\frac{1,20-x}{0,90},
$$

o que implica que

$$
0,4 y=0,8 x-x y, \text { e } 1,2 y-y x=0,9 x .
$$

Obtemos então,

$$
\frac{0,4+x}{1,2-x}=\frac{8}{9}
$$

de onde segue que

$$
17 x=6,
$$

ou seja

$$
x=\frac{6}{17} m .
$$

\subsection{2 - Fenômeno da refração}

A Refração caracteriza-se pela passagem da luz de um meio para outro de características diferentes. Podemos verificar que a visão é um importante exemplo onde ocorre o fenômeno da Refração. Para a formação de imagens projetadas na retina a luz sofre Refração acentuada na córnea e em seguida no cristalino, principais estruturas do globo ocular. Porém quando os raios de luz que incidem em nosso olho, não se projetam sobre a retina, ocorre o aparecimento de defeitos visuais, entre eles, miopia ou hipermetropia, representado na Figura 7, a seguir:

A visão normal se apresenta quando a luz foca diretamente sobre a retina e não na frente ou por trás dela

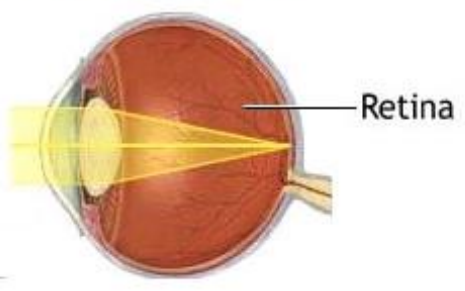

Miopia: a imagem visual foca na A hipermetropia: a imagem visual foca frente da retina por trás da retina
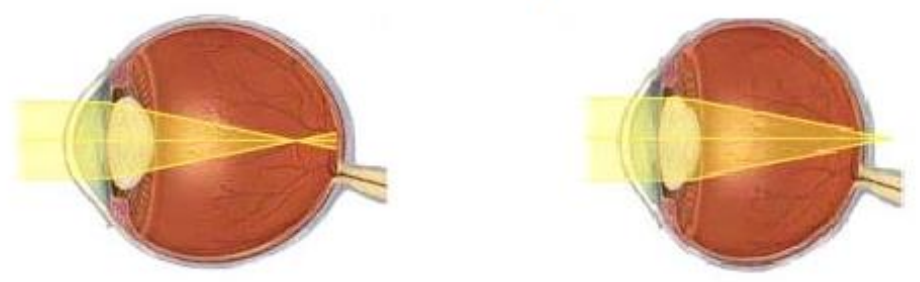

Figura 7- Representação dos defeitos visuais: miopia e hipermetropia 
A miopia consiste na dificuldade de enxergarmos objetos que se encontram a distâncias superiores a dois metros. Nesse caso o conjunto córnea-cristalino se comporta de maneira muito convergente, e os raios de luz não se projetam na retina. Para sua correção, devemos utilizar lentes delgadas divergentes para corrigir o defeito visual.

A hipermetropia consiste na dificuldade de enxergarmos objetos a uma distância de 25 centímetros, pelo fato do conjunto córnea-cristalino se comportar de forma pouco convergente. Assim, para correção desse defeito visual devemos utilizar lentes convergentes para aumentar a convergência do conjunto córneacristalino, fazendo com que os raios de luz se projetem na retina.

O que permite verificar desvios em sua trajetória é a refringência do meio, que consiste na dificuldade ou resistência provocada pelo meio à passagem da luz, que esse meio proporciona. Assim, o índice de refração absoluto é inversamente proporcional à velocidade com que a luz percorre o meio, bem como o ângulo de incidência da luz sobre a superfície que separa os dois meios. Na relação a seguir, $n$ representa $o$ índice de refração absoluto, $c$ a velocidade da luz no vácuo e $v$ a velocidade de propagação no meio, compondo a fórmula para calcular o índice de refração absoluto:

$$
n=\frac{c}{v} .
$$

Para o estudo das Leis da Refração, iremos partir de uma experiência em um ambiente mais escuro, utilizando-se de uma lanterna que emite uma luz monocromática. Ao passar de um meio refringente $A$ (utilizaremos $o$ ar) para um meio refringente $B$ (um líquido qualquer) e conhecidos seus respectivos índices de refração, $n_{A R}=1$ e $n_{\text {Liouido }}=1,5$, a luz sofrerá refração.

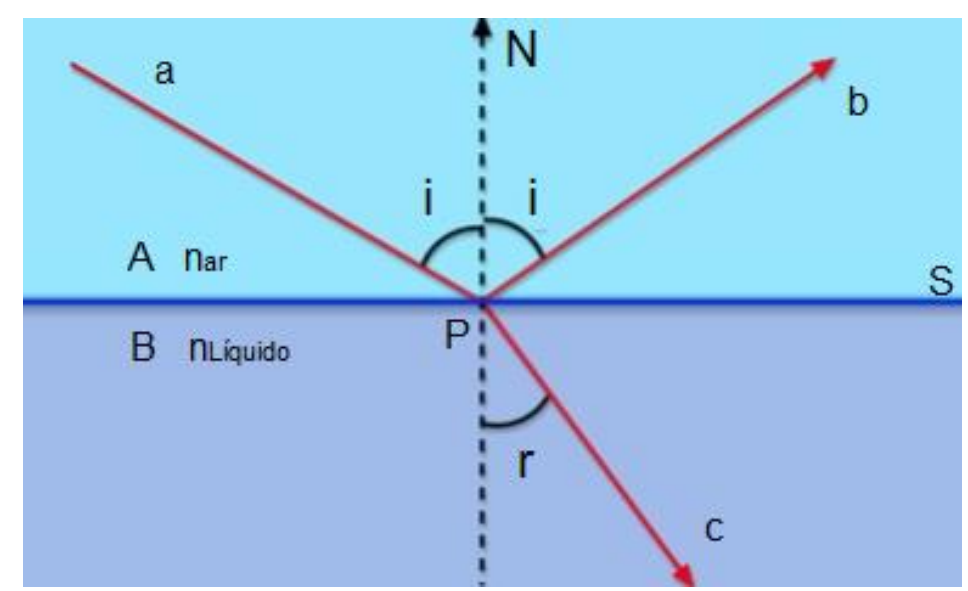

Figura 8 - Refração da luz do meio A para o meio B 
Na Figura 8, a é o raio incidente, b o raio refletido, c o raio refratado, i o ângulo de incidência e refletido, $\mathbf{r}$ representa o ângulo de refração, $\mathbf{S}$ a superfície de separação entre os meios $\mathrm{A}$ e $\mathbf{B}$ e $\mathbf{N}$ a reta normal.

Nessa experiência verificamos que o raio de luz refratado está contido em um plano de incidência (plano determinado pelo raio incidente, à reta normal e o raio refletido à superfície de separação entre os meios, no ponto de incidência $P$ ).

Observamos que não existe relação matemática entre o ângulo de incidência e o ângulo de refração. A relação que se observa é que ao aumentar o ângulo de incidência aumenta-se o ângulo de refração, representada na Tabela 1.

Tabela 1 - Medidas dos ângulos de incidência e de refração

\begin{tabular}{|c|c|c|c|c|c|c|c|c|c|c|}
\hline $\mathrm{i}$ & $0^{\circ}$ & $10^{\circ}$ & $20^{\circ}$ & $30^{\circ}$ & $40^{\circ}$ & $50^{\circ}$ & $60^{\circ}$ & $70^{\circ}$ & $80^{\circ}$ & $90^{\circ}$ \\
\hline $\mathrm{r}$ & $0^{\circ}$ & $6,65^{\circ}$ & $13,18^{\circ}$ & $19,47^{\circ}$ & $25,37^{\circ}$ & $30,71^{\circ}$ & $35,26^{\circ}$ & $38,79^{\circ}$ & $41,04^{\circ}$ & $41,81^{\circ}$ \\
\hline
\end{tabular}

Utilizando uma calculadora, representamos os respectivos senos dos ângulos de incidência (i) e o de refração ( $r$ ) na tabela 2.

Tabela 2 - Seno dos ângulos calculados

\begin{tabular}{|c|c|c|c|c|c|c|c|c|c|c|}
\hline sen $\mathrm{i}$ & $0^{\circ}$ & 0,1736 & 0,3420 & 0,5000 & 0,6428 & 0,7660 & 0,8660 & 0,9397 & 0,9848 & 1,0000 \\
\hline $\operatorname{sen} \mathrm{r}$ & $0^{\circ}$ & 0,1158 & 0,228 & 0,3333 & 0,4285 & 0,5107 & 0,5773 & 0,6265 & 0,6566 & 0,6667 \\
\hline
\end{tabular}

Determinarmos a razão entre o sen(i) e sen(r) e verificamos que a mesma se mantém praticamente constante com exceção do primeiro valor da tabela.

Tabela 3 - Razão entre o sen (i) e sen (r)

\begin{tabular}{|c|c|c|c|c|c|c|c|c|c|c|}
\hline $\operatorname{sen}(i)$ & _- & 1.499 & 1.500 & 1.500 & 1.500 & 1500 & 1.500 & 1500 & 1.500 & 1500 \\
\hline $\operatorname{sen}(r)$ & - & 1,499 & 1,500 & 1,300 & $1, J \cup 0$ & 1,500 & 1,500 & 1,300 & 1,500 & 1,500 \\
\hline
\end{tabular}

Essa relação foi determinada de forma independente pelo francês Descartes e o holandês Snell no início do século XVII ficando assim, conhecida como Lei de Snell (ou Snell-Descartes).

Em símbolos:

$$
\frac{\operatorname{sen}(i)}{\operatorname{sen}(r)}=k
$$


Assim, se $\operatorname{sen}(i)=k$.sen $(r)$ para sen $(i)=0$ temos que $\operatorname{sen}(r)=0$. Ou seja, para $\mathrm{i}=0$, o correspondente valor do ângulo de refração também é zero. Com os valores de $\operatorname{sen}(i)$ e sen(r) obtidos a partir das tabelas anteriores, obtemos o gráfico representado na Figura 9, a seguir:

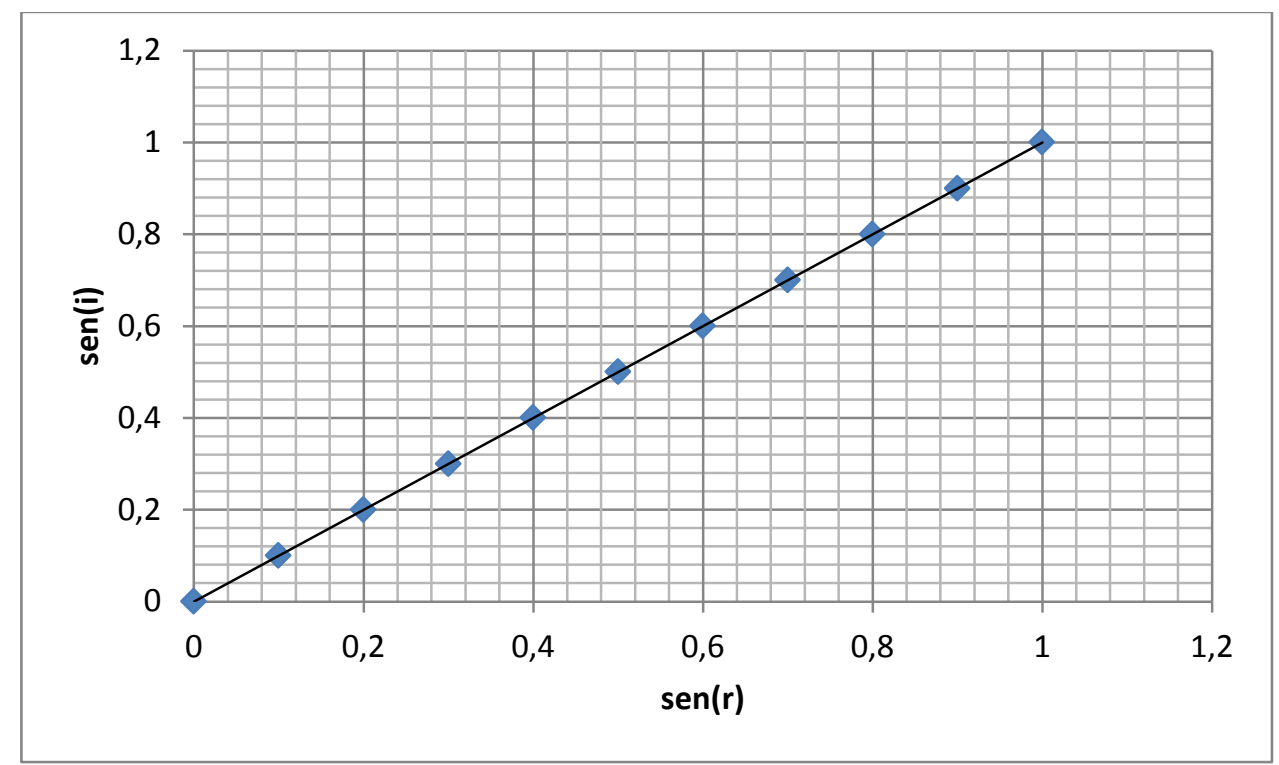

Figura 9 - Gráfico sen (i) $x$ sen (r)

Outra observação que verificamos, é que a constante $k$ tem valor praticamente igual a 1,5 , que é a razão entre os índices de refração do meio $B$ em relação ao meio A:

$$
k=\frac{n_{\text {liquido }}}{n_{\text {ar }}}=\frac{v_{\text {ar }}}{v_{\text {liquido }}}=1,5 .
$$

Assim, podemos concluir que:

- O raio refratado está contido no plano de incidência

- Quando o ângulo de incidência aumenta, seu correspondente ângulo de refração também aumenta.

- O sen(r) é diretamente proporcional ao sen(i). A constante de proporcionalidade é a razão entre os índices de refração dos meios que matematicamente pode ser representado por:

$$
\frac{\operatorname{sen}(i)}{\operatorname{sen}(r)}=\frac{n_{2}}{n_{1}}=\frac{v_{1}}{v_{2}}=k
$$

Onde $\mathrm{n}_{2} \mathrm{o}$ índice de refração do meio que a luz atravessa e $\mathrm{n}_{1} 0$ índice de refração absoluto do meio de onde a luz provém. 


\section{CAPÍTULO 2}

\section{Metodologia da Pesquisa}

Diante de um quadro de desmotivação por parte dos alunos no aprendizado da matemática, e consequentemente, dos fenômenos físicos, passamos a procurar melhorias na prática docente, buscando novos recursos que fossem capazes de estimular a motivação dos alunos, e, portanto, a aprendizagem dos mesmos.

Ao ingressar no mestrado profissional, pude então verificar muitas possibilidades para enriquecer minhas práticas pedagógicas, sobretudo com o uso de tecnologias digitais, em particular o uso do software Geogebra.

Definido os procedimentos e regras a serem utilizadas por um determinado método, o desafio é seguir as normas estabelecidas para que possamos atingir o objetivo da pesquisa, como define (RICHARDSON, 1999) ${ }^{[10]}$ sobre o conceito de metodologia.

A pesquisa tem seu fundamento inicial, na elaboração de atividades propostas com o uso do Geogebra como ferramenta facilitadora no processo ensino/aprendizagem. Assim, focamos na construção de atividades utilizando o software, para que posteriormente aplicado em sala de aula, verificássemos a aprendizagem envolvendo os conceitos de geometria e fenômenos físicos ligados a Luz.

Dessa forma, foi necessário o estudo e aprofundamento teórico sobre as teorias de aprendizagens, leituras dos Parâmetros Curriculares Nacionais, a proposta Curricular do Estado de São Paulo, (uma vez que nosso público alvo são alunos da escola pública do Estado de São Paulo), a matemática aplicada no Ensino Médio, artigos relacionados à Educação, mais especificadamente ao uso de Tecnologias digitais e textos que estivessem ligados ao tema ensino-aprendizagem de matemática, correlacionados ao ensino da geometria e óptica geométrica. 
Limitamos a pesquisa ao material computacional disponível no ambiente escolar. Em se tratando da escola a ser aplicada a pesquisa, não tivemos problemas, uma vez que, encontramos ambiente computacional disponível e em perfeito funcionamento.

\section{1 - A escola}

A escola onde desenvolvemos a pesquisa está localizada em Caconde, no estado de São Paulo. Trata-se de uma escola Pública, que mediante avaliações externas apresenta destaque em sua Diretoria de Ensino, localizada na cidade de São João da Boa Vista.

Para a pesquisa, verificamos as possibilidades de inserir na escola o uso do software Geogebra de modo que houvesse critérios mínimos, como infraestrutura física. Um fator de grande importância foi à verificação da existência de um laboratório de informática.

A fundação da Escola Estadual Professor Fernando Magalhães é datada de 1945. Com aproximadamente 1200 alunos, que cursam desde o sexto ano (antiga $5^{\text {a }}$ série) do Ensino Fundamental até a terceira série do Ensino Médio. A escola possui laboratório de Informática, com 20 computadores, adquiridos pela Secretaria de Educação do Estado de São Paulo através de projetos e outras parcerias. Todos os computadores estão ligados em rede com acesso a Internet. Conta com técnicos em informática nos três períodos de funcionamento, o que facilita o uso do laboratório.

As salas possuem recursos tecnológicos como projetores, telas de projeção, aparelhos de DVD ou na falta de projetores, TVs, todos em pleno funcionamento e sempre disponíveis para uso.

A escola apresenta 16 salas de aulas, sala da diretoria, sala dos professores, sala de recursos multifuncionais para Atendimento Educacional Especializado (AEE), uma quadra de esporte coberta e duas descobertas, cozinha e refeitório, sala de leitura e biblioteca, banheiros dentro do prédio, dependências e vias adequadas a alunos com deficiência ou mobilidade reduzida, secretaria, sala de coordenação, salão de apresentações (auditório), pátio coberto e descoberto, área verde e laboratório de informática, já mencionado acima. 


\section{2 - A pesquisa e os participantes}

A pesquisa foi fundamentada e teve como objeto de estudo, o uso de atividades exploradas através do uso do Software Geogebra no ensino de conceitos geométricos aplicados na resolução de problemas, em óptica geométrica. Sendo necessário um ambiente computacional que serviu como ferramenta para o desenvolvimento da aprendizagem, que teve como protagonistas alunos que cursaram regularmente a segunda série do Ensino Médio, no total de 84 alunos.

As aulas de física possuem duração de cinquenta minutos, onde foram desenvolvidos os conceitos relacionados à óptica geométrica e a construção das atividades utilizando o software Geogebra.

Verificamos, como hipótese de pesquisa, que o uso de recursos computacionais através de tecnologias digitais, aplicadas em atividades de construção e exploração, são ferramentas cognitivas facilitadores, para que seja atingida a aprendizagem e que em função do tempo de aplicação o software não poderia ser ao todo, de extremo domínio por parte dos alunos.

Por se tratar de uma pesquisa, que tem por objetivo aprendizagem de conceitos de geometria e aplicação em fenômenos físicos, através de atividades exploratórias, utilizando o Geogebra, verificamos que seria pertinente a execução da pesquisa durante o período escolar para alunos da segunda série do Ensino Médio, pois estes conceitos são abordados na Proposta Curricular do Estado de São Paulo, no segundo semestre do ano letivo sob o Tema 2-Luz: fontes e características físicas e o Tema 3-Luz e cor.

Os alunos regularmente matriculados na instituição escolar foram divididos em três turmas denominadas de Turma $A, B$, e $C$.

Utilizamos o laboratório computacional da escola, constituído de 20 computadores, onde os alunos foram distribuídos de modo a ficarem de 2 ou 3 alunos em cada computador.

Quando fizeram somente atividades de simulação, os alunos permaneceram na sala de aula, onde acompanharam 0 desenvolvimento dos conceitos apresentados pelo professor, utilizando projetor, tela e computador.

A pesquisa foi dividida de forma a ser aplicada uma avaliação dos conceitos abordados em óptica geométrica, previamente ao uso do software Geogebra. Utilizando o tradicional método do uso de construções geométricas envolvidas na 
resolução de problemas, em um período de 12 semanas, em um total de 24 aulas, duas por semana abordando os seguintes conceitos:

\author{
-Princípios da Óptica Geométrica \\ -Reflexão, Reflexão em Espelhos Planos \\ -Reflexão em Espelhos Esféricos \\ -Refração e-Lentes
}

Nesse intervalo, durante as aulas, as turmas realizaram duas avaliações escritas compostas de cinco questões que abordaram os temas desenvolvidos nas aulas.

Em um período de três semanas ou seis aulas, os alunos foram levados ao laboratório computacional, onde então desenvolveram as atividades de construção dos problemas propostos, utilizando o software Geogebra, com orientação do professor.

Ao término desse período, os alunos realizaram novo teste avaliativo, de cinco questões que foram selecionadas a partir das dez primeiras questões aplicadas na avaliação prévia. Em seguida, os desempenhos e resultados foram analisados para verificarmos se houve ou não rendimento e aprendizagem através do uso do software Geogebra.

Dessa forma a pesquisa foi distribuída em períodos semanais representados na Tabela 4, a seguir:

Tabela 4 - Cronograma de desenvolvimento da pesquisa

\begin{tabular}{|l|c|}
\hline \multicolumn{1}{|c|}{ Atividade } & semana \\
\hline Princípios da Óptica Geométrica & $\mathrm{I}$ \\
\hline Reflexão, Espelhos Planos & $\mathrm{II}$ \\
\hline Espelhos esféricos & $\mathrm{III}$ \\
\hline Avaliação escrita I & $\mathrm{IV}$ \\
\hline Refração & $\mathrm{V}$ \\
\hline Reflexão Total & $\mathrm{VI}$ \\
\hline Lentes esféricas & $\mathrm{VII}$ \\
\hline Avaliação escrita II & $\mathrm{VIII}$ \\
\hline Construção com o Software & $\mathrm{IX}$ \\
\hline Construção com o Software & $\mathrm{X}$ \\
\hline Construção com o Software & $\mathrm{XI}$ \\
\hline Avaliação Final & $\mathrm{XII}$ \\
\hline
\end{tabular}




\section{3 - Geometria aplicada aos fenômenos ópticos}

A seguir, apresentamos alguns exemplos de conceitos geométricos, aplicados na resolução de problemas com fenômenos ópticos, entre eles o da Reflexão e Refração, que foram trabalhados em sala de aula com os alunos.

Dentre esses conceitos destacam-se:

- Soma dos ângulos internos de um triângulo;

Uma propriedade particular dos triângulos consiste em ter três ângulos que somados resultam em 180 graus.

Considerando um triângulo $A B C$ qualquer, podemos verificar essa afirmação:

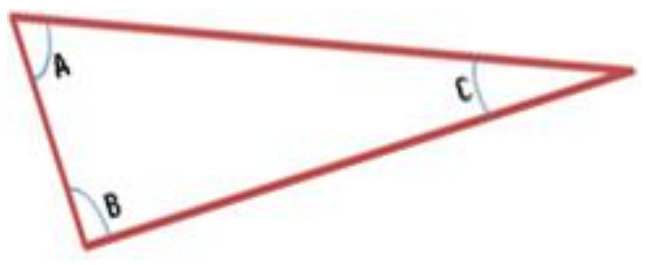

Considere ainda uma reta $\mathrm{r}$, passando pelo ponto $\mathrm{A}$ e paralela ao lado $\overline{B C}$ (essa reta sempre existe e é única). Como pode ser observado na figura abaixo, pode se obter os ângulos de modo que $x+y+A=180^{\circ}$.

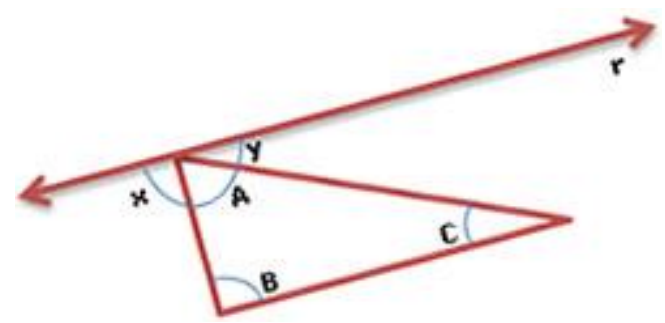

Sabendo que a reta $r$ e $\circ$ lado $(\overline{B C})$ são paralelos, os ângulos $\hat{y}$ e $\hat{C}$ são alternos internos e, portanto, são congruentes, isto significa que $\hat{y}=\hat{C}$. Pelo mesmo motivo, $\hat{x}=\hat{B}$. Assim, temos que:

$$
A+x+y=A+B+C=180^{\circ}
$$

Assim, é verdade que em todo triângulo a soma dos ângulos internos mede 180 graus. 
- Ângulos complementares e ângulos suplementares

Ângulos complementares são dois ângulos que somados totalizam $90^{\circ}$, isto é, um é complemento do outro. Ângulos suplementares são dois ângulos que somados são iguais a $180^{\circ}$, um é suplemento do outro.

- Razão e proporção;

Conceitualmente a razão do número a para o número $\mathbf{b}$, sendo $\mathbf{b} \neq \mathbf{0}$, é igual ao quociente de $\mathbf{a}$ por $\mathbf{b}$ que podemos representar das seguintes formas:

$$
a: b \text { ou } a / b
$$

A igualdade entre razões denomina-se proporção.

Os números $\mathbf{a}, \mathbf{b}, \mathbf{c}$ e $\mathbf{d}$, todos diferentes de zero, formam nesta ordem, uma proporção se, e somente se, a razão $\mathbf{a}: \mathbf{b}$ for igual à razão $\mathbf{c}: \mathbf{d}$.

Indicamos esta proporção por:

$$
\frac{a}{b}=\frac{c}{d}
$$

Chamamos aos termos $\mathbf{a}$ e $\mathbf{d}$ de extremos e aos termos $\mathbf{b}$ e $\mathbf{c}$ chamamos de meios.

Dessa forma a razão de 20 para 5 é igual a 4 pois $20: 5=4$.

A razão de 24 para 6 também é igual a 4 pois $24: 6=4$.

Podemos então afirmar que estas razões são iguais e que a igualdade abaixo representa uma proporção:

$$
\frac{20}{5}=\frac{24}{6}
$$

Lê-se a proporção acima da seguinte forma:

\section{"20 está para 5, assim como 24 está para 6".}

- Semelhança de triângulos;

Dois triângulos serão semelhantes se satisfizerem duas condições simultaneamente: se seus lados correspondentes possuírem medidas proporcionais e se os ângulos correspondentes forem iguais (congruentes).

Se invertermos a afirmação feita acima, teremos um fato verdadeiro: as condições são satisfeitas somente quando os triângulos são semelhantes. 
Observe a Figura 10, a seguir que representa dois triângulos:

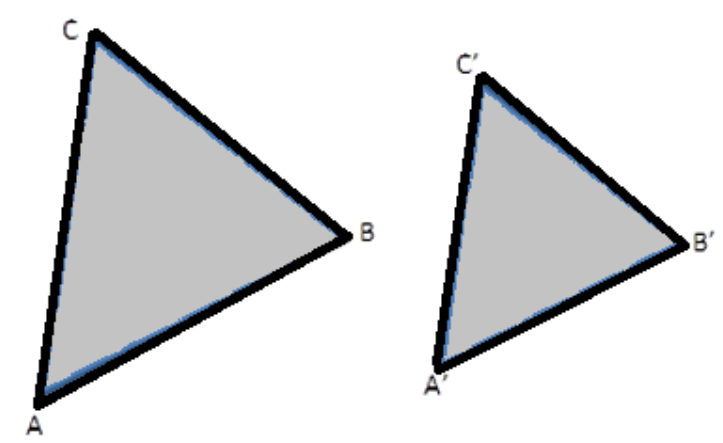

Figura 10- Triângulos semelhantes

Devemos determinar a correspondência dos vértices de cada triângulo, pois assim determinaremos a correspondência dos lados e dos ângulos entre estes dois triângulos.

Os vértices $A, B, C$ correspondem, respectivamente, aos vértices A', B', C'. Sendo assim, as razões de proporcionalidade entre os lados correspondentes.

$$
\frac{A^{\prime} B^{\prime}}{A B}=\frac{B^{\prime} C^{\prime}}{B C}=\frac{A^{\prime} C^{\prime}}{A C}=k
$$

Uma das condições é que todos os lados correspondentes possuam uma proporcionalidade, que chamaremos neste caso de k. Essa razão foi construída pela divisão de cada lado correspondente: veja que o lado A'B' do segundo triângulo corresponde ao lado $A B$ do primeiro triângulo. Por este fato, a divisão foi feita entre eles, e de mesmo modo com os outros lados.

Porém, apenas a condição de proporcionalidade dos lados não é suficiente para afirmarmos a semelhança entre os dois triângulos. É preciso que seus ângulos correspondentes sejam iguais.

$$
m(\hat{A})=m\left(\hat{A}^{\prime}\right), \quad m(\hat{B})=m\left(\hat{B}^{\prime}\right), \quad m(\hat{C})=m\left(C^{\prime}\right),
$$

Portanto, posemos indicar a semelhança destes triângulos da seguinte forma:

$$
\triangle A B C \sim \triangle A^{\prime} B^{\prime} C^{\prime} \Leftrightarrow\left\{\begin{array}{l}
\frac{A^{\prime} B^{\prime}}{A B}=\frac{B^{\prime} C^{\prime}}{B C}=\frac{A^{\prime} C^{\prime}}{A C}=k \\
e \\
m(\hat{A})=m\left(\hat{A}^{\prime}\right) ; m(\hat{B})=m\left(\hat{B}^{\prime}\right) ; m(\hat{C})=m\left(\hat{C}^{\prime}\right)
\end{array}\right\}
$$


- Teorema de Pitágoras.

Dentre muitos teoremas conhecidos, podemos considerar o Teorema de Pitágoras é uma das principais descobertas da Matemática, que descreve uma relação existente no triângulo retângulo. $O$ triângulo retângulo é identificado por possui um ângulo reto, ou seja, $90^{\circ}$, e é formado por dois catetos e a hipotenusa, que constitui o maior segmento do triângulo, localizada de forma oposta ao ângulo reto. Veja a Figura 11.

Catetos: b e c; Hipotenusa: a.

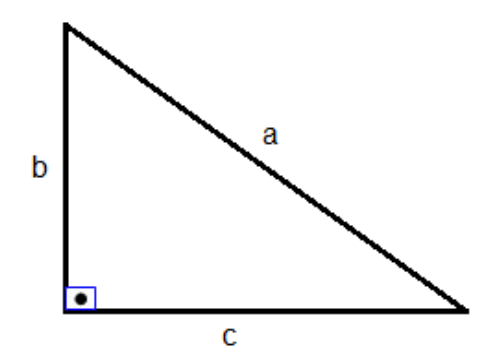

Figura 11-Triângulo retângulo

O Teorema diz que: "a soma dos quadrados dos catetos é igual ao quadrado da hipotenusa."

Logo: $\quad b^{2}+c^{2}=a^{2}$

- Equação dos pontos conjugados (Equação de Gauss) para espelhos esféricos e lentes delgadas e Aumento Linear Transversal

A equação de Gauss (Carl Friedrich Gauss) relaciona a distância do objeto p, a distância imagem p' e a distância focal f. É dada pela expressão:

$$
\frac{1}{f}=\frac{1}{p^{\prime}}+\frac{1}{p}
$$

Da Figura 12, observando os triângulos em destaque, obtemos a expressão do aumento linear transversal. Sendo $\mathbf{p}$ a distância do objeto a lente, $\mathbf{p}$ ' a distancia da imagem formada à lente, y representa o tamanho do objeto e y' o tamanho da imagem. Utiliza-se a convenção de sinais da seguinte forma:

$$
\begin{array}{ll}
y^{\prime}>0 \text { imagem direita ou direta } & p^{\prime}>0 \text { imagem real } \\
y^{\prime}<0 \text { imagem invertida } & p^{\prime}<0 \text { imagem virtual }
\end{array}
$$




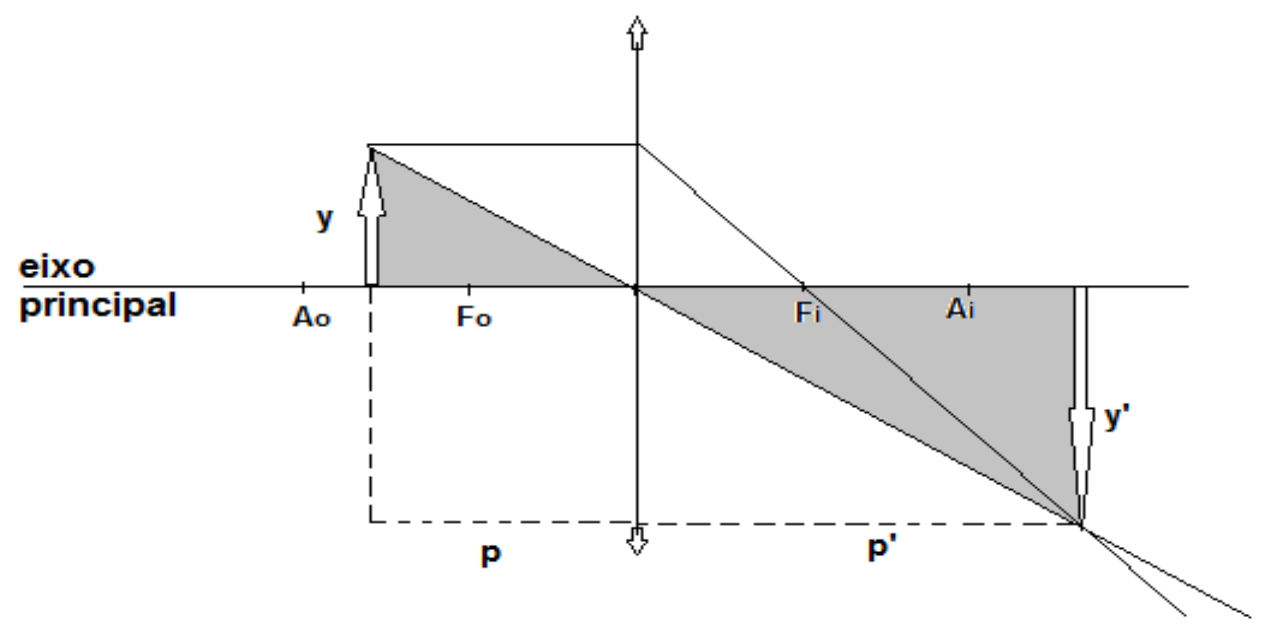

Figura 12- Determinação do aumento linear transversal-lente convergente.

Temos:

$$
\frac{-y^{\prime}}{y}=\frac{p^{\prime}}{p}=A
$$

Sendo A o aumento linear transversal.

Com essa expressão determinamos a equação de Gauss para os pontos conjugados. Por semelhança de triângulos indicados na Figura 13, temos:

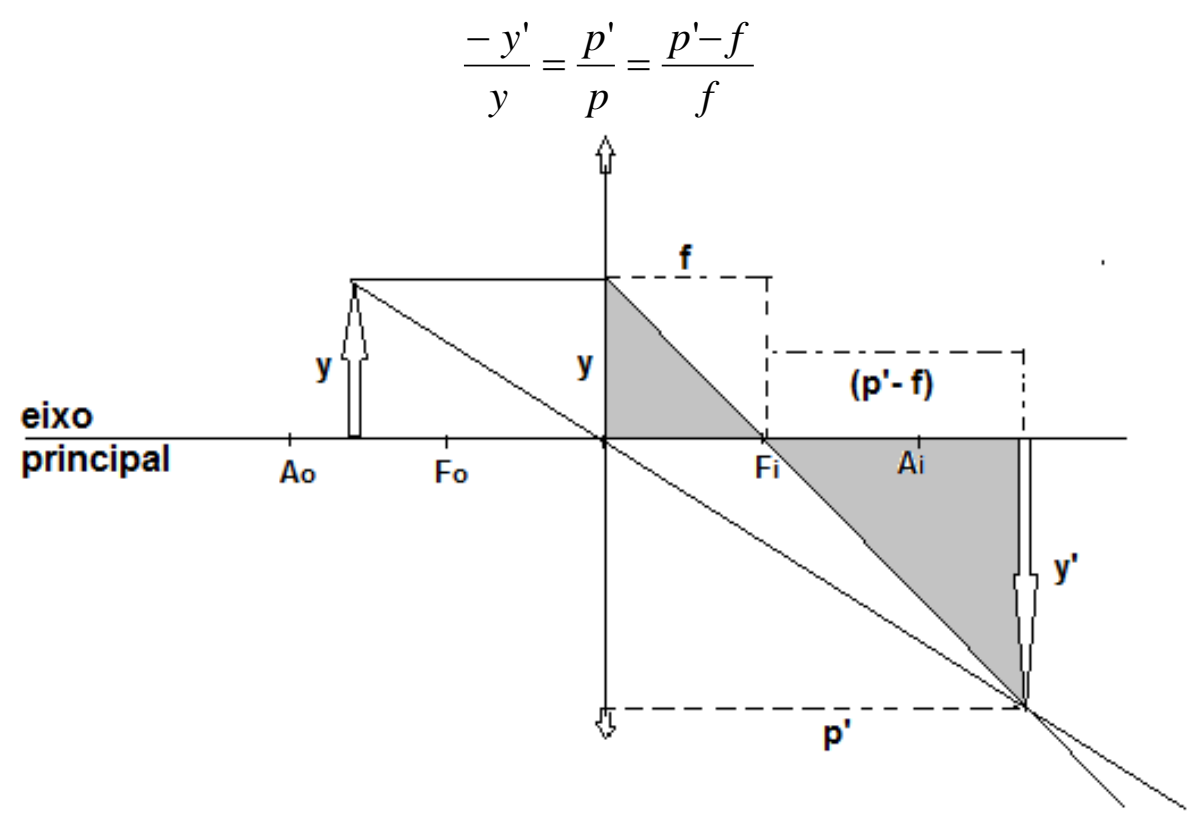

Figura 13-Determinação da Equação de Gauss

Desenvolvendo a última expressão, obtemos que: 


$$
p^{\prime} . f=p \cdot\left(p^{\prime}-f\right), \quad \text { e } \quad p^{\prime} . f=p \cdot p^{\prime}-p \cdot f
$$

Assim, dividindo os dois lados da equação por pp'f,

$$
\frac{p^{\prime} \cdot f}{p \cdot p^{\prime} \cdot f}=\frac{p \cdot p^{\prime}}{p \cdot p \cdot \cdot^{\prime} f}-\frac{p \cdot f}{p \cdot p^{\prime} \cdot f}
$$

Fazendo as devidas simplificações obtemos a Equação de Gauss para lentes e espelhos esféricos.

$$
\frac{1}{f}=\frac{1}{p^{\prime}}+\frac{1}{p}
$$

Apresentamos a seguir, uma série de exercícios que para serem resolvidos devemos aplicar os conceitos abordados anteriormente.

\section{Exemplo 2.1}

Um raio de luz $r$ incide sucessivamente em dois espelhos planos $E_{1}$ e $E_{2}$, que formam entre si um ângulo de $60^{\circ}$, conforme representado no esquema a seguir. Nesse esquema determinar o valor do ângulo $\alpha$.

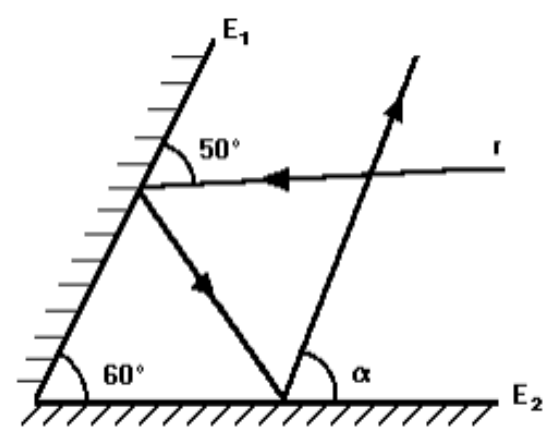

Pela Figura 14 a seguir, observamos que $\mathrm{i}_{1}$ e $\mathrm{i}_{2}$ são respectivamente os ângulos de reflexão nos espelhos $E_{1}$ e $E_{2}$. Dessa forma, podemos usar os conceitos de ângulos complementares, soma dos ângulos internos do triângulo e que a reta normal é perpendicular aos espelhos nos pontos de incidência $A$ e $B$, permitindo obter $x=50^{\circ}$ e $y=70^{\circ}$. Repetindo o raciocínio para $x$ obtemos que $y=\alpha=70^{\circ}$. 


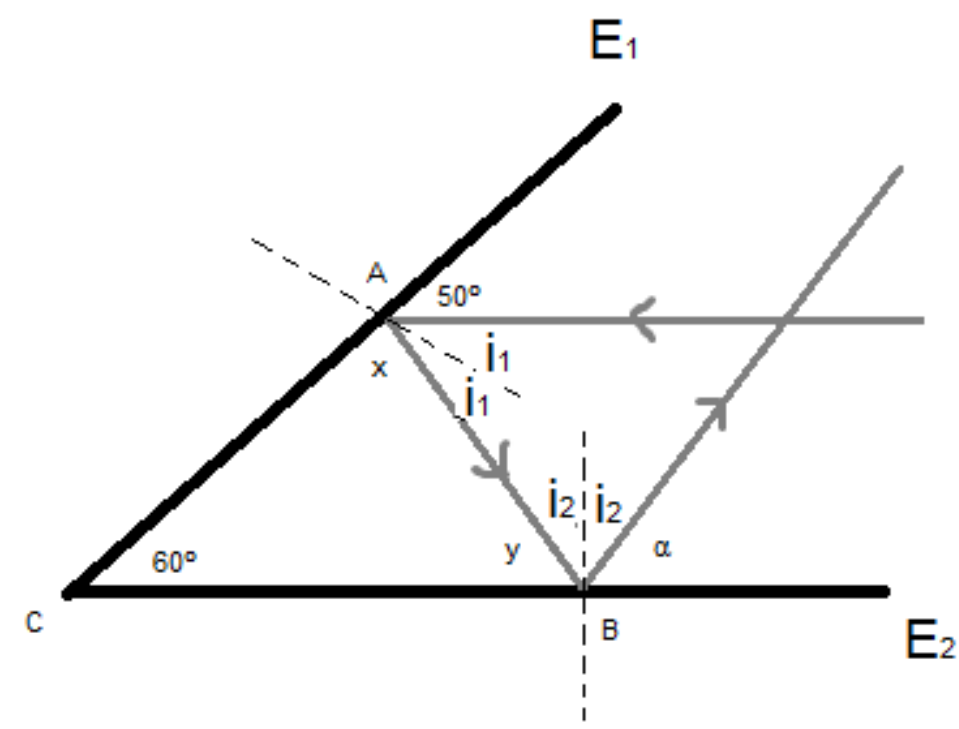

Figura 14 - Exemplo 2.1

\section{Exemplo 2.2}

A figura a seguir mostra um objeto A colocado a 5 metros de um espelho plano, e um observador no ponto $O$, que se encontra a 7 metros deste mesmo espelho. Um raio de luz que parte do ponto $A$ atinge o observador no ponto $O$ por reflexão no espelho. Determine a distância que a luz percorrerá, neste trajeto de $A$ para $O$.

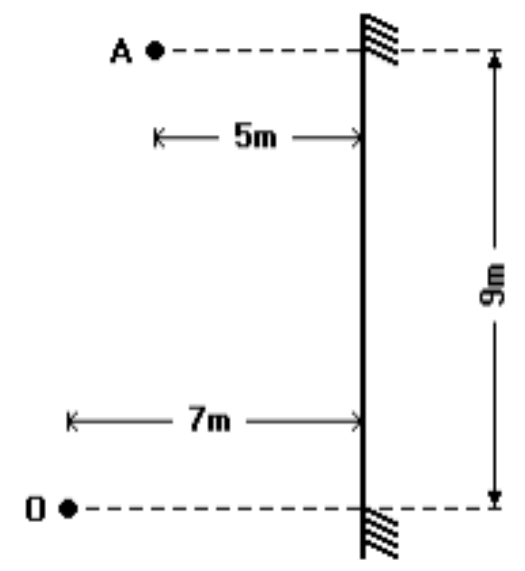

Podemos traçar a imagem do ponto $A$ que representamos por $A$ '. Em seguida representamos o raio refletido pelo espelho, traçamos o raio incidente, formando 0 triângulo $\triangle A^{\prime} \hat{O} B$, conforme sequência apresentada na Figura 15 . 

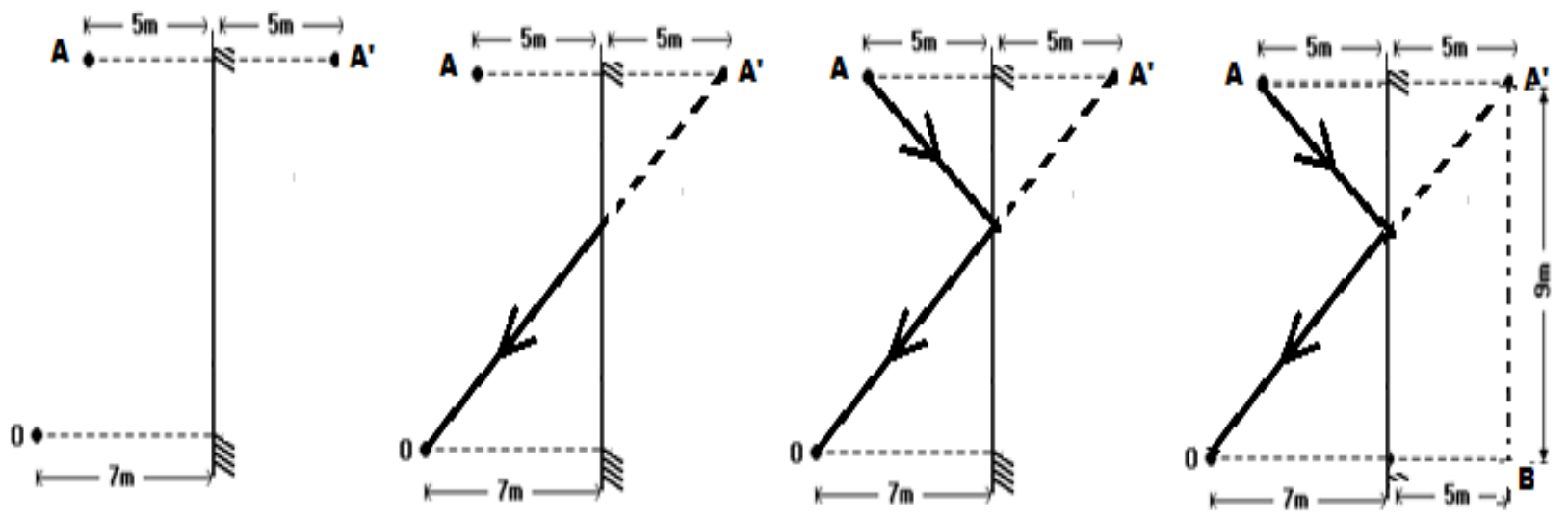

Figura 15 - Exemplo 2.2

Dessa forma, a distância percorrida pela luz corresponde ao segmento $\overline{A^{\prime} O}$, que podemos determinar usando o teorema de Pitágoras, resultando em 15 metros.

\section{Exemplo 2.3}

Num jogo de bilhar, um dos jogadores, encontra-se numa situação de sinuca, deseja marcar o ponto $\mathrm{C}$ sobre a borda da mesa de forma que a bola 1 descreva a trajetória mostrada na Figura 16 a seguir.

a) Determine a razão $\alpha / \beta$. Justifique a sua resposta.

b) Determine a que distância do ponto $A$ encontra-se o ponto $C$.

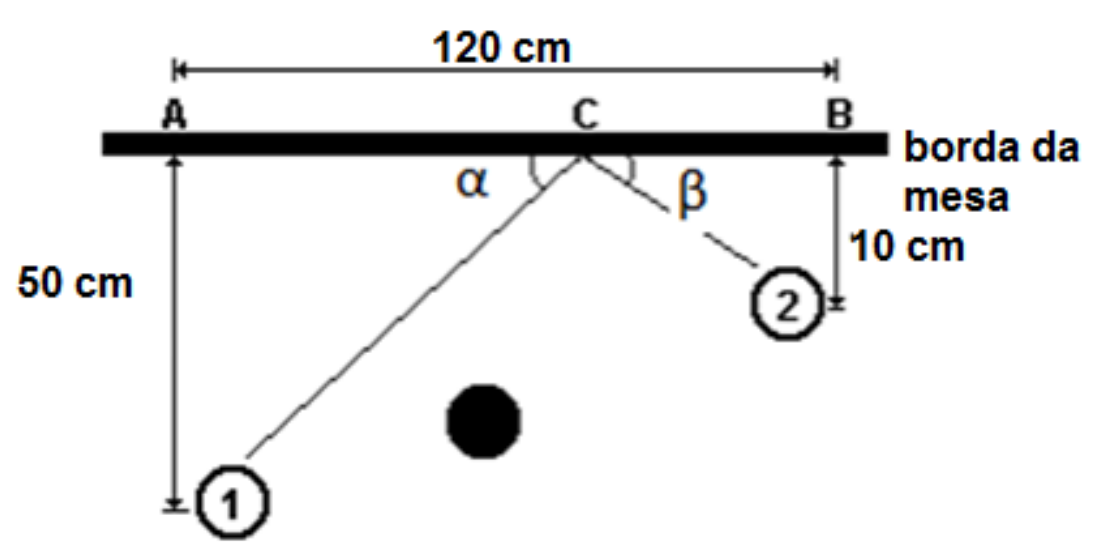

Figura 16-Exemplo 2.3

Para resolução do item a, verificamos que a razão $\alpha / \beta=1$, visto que pela $2^{\text {a }}$ lei da reflexão os ângulos $\alpha$ e $\beta$ serão iguais.

Para a solução do item b, partimos do conceito de semelhança de triângulos, utilizando a relação de proporcionalidade. Para $\mathrm{x}=\overline{B C}$, temos: 


$$
\overline{A C}=120-x .
$$

Assim,

$$
\frac{10}{50}=\frac{x}{120-x}
$$

ou seja:

$$
1200-10 x=50 x
$$

o que implica que

$$
x=20 \mathrm{~cm} \text {. }
$$

Assim, a distância de $\mathrm{C}$ em relação ao ponto A é de $100 \mathrm{~cm}$.

\section{Exemplo 2.4}

Uma pessoa deseja ver a imagem de seu corpo inteiro, dos pés $\boldsymbol{P}$ ao topo da cabeça $\boldsymbol{T}$, num espelho plano e retangular colocado na parede de seu quarto. Seja $\boldsymbol{H}$ é a altura total da pessoa e $\boldsymbol{h}$ é a altura dos olhos $O$ até $P$, determine 0 afastamento a da borda do espelho ao chão para que o espelho possa ter mínima altura $\boldsymbol{b}$ possível. Determine também o valor de $\boldsymbol{b}$.

A Figura 17 descreve o enunciado da questão e os raios de luz traçados:

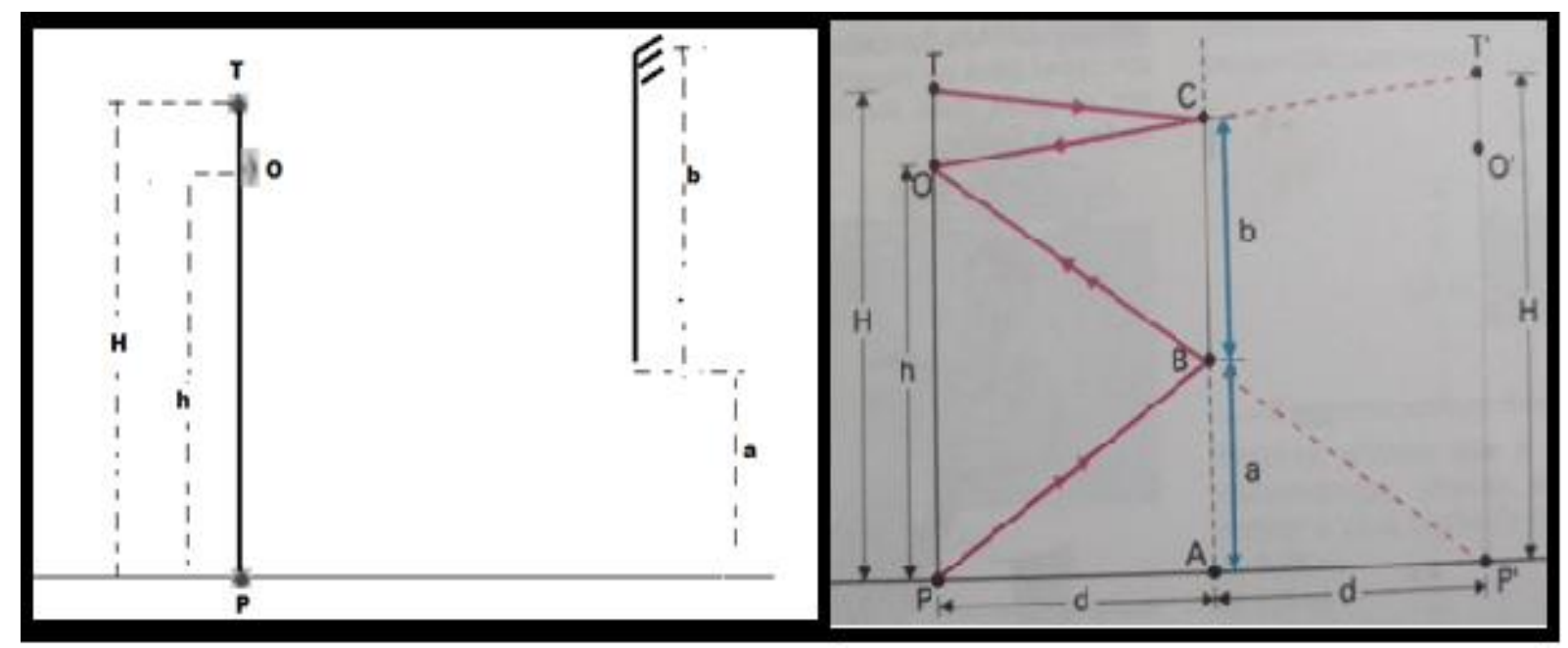

Figura 17 - Exemplo 2.4 
Inicialmente, usando simetria, traçamos a imagem da pessoa. Para que ela veja a imagem do seu corpo inteiro, é necessário que raios de luz provenientes de $\mathbf{T}$ e de $\mathbf{P}$ reflitam no espelho e cheguem aos seus olhos.

Da semelhança dos triângulos retângulos formados pelos pontos $B, P$ e $A$ e os pontos B, P' e A, temos:

$$
\frac{h}{a}=\frac{2 d}{d}
$$

de onde obtemos,

$$
a=\frac{h}{2} \text {. }
$$

Então, a borda inferior do espelho deve estar afastada de $\mathbf{h} / 2$ (metade da altura dos olhos) em relação ao chão, para que o espelho possa ter uma altura mínima b. Para determinarmos b, basta usarmos a semelhança dos triângulos

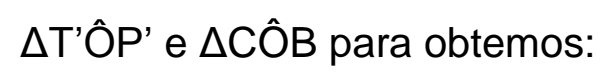

$$
\frac{H}{b}=\frac{2 d}{d}
$$

ou seja

$$
b=\frac{H}{2} .
$$

Então, respeitando o valor já determinado para a, a altura mínima do espelho é a metade da altura total da pessoa.

Os valores encontrados não dependem da distancia d da pessoa ao espelho. Se a pessoa se afastar do espelho, sua imagem parecerá menor porque será vista através de um ângulo visual menor, mas sua altura real continuará igual a $\mathrm{H}$.

\section{Exemplo 2.5}

Um objeto real é colocado sobre o eixo principal de um espelho esférico côncavo a $4 \mathrm{~cm}$ de seu vértice. A imagem conjugada desse objeto é real e está situada a $12 \mathrm{~cm}$ do vértice do espelho. Determinar:

a) O raio de curvatura do espelho.

b) O aumento linear transversal. 
Para resolução do item a, é necessário o uso da Equação dos Pontos Conjugados ou Equação de Gauss dada por:

$$
\frac{1}{f}=\frac{1}{p}+\frac{1}{p^{\prime}}
$$

onde $f$ é a distância focal, $p$ a distancia do objeto ao espelho e p' a distancia da imagem formada no espelho. Assim,

$$
\frac{1}{f}=\frac{1}{4}+\frac{1}{12}=\frac{1}{3}
$$

ou seja

$$
f=3 \mathrm{~cm} .
$$

Uma vez que o foco de uma lente ou espelho esférico representa o local de cruzamento dos raios refratados(lente) e refletidos(espelhos) quando incididos paralelamente ao eixo principal, e que por sua vez, essa distância representa o ponto médio do raio de curvatura da lente ou do espelho, representado por:

$$
f=\frac{R}{2},
$$

temos

$$
R=6 \mathrm{~cm}
$$

ou seja, o raio de curvatura $R$ do espelho possui comprimento igual a $6 \mathrm{~cm}$.

O Aumento Linear transversal $(A)$ corresponde a razão entre o tamanho da imagem e o tamanho do objeto podendo também ser definida pela razão entre a distância da imagem e a distância do objeto em relação ao espelho.

$$
A=\frac{y^{\prime}}{y}=-\frac{p^{\prime}}{p}=-\frac{12}{4}=-3,
$$

onde y' é o tamanho da imagem e y o tamanho do objeto. Por convenção o sinal negativo, representa o fato de a imagem ser invertida em relação ao objeto, pois toda imagem real é invertida em relação ao objeto. Em relação ao resultado, o valor encontrado, sendo um número inteiro, indica que a imagem é três vezes maior que o objeto.

\section{4-Avaliação.}

O processo de avaliação do aluno, sempre foi e sempre será tema de estudos, uma vez que, essa deve ser sempre contínua e revisada periodicamente a fim de replanejar os passos que conduz o aprendiz a uma aprendizagem 
significativa. Acreditamos que a avaliação deve incluir três dimensões pedagógicas, sendo essas: a Dimensão Diagnóstica, a Dimensão Formativa e a Dimensão Somativa que abordam as seguintes características, conforme (SANTOS,2005) ${ }^{[11]}$ :

- Integrar as estratégias de ensino utilizadas pelo professor;

- Constituir-se em um meio privilegiado de aprendizagem;

- $\quad$ Ter associado um processo de avaliação.

Segundo (LUCKESI,2004) ${ }^{[6]}$, a avaliação constitui um instrumento que nos fornece uma apresentação qualitativa, sobre os dados relevantes do processo de ensino aprendizagem, que auxilia o professor a tomar decisões sobre o seu trabalho. Dessa forma entendemos, que a Avaliação deve proporcionar as seguintes tarefas:

- Verificação através de coleta de dados sobre o aproveitamento dos alunos

- Qualificação ao comprovar resultados alcançados em relação aos objetivos

- $\quad$ Apreciação qualitativa dos resultados em relação ao desempenho esperado.

Dessa forma, concordamos com Libâneo (2004) $)^{[5]}$ que a avaliação deve cumprir pelo menos três funções: pedagógico-didática, diagnóstica e de controle.

As avaliações aplicadas se encontram nos anexos dessa pesquisa. 


\section{CAPÍTULO 3}

\section{O Desenvolvimento da Pesquisa}

As atividades possuem o propósito principal de apresentar a geometria atrelada aos fenômenos físicos em óptica geométrica através do uso do Software Geogebra.

Optamos por trabalhar com atividades que de um modo geral, apresentam grande complexidade e dificuldade de entendimento por parte dos alunos.

O principal objetivo é proporcionar através das atividades com o uso do Geogebra, maior motivação aos alunos, para que a aprendizagem significativa aconteça e o conhecimento seja construído a partir de uma temática.

A seguir apresentamos as atividades realizadas com os alunos, onde através do software, criamos simulações referentes aos enunciados das questões e em seguida determinamos as soluções para as atividades. Foram usados conceitos geométricos para determinar uma solução ou comprovar a proporcionalidade em alguns casos.

\section{1 - Sequência de atividades utilizando o Geogebra}

Atividade 1 - Verificação do princípio retilíneo da luz (1.3.1) através do problema da câmera escura.

Objetivos:

- Verificar a proporcionalidade entre o tamanho da imagem e do objeto bem como a distância do objeto em relação a espessura (profundidade) da câmera escura.

Atividade proposta: 
Um objeto luminoso de comprimento $\boldsymbol{0}$, de $5 \mathrm{~cm}$ de altura, está a uma distância $\boldsymbol{p}=$ $20 \mathrm{~cm}$, de uma câmara escura de profundidade $\boldsymbol{p}^{\prime}=10 \mathrm{~cm}$, como indicado na Figura 18. Calcular a altura i da imagem formada.

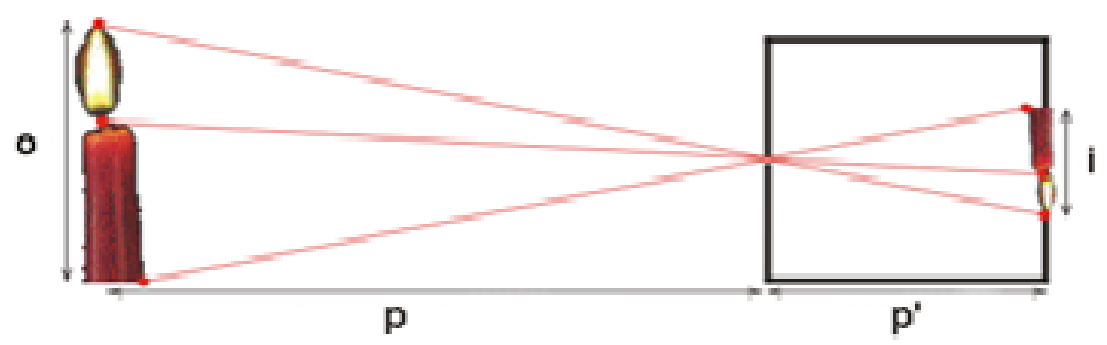

Figura 18 - Atividade 1

(http://www.geocities.ws/saladefisica8/optica/camara.html)

A figura 19 retrata a simulação realizada no Geogebra. Os alunos simularam a atividade sob a orientação do professor, em seguida verificaram a proporcionalidade entre o tamanho da imagem e do objeto bem como a distância do objeto em relação a espessura (profundidade) da câmera, após determinar os cálculos voltaram ao simulador para conferirem os resultados encontrados.

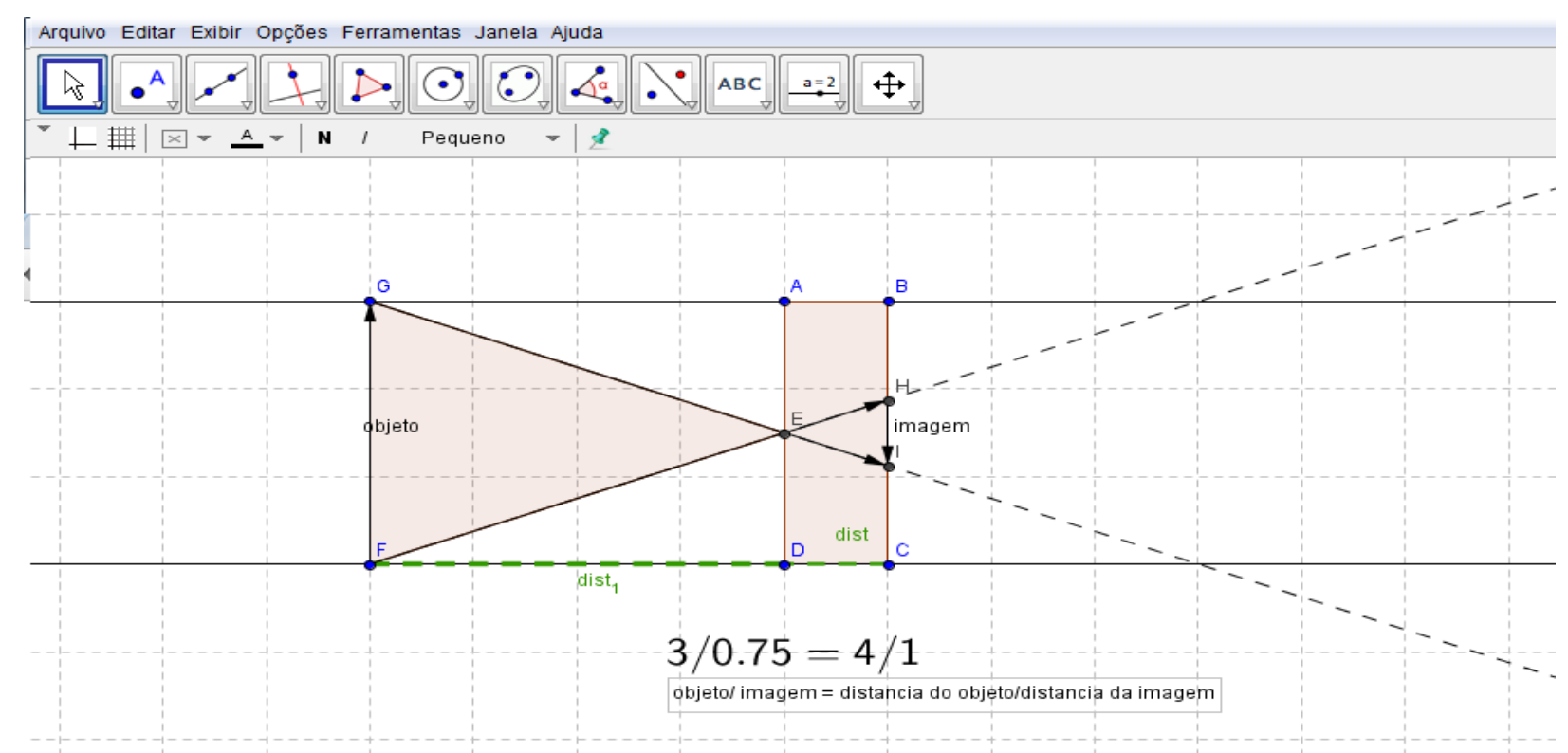

Figura 19 - Atividade 1 simulada no Geogebra

Para a resolução da atividade algebricamente, usamos o fato que os triângulos $\Delta G \hat{G E F ~ e ~} \Delta H \hat{E}$ l são semelhantes. Dessa forma temos: 


$$
\frac{\overline{F G}}{\overline{H I}}=\frac{\overline{F D}}{\overline{D C}} \text {, ou seja, } \frac{3}{0,75}=\frac{4}{1}
$$

Atividade 2: Verificação do princípio retilíneo da luz calculando a altura de um prédio.

Objetivos:

- Verificar a proporcionalidade entre a altura de um prédio e a altura de um menino através da sombra formada pelo prédio e a sombra formada pelo menino.

Atividade proposta:

Para determinar o tamanho de um prédio um menino mediu sua sombra e a sombra do prédio projetadas no chão, encontrando, respectivamente, $2 \mathrm{~m}$ e $32 \mathrm{~m}$. Qual a altura do prédio sabendo que o menino tem 1,5 $\mathrm{m}$ de altura?

A Figura 20 mostra a simulação do enunciado da atividade feita pelos alunos.

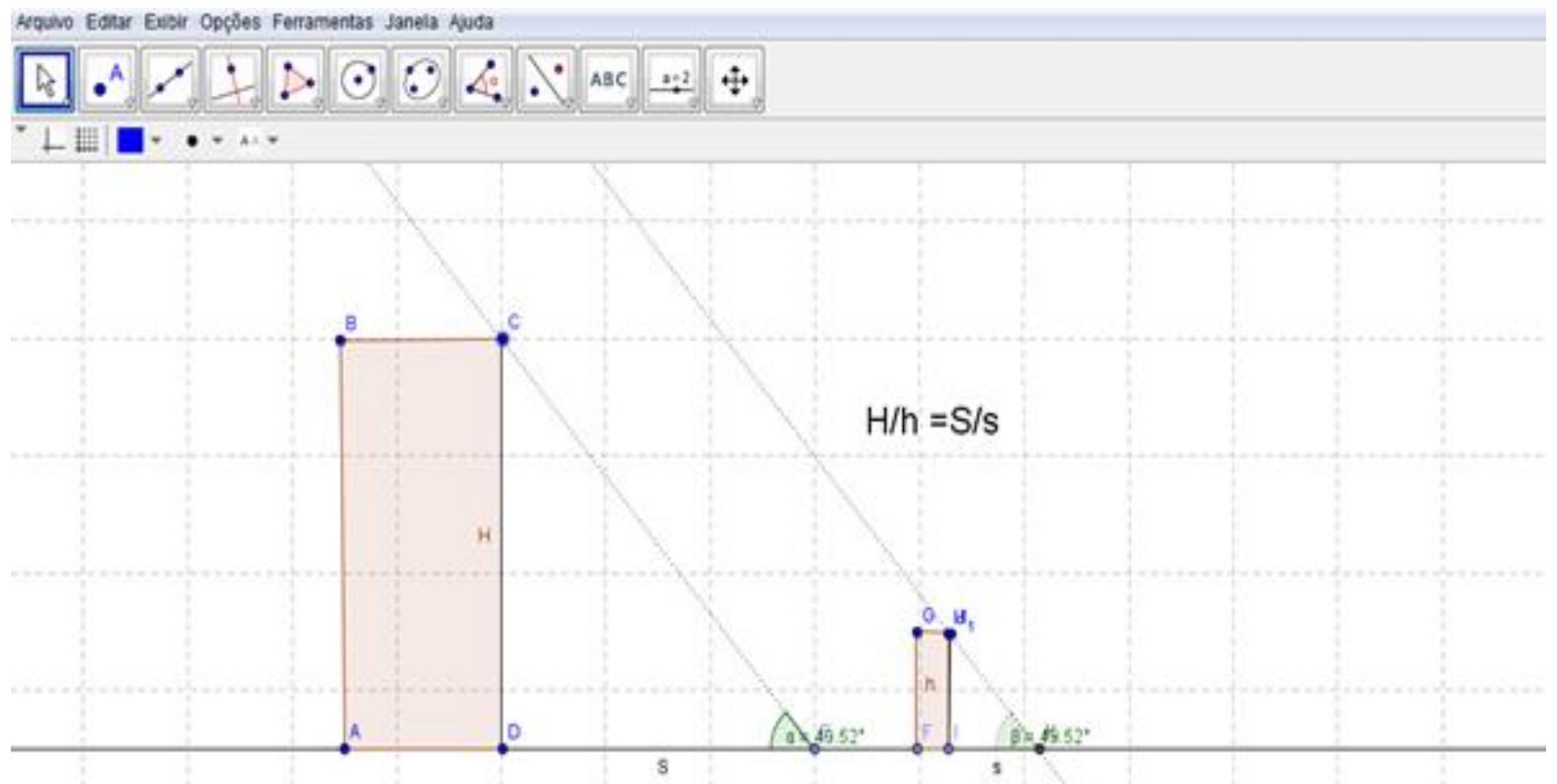

Figura 20 - Atividade 2 simulada no Geogebra

Como os triângulos $\Delta C \hat{E} D$ e $\Delta H \hat{K} I$ são semelhantes, temos:

$$
\frac{\overline{C D}}{\overline{H I}}=\frac{\overline{E D}}{\overline{K I}}, \text { ou seja, }
$$




$$
\frac{\overline{C D}}{1,5}=\frac{32}{2},
$$

que implica que

$$
\overline{C D}=24 m .
$$

Portanto, a altura do prédio é 24 metros.

\section{Atividade 3: Verificação do princípio retilíneo da luz através da sombra e penumbra formadas por uma fonte puntiforme e uma fonte extensa.}

Observação: Denomina-se fonte puntiforme, toda fonte que podemos desprezar o tamanho. Classificamos como fonte extensa as fontes cujo tamanho não pode ser desprezado.

Objetivos:

- Verificar que a fonte puntiforme forma apenas sombra e a fonte extensa forma sombra e penumbra. Calcular o tamanho da sombra e das penumbras formadas.

Atividade proposta:

Uma lâmpada de $10 \mathrm{~cm}$ de comprimento está fixa no teto de um quarto, cujo pé direito vale 2,8 m. Paralelamente a lâmpada e a $80 \mathrm{~cm}$ do piso, coloca-se uma haste metálica de $1 \mathrm{~m}$ de comprimento. Determine:

a) O comprimento de cada penumbra projetada no piso;

b) O comprimento da sombra projetada no piso;

c) Se a lâmpada fosse puntiforme qual o comprimento da sombra projetada no piso? 


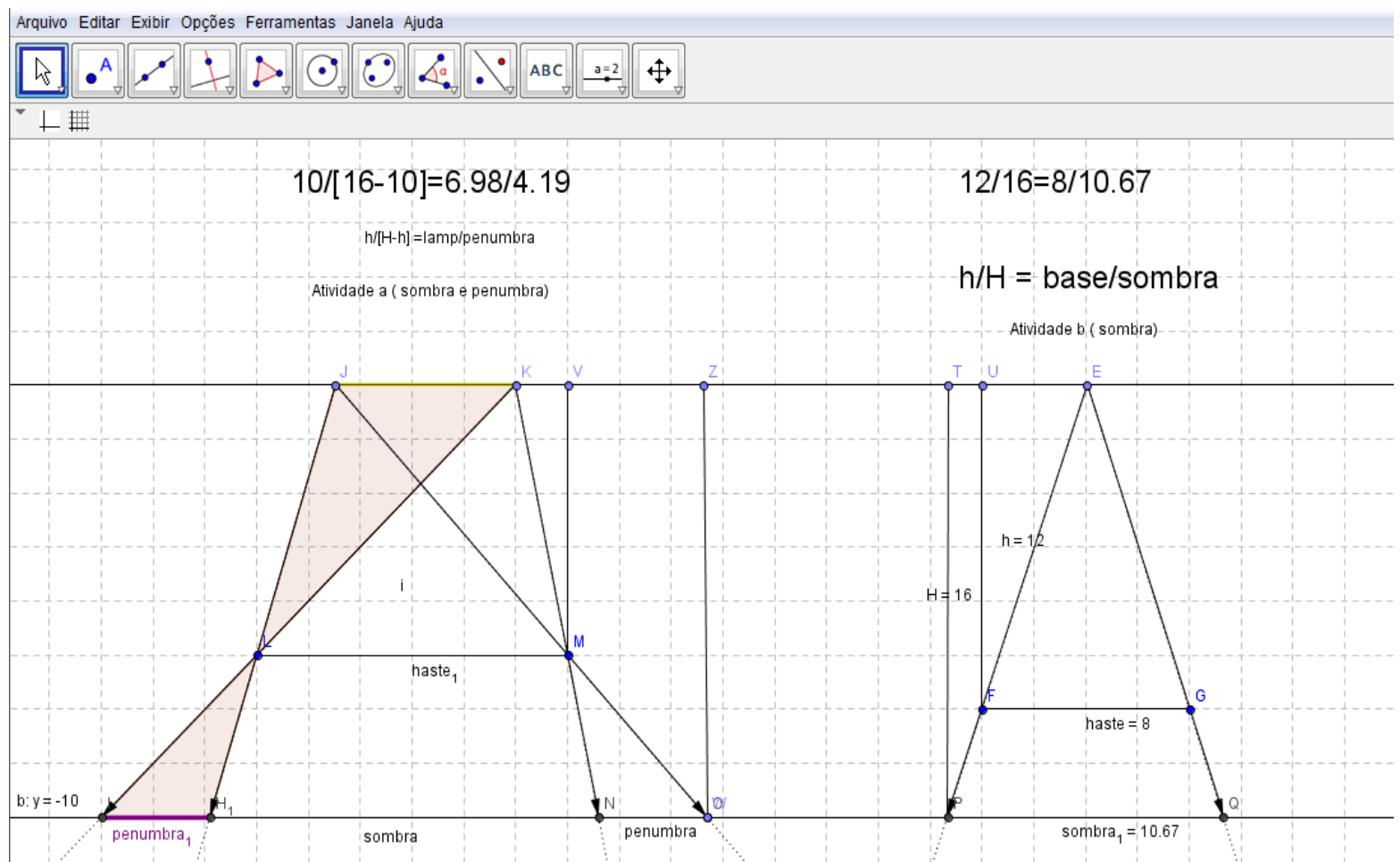

Figura 21 - Atividade 3 simulada no Geogebra

A simulação da esquerda na figura 21 representa uma fonte extensa que forma sombra e penumbra e a simulação da direita na mesma figura representa uma fonte puntiforme que forma apenas sombra, onde $\overline{J K}$, é o comprimento da lâmpada, $\overline{L M}$ o comprimento da haste metálica, os segmentos $\overline{I H_{1}}$ e $\overline{N O}$ representam as penumbras e $\overline{H_{1} N}$ representa a sombra formada no chão, na figura da esquerda.

Por semelhança dos triângulos $\Delta J \hat{L} K$ e $\Delta \hat{L} H_{1}$ temos:

$$
\frac{\overline{J K}}{\overline{I H_{1}}}=\frac{\overline{V M}}{\overline{Z O}-\overline{V M}},
$$

ou seja

$$
\frac{0,1}{x}=\frac{2}{0,8},
$$

Logo

$$
x=\frac{0,08}{2}=0,04 m .
$$

Assim é possível calcular a penumbra cujo valor é $x=0,04 \mathrm{~m}$ ou $\mathrm{x}=4 \mathrm{~cm}$.

Para o cálculo da sombra utiliza-se a semelhança entre os triângulos $\Delta L \hat{K} M$ 
e $\Delta I \hat{K} N$

ou seja

$$
\frac{\overline{L M}}{\overline{I H_{1}}+\overline{H_{1} N}}=\frac{\overline{V M}}{\overline{Z O}},
$$

de onde obtemos

$$
\frac{1}{0,04+y}=\frac{2}{2,8}
$$

$$
y=1,36 m \text {. }
$$

Logo o tamanho da sombra será $y=1,36$ metros.

$\mathrm{Na}$ figura da direita, do fato da fonte ser puntiforme, temos que não há formação de penumbra. O segmento $\overline{F G}$ representa o comprimento da haste, $\overline{U F}$ representa a distancia da haste até o teto, $\overline{T P}$ é o segmento que representa a distancia do chão ao teto e o segmento $\overline{P Q}$ representa o comprimento da sombra. Como os triângulos $\triangle F \hat{E} G$ e $\triangle P \hat{E} Q$ são semelhantes, temos:

$$
\frac{\overline{F G}}{\overline{P Q}}=\frac{\overline{U F}}{\overline{T P}}, \text { ou seja } \frac{1}{x}=\frac{2}{2,8},
$$

daí,

$$
x=\frac{2,8}{2}=1,4 m \text {. }
$$

Logo, o comprimento da sombra formada será 1,4 metros.

\section{Atividade 4: Verificação das leis da reflexão em espelhos planos.}

Objetivos:

- Verificar se o ângulo de incidência e o ângulo de reflexão são iguais.

-Determinar as características das imagens formadas em um espelho plano.

Atividade proposta:

(FUVEST) A figura a seguir, representa um objeto $A$ colocado a uma distância de 2,0 $\mathrm{m}$ de um espelho plano $S$, e uma lâmpada $L$ colocada à distância de 6,0 $\mathrm{m}$ do espelho.

a) Desenhe o raio emitido por $L$ e refletido em $S$ que atinge $A$. Explique a construção. 
b) Calcule a distância percorrida por esse raio.

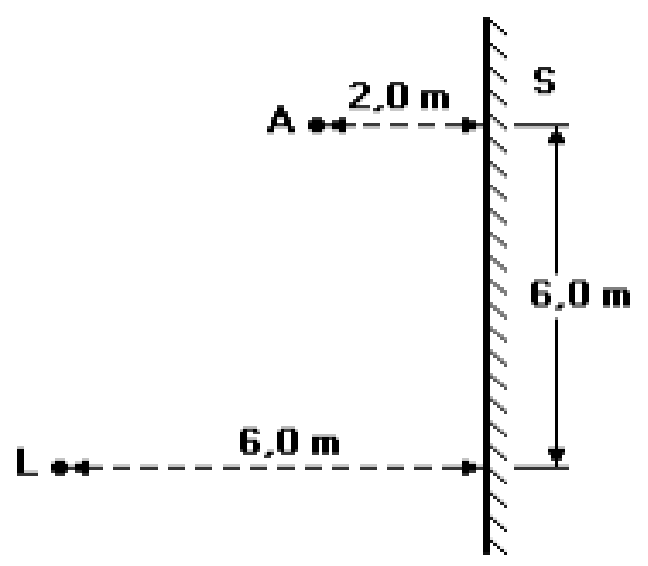

Figura 22 - Atividade 4

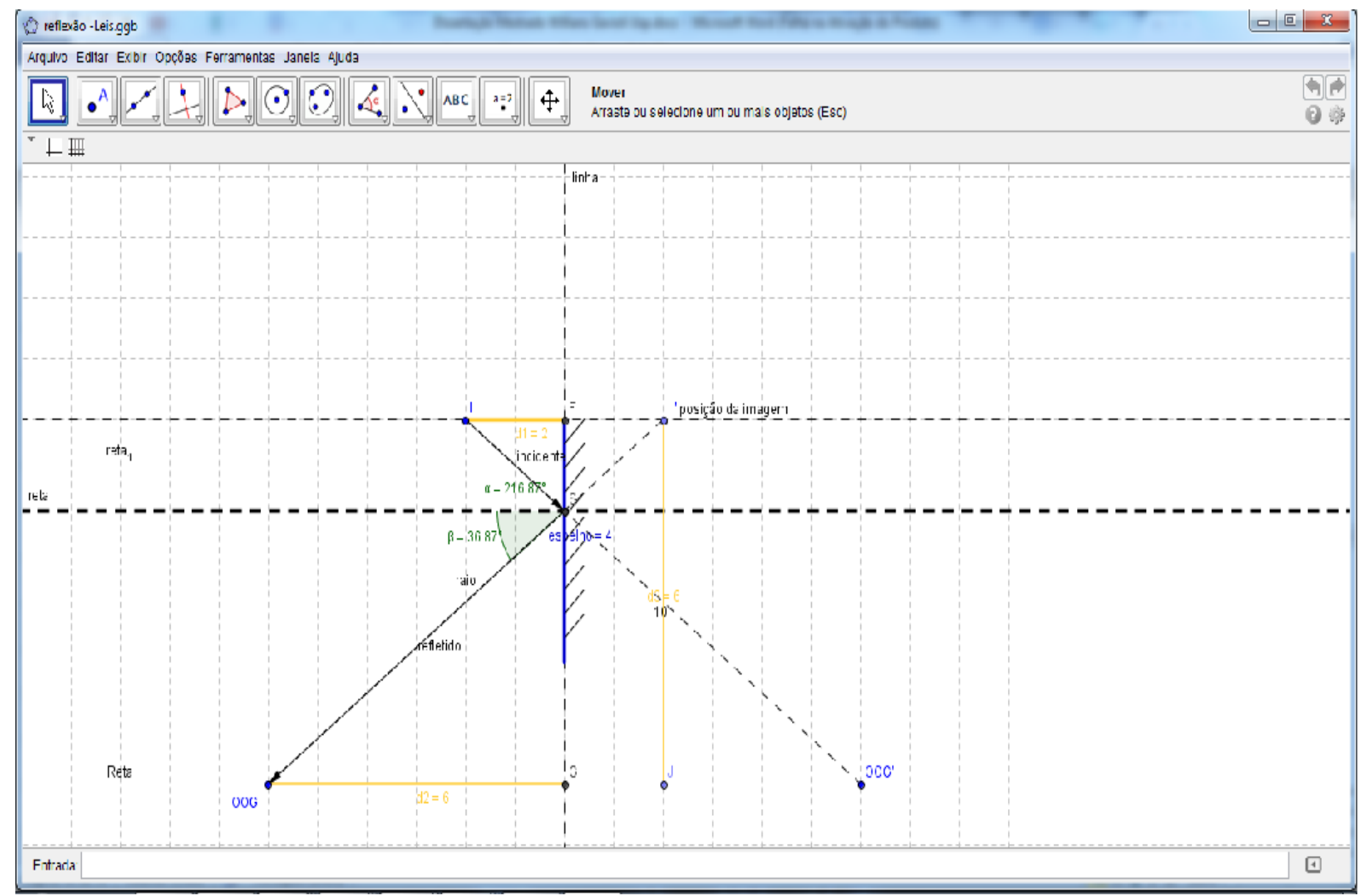

Figura 23 - Atividade 4 simulada no Geogebra

Para construir a trajetória da luz, primeiramente determina-se a posição da imagem $A^{\prime}$ por simetria, em seguida traça-se um seguimento que une $A^{\prime}$ com $L$, representando o raio refletido no espelho S, conforme Figura 23 e Figura 24. 


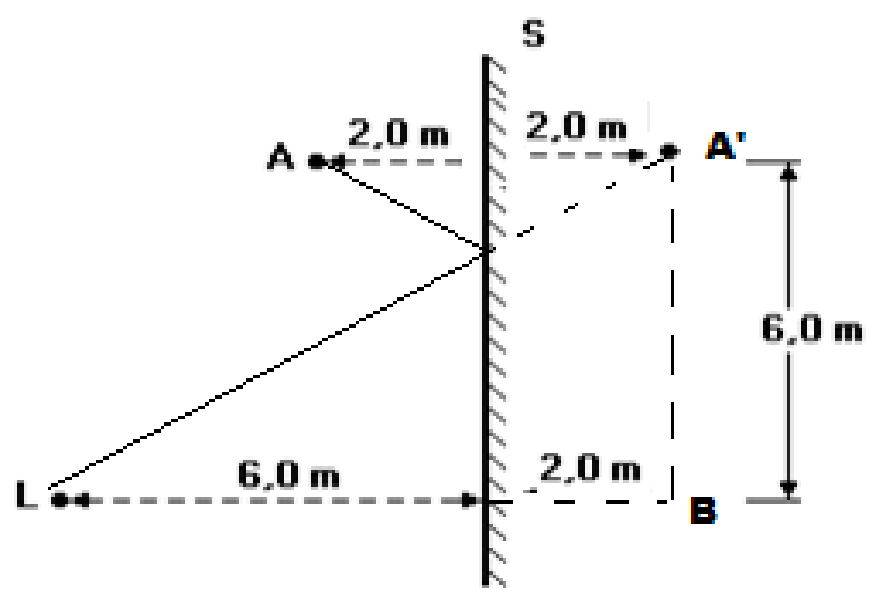

Figura 24- Obtenção do triângulo retângulo A'LB

O comprimento da trajetória percorrida pela luz é obtido aplicando o Teorema de Pitágoras no triângulo $\Delta A^{\prime} \hat{L} B$,

ou seja

$$
\overline{L A}^{2}={\overline{A^{\prime} B}}^{2}+\overline{L B}^{2}=6^{2}+8^{2}=36+64=100,
$$

$$
\overline{L A^{\prime}}=10 \mathrm{~m} .
$$

Assim, o comprimento da trajetória percorrida pelo raio de luz que sai de $L$, reflete no espelho e chega ao ponto A é de 10 metros.

\section{Atividade 5: Estudo dos espelhos esféricos}

Objetivos:

-Verificar a formação das imagens em espelhos côncavos e convexos

-Determinar o Aumento Linear transversal $y^{\prime} / y=-p^{\prime} / p$;

-Determinar a Equação dos Pontos conjugados ou equação de Gauss: 1/f =1/p'+1/p.

Atividade proposta:

(ITA-SP) Um objeto linear de altura $h$ está assentado perpendicularmente no eixo principal de um espelho esférico, a $15 \mathrm{~cm}$ de seu vértice. A imagem produzida é direita e tem altura de $h / 5$. Este espelho é:

a) Côncavo, de raio $15 \mathrm{~cm}$;

b) Côncavo, de raio $7,5 \mathrm{~cm}$;

c) Convexo, de raio $7,5 \mathrm{~cm}$; 
d) Convexo, de raio $15 \mathrm{~cm}$;

e) Convexo, de raio $10 \mathrm{~cm}$.

A atividade consiste em reproduzir todas as possibilidades de imagens formadas em espelhos côncavos e convexos determinando suas características em papel quadriculado e software. Em seguida verificar o uso da equação de Gauss para os pontos conjugados. Dessa forma a atividade simulada no Geogebra está representada na Figura 25.

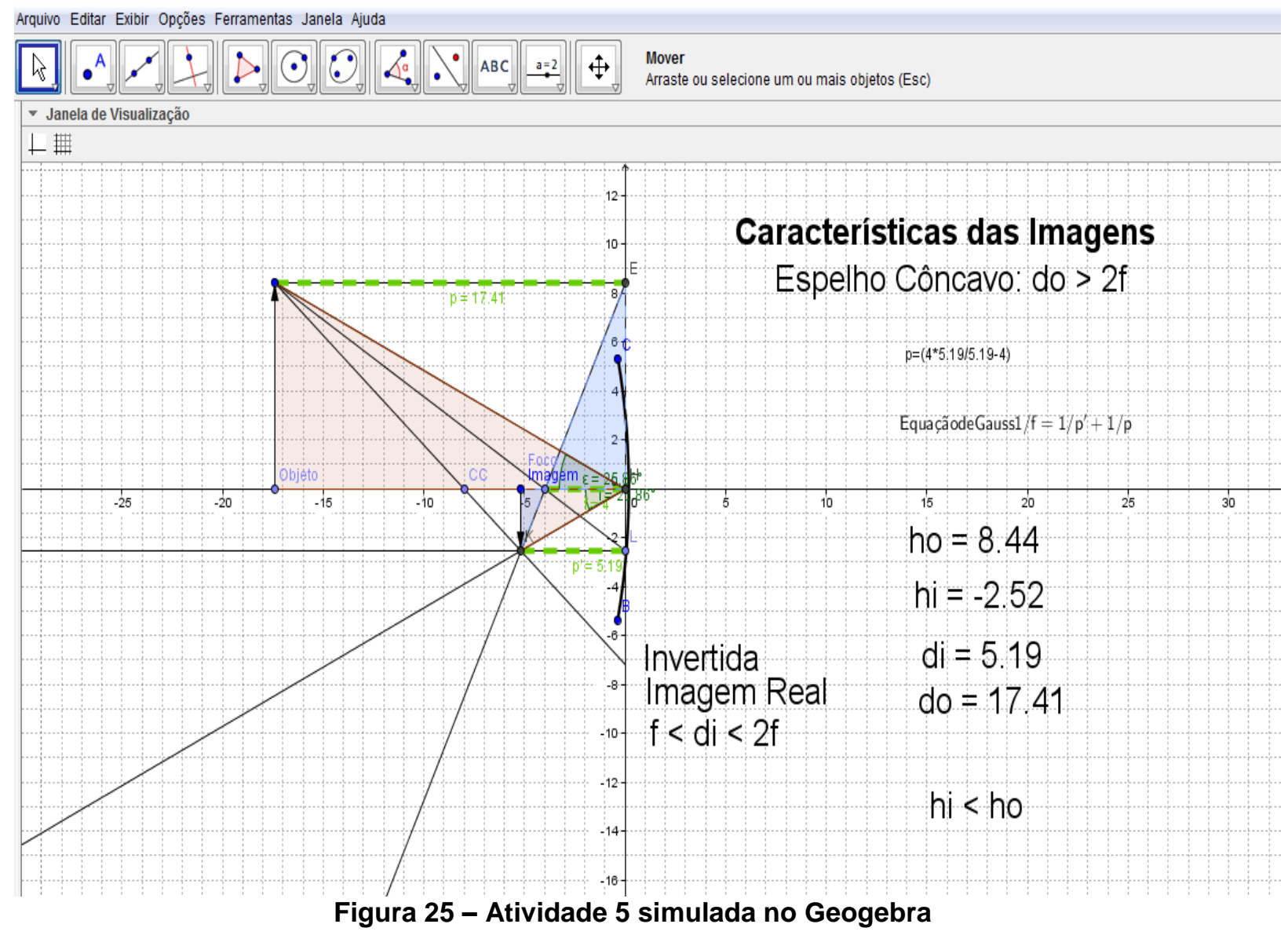

A Figura 26 mostra a representação gráfica das imagens formadas em espelhos esféricos, feita por um aluno. 


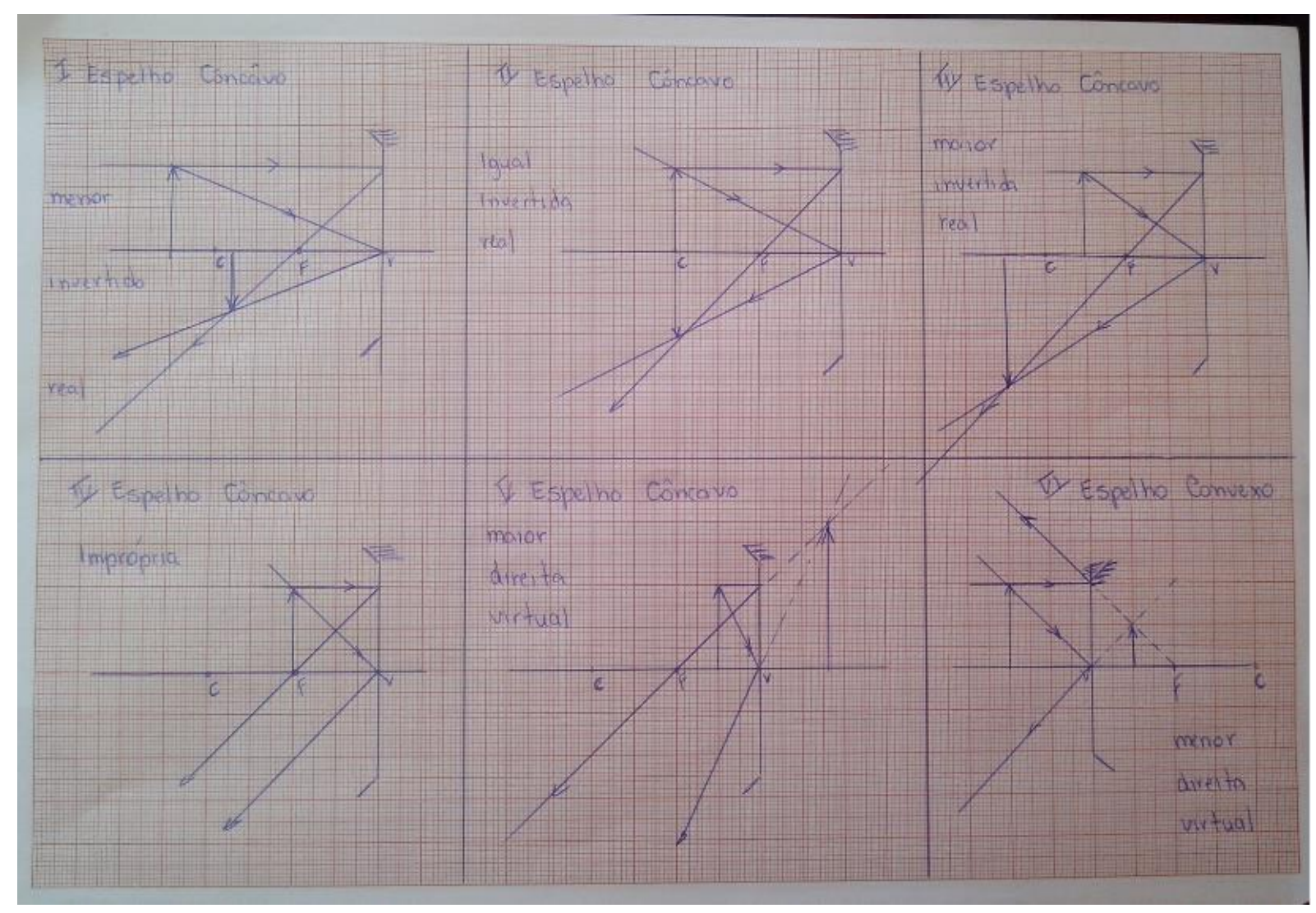

Figura 26 - Representação gráfica das imagens formadas em espelhos esféricos feitas por um aluno.

Seja $p=15 \mathrm{~cm}$ a distância do objeto ao espelho, $y=h$ o comprimento do objeto e $y^{\prime}=h / 5$ o tamanho da imagem. Se a imagem é direita (ou direta) o sinal de y' é positivo. Dessa forma, usando a equação do aumento linear $(A)$, temos

$$
A=\frac{y^{\prime}}{y}=-\frac{p^{\prime}}{p},
$$

ou seja

$$
\frac{h}{5 h}=-\frac{p^{\prime}}{15},
$$

o que implica que

$$
p^{\prime}=-3 \mathrm{~cm} .
$$

O sinal negativo de $p^{\prime}$ indica que a imagem é virtual.

Para calcular o raio precisamos calcular a distância focal $f$ através da equação de Gauss para os pontos conjugados:

$$
\frac{1}{f}=\frac{1}{p^{\prime}}+\frac{1}{p}=\frac{1}{-3}+\frac{1}{15}=-\frac{4}{15},
$$

ou seja, 


$$
f=-3,75 \mathrm{~cm} \text {. }
$$

Como $f=\frac{R}{2}$, obtemos

$$
R=7,5 \mathrm{~cm}
$$

O sinal negativo de $f$, ressaltamos que indica que o espelho é convexo. Assim, a resposta da atividade proposta é a alternativa c.

\section{Atividade 6: Estudo da refração - Lei de Snell/Descartes}

Há na história da Ciência diversas versões sobre quem determinou a Lei da Refração. Uns atribuem o feito ao matemático holandês Willebrord van Royen Snell (1580-1626), e outros, ao matemático francês René Descartes (1596-1620) de qualquer forma a relação encontrada foi sen (i) $/ \operatorname{sen}(r)=k$, onde k é constante, sendo i o ângulo de incidência e r o ângulo de refração.

Para essa atividade foi proposta duas perguntas:

1- O desvio do raio de luz na refração depende das refringências dos meios?

2- O desvio do raio de luz será sempre no sentido de se aproximar da reta normal?

Objetivo:

- Verificar as respostas às perguntas 1 e 2, bem como a ocorrência do fenômeno da Reflexão Total.

Atividade proposta:

A tabela a seguir mostra alguns valores dos senos dos ângulos de incidência e dos ângulos de refração do fenômeno chamado de refração.

a) Com o auxilio de uma calculadora, determine, com duas casas decimais, a relação sen (i) /sen(r) para cada caso. 
Tabela 5 - Relação de Snell

\begin{tabular}{|c|c|c|c|c|}
\hline $\mathrm{i}$ & $\mathrm{r}$ & $\operatorname{sen}(i)$ & $\operatorname{sen}(r)$ & $\operatorname{sen}(i) / \operatorname{sen}(r)$ \\
\hline $10^{\circ}$ & $7,5^{\circ}$ & 0,173 & 0,13 & \\
\hline $20^{\circ}$ & $14,9^{\circ}$ & 0,342 & 0,257 & \\
\hline $30^{\circ}$ & $22,0^{\circ}$ & 0,5 & 0,374 & \\
\hline $40^{\circ}$ & $28,8^{\circ}$ & 0,642 & 0,481 & \\
\hline $50^{\circ}$ & $35,1^{\circ}$ & 0,766 & 0,575 & \\
\hline
\end{tabular}

b) Sabe-se que, para a radiação, o índice de refração da água é 1,33, e do ar é 1 . Calcule a relação $n_{2} / n_{1}$, onde $n_{2}$ é o índice de refração do meio para qual a luz passa, e $n_{1}$ é o índice de refração do meio de onde a luz provém.

c) Compare os valores das relações sen (i) / sen (r) e $n_{2} / n_{1}$ e escreva o nome dessa relação.

Resolução,

$$
\frac{\operatorname{sen}(i)}{\operatorname{sen}(r)}=\frac{0,173}{0,130}=\frac{0,342}{0,257}=\frac{0,500}{0,347}=\frac{0,642}{0,481}=\frac{0,766}{0,575}=1,33
$$

\begin{tabular}{|c|c|c|c|c|}
\hline $\mathrm{i}$ & $\mathrm{r}$ & $\operatorname{sen}(i)$ & $\operatorname{sen}(r)$ & $\operatorname{sen}(i) / \operatorname{sen}(r)$ \\
\hline $10^{\circ}$ & $7,5^{\circ}$ & 0,173 & 0,13 & 1,33 \\
\hline $20^{\circ}$ & $14,9^{\circ}$ & 0,342 & 0,257 & 1,33 \\
\hline $30^{\circ}$ & $22,0^{\circ}$ & 0,5 & 0,374 & 1,33 \\
\hline $40^{\circ}$ & $28,8^{\circ}$ & 0,642 & 0,481 & 1,33 \\
\hline $50^{\circ}$ & $35,1^{\circ}$ & 0,766 & 0,575 & 1,33 \\
\hline
\end{tabular}

Para responder 0 item $b$ da atividade, primeiro iremos considerar que $a$ refração ocorra do ar para a água, assim, $n_{2}=1,33$ e $n_{1}=1$. Obtendo a relação $n_{2} / n_{1}$ $=1,33$. Comparando o valor encontrado para $n_{2} / n_{1}$ verificamos que é igual a sen (i)/ sen ( $r$ ), ou seja

$$
\frac{\operatorname{sen}(i)}{\operatorname{sen}(r)}=\frac{n_{2}}{n_{1}}=1,33
$$

A relação $\frac{\operatorname{sen}(i)}{\operatorname{sen}(r)}=\frac{n_{2}}{n_{1}}$ é chamada de Segunda Lei da Refração ou Lei de Snell. 
Baseado nos resultados obtidos, iremos responder as questões propostas no início da atividade.

1- O desvio do raio de luz na refração depende das refringências dos meios?

Refringência é o nome dado à dificuldade que o meio provoca à passagem da luz, dessa forma, quanto maior o índice de refração do meio, maior dificuldade a luz irá encontrar enquanto atravessa o meio, portanto sua velocidade será menor. Sendo o índice de refração absoluto do meio menor, maior será a velocidade de propagação da luz no meio. Observa-se que:

$$
n=\frac{c}{v},
$$

onde, n é o índice de refração, c a máxima velocidade da luz $(300.000 \mathrm{~km} / \mathrm{s})$ e v a velocidade de propagação no meio.

Por exemplo, no vácuo a velocidade da luz é de $300.000 \mathrm{~km} / \mathrm{s}$, calculando o índice de refração no vácuo teremos $c=300.000 \mathrm{~km} / \mathrm{s}$ e v vácuo $=300.000 \mathrm{~km} / \mathrm{s}$, logo

$$
n_{\text {vácuo }}=\frac{c}{v}=\frac{300.000}{300.000}=1 .
$$

Para determinar o índice de refração da água, teremos c $=300.000 \mathrm{~km} / \mathrm{s}$ e $\mathrm{V}_{\text {água }}=225.000 \mathrm{~km} / \mathrm{s}$, logo

$$
n_{\text {agua }}=\frac{c}{v}=\frac{300.000}{225.000}=1,33 .
$$

Assim, as refringências dos meios interferem na trajetória do raio de luz refratado.

2- O desvio do raio de luz será sempre no sentido de se aproximar da reta normal?

Pela Tabela 5 verifica-se que quando a luz atravessa do ar (menos refringente) para a água (mais refringente) o ângulo de refração $r$ será sempre menor que o ângulo de incidência, dizemos que o raio refratado tende a se aproximar da normal em relação a sua trajetória inicial.

Porém, se a luz refratar da água (mais refringente) para o ar (menos refringente),observamos que o ângulo de refração será maior que o ângulo de 
incidência. Assim, o raio refratado em relação a trajetória do raio incidente, tende a se afastar da reta normal. Portanto, nem sempre o raio de luz irá se aproximar da reta normal.

Em particular, quando o raio incidente forma um ângulo de $90^{\circ} \mathrm{com}$ a superfície de separação entre os meios, sendo sen $90^{\circ}=1$, verificamos que o raio refratado não sofre desvio, se mantendo perpendicular à superfície.

A Figura 27,demonstra a simulação realizada no Geogebra.

Arquivo Editar Exibir Opções Ferramentas Janela Ajuda

A

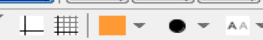

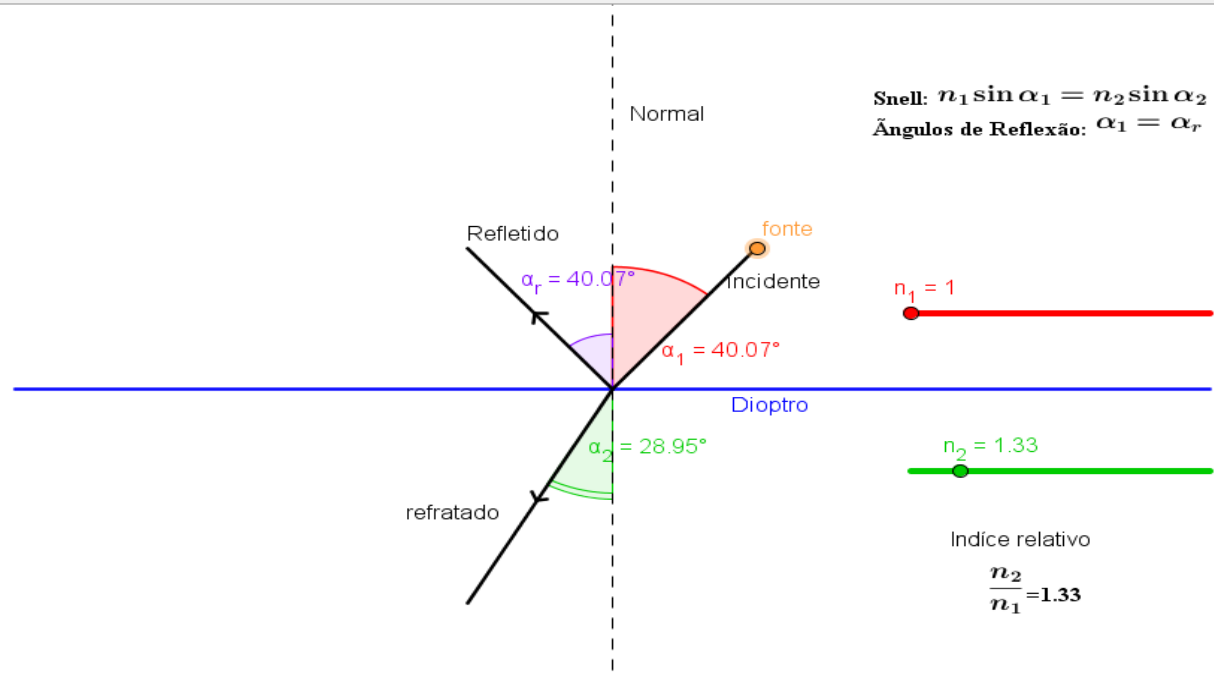

Figura 27 - Atividade 6 simulada no Geogebra

A simulação representada na Figura 28 a seguir, foi feita por um aluno fora do ambiente escolar.

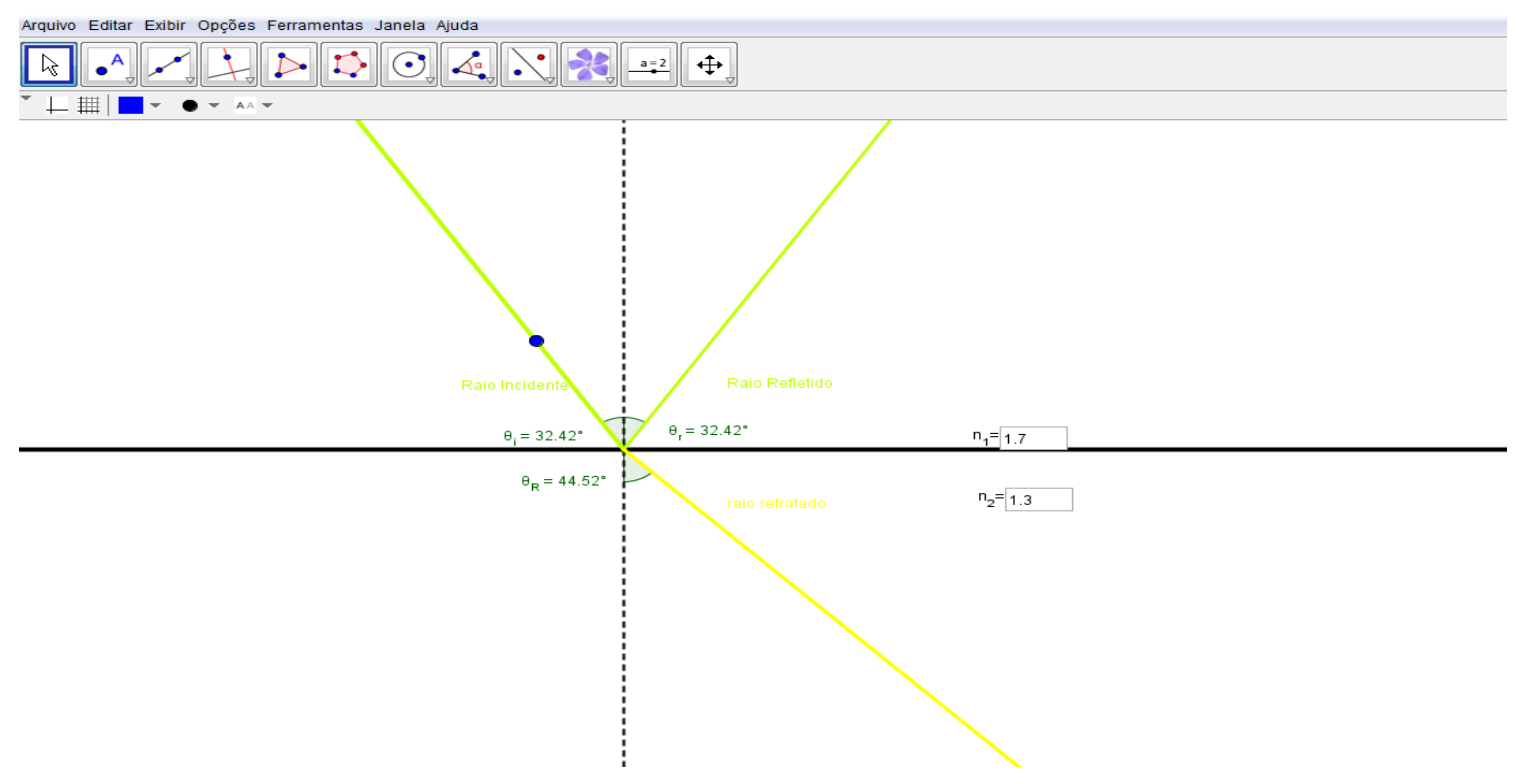

Figura 28 - Atividade 6 simulada por um aluno sem auxílio do professor 


\section{Atividade 7: Prisma óptico}

Objetivos:

- Verificar a relação entre os ângulos de desvios com o ângulo central do prisma, e a dependência do meio refringente.

Atividade proposta:

(FUVEST) Um pincel de luz branca incide perpendicularmente em uma das faces menores de um prisma, cuja secção principal, é um triângulo retângulo e isósceles. O prisma está imerso no ar e é constituído de um material transparente, que apresenta, para as sete radiações monocromáticas caracterizadas por sua cor, 0 índice de refração absoluto $n$, indicado na tabela abaixo:

Tabela 6 - Cores e índices de refração

\begin{tabular}{|c|c|}
\hline Cor & $\mathbf{n}$ \\
\hline violeta & 1,48 \\
\hline anil & 1,46 \\
\hline azul & 1,44 \\
\hline verde & 1,42 \\
\hline amarelo & 1,40 \\
\hline alaranjado & 1,39 \\
\hline vermelho & 1,36 \\
\hline
\end{tabular}

Observa-se que nem todas as radiações atingem um anteparo destinado a receber o espectro. Quais as cores recebidas no anteparo? Justifique sua resposta.

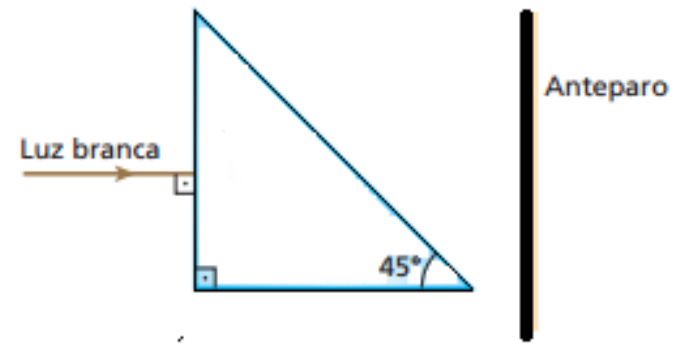

Figura 29 - Atividade 7

Ao incidir perpendicularmente na face do prisma, verificamos que não ocorre desvio do raio de luz dentro do prisma. Sendo o prisma um triangulo retângulo e isósceles o ângulo $\theta$ de incidência na hipotenusa do prisma é igual a $45^{\circ}$.

O fenômeno da Reflexão Total se caracteriza quando o ângulo de incidência atinge o seu limite para que ocorra refração, ou seja, quando sen (i) = sen (L), onde $\mathrm{L}$ é o ângulo limite para que se ocorra refração. Assim, quando o ângulo de 
incidência i é maior que o ângulo L o seno do ângulo i deverá ser maior que 1, que é uma contradição, logo o raio não sofre refração na face do prisma.

Para uma cor emergir do prisma e atingir o anteparo, o ângulo $\theta$ deve ser inferior ao ângulo-limite $L$. Se $\theta<L$, então sen $(\theta)<\operatorname{sen}(L)$, pois a função seno é crescente nesse intervalo.

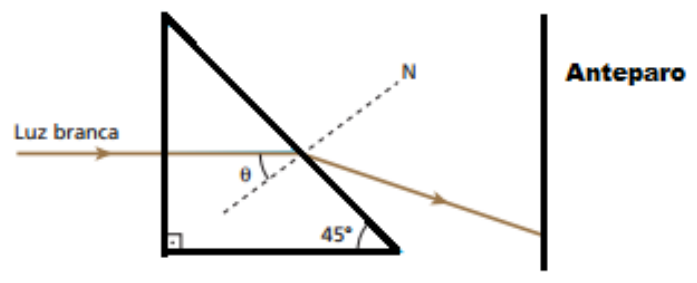

Então sen $(\theta)<n_{a r} / n_{\text {prisma }}$, ou seja, sen $45^{\circ}<1 / n_{\text {prisma }}$ o que implica que $n_{\text {prisma }}$ $<1,41$.

Essa condição é satisfeita para as cores Amarelo, Alaranjado e Vermelho, cujos índices são menores que 1,41.

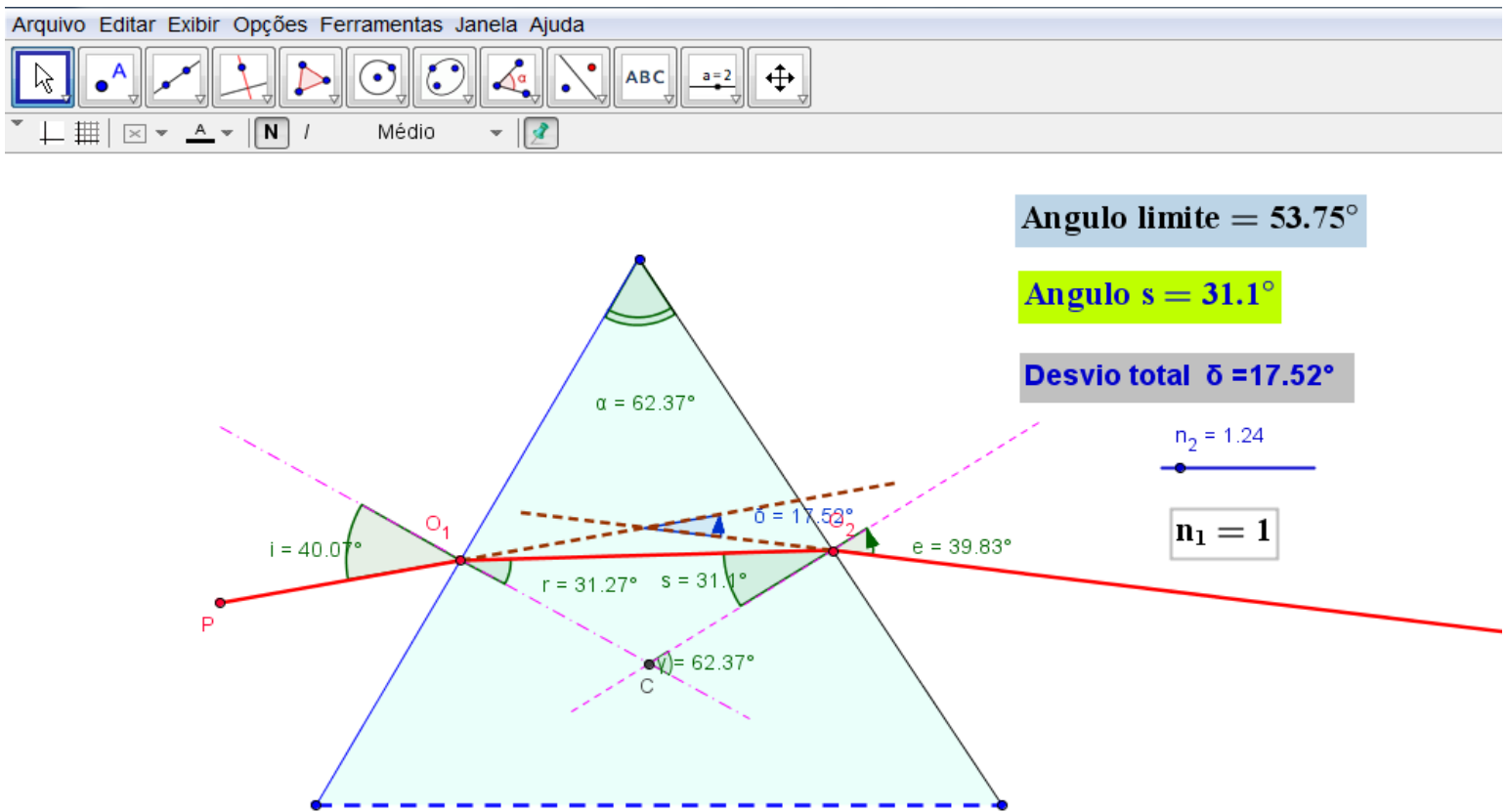

Figura 30 - Atividade 7 simulada com o Geogebra 
Atividade 8: Imagens formadas em lentes.

Objetivos:

- Verificar a formação de imagens em lentes esféricas e a validade da equação de Gauss para as lentes.

-Reproduzir todas as possibilidades de imagens formadas por lentes delgadas e suas características em papel quadriculado.

Atividade proposta:

(ITA) Um objeto tem altura $h_{0}=20 \mathrm{~cm}$ e está localizado a uma distância $d_{0}=30 \mathrm{~cm}$ de uma lente. Esse objeto produz uma imagem virtual de altura $h_{i}=4,0 \mathrm{~cm}$. $A$ distância da imagem à lente, a distância focal e o tipo da lente são, respectivamente:

a) $6,0 \mathrm{~cm} ; 7,5 \mathrm{~cm}$; convergente;

b) $1,7 \mathrm{~cm} ; 30 \mathrm{~cm}$; divergente;

c) $6,0 \mathrm{~cm} ;-7,5 \mathrm{~cm}$; divergente;

d) $6,0 \mathrm{~cm} ; 5,0 \mathrm{~cm}$; divergente;

e) 1,7 cm; -5,0 cm; convergente.

Antes de resolver a atividade proposta os alunos fizeram a simulação de todas as possibilidades de formação de imagens em lentes delgadas com o auxílio do software, onde uma delas está representada na Figura 26 a seguir:

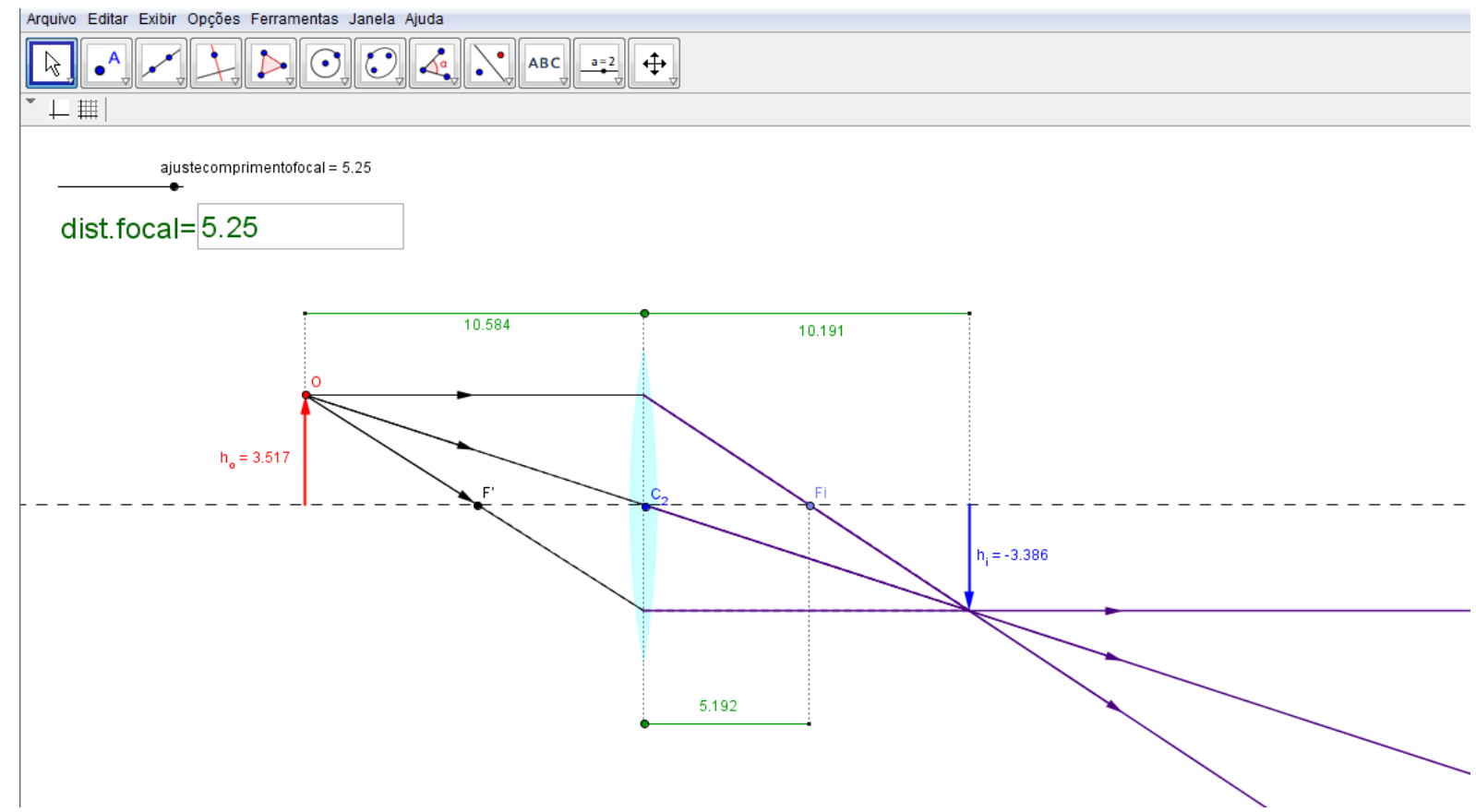

Figura 31 - Atividade 8 simulada no Geogebra 
A Figura 32, apresenta a representação gráfica das imagens formadas em lentes esféricas feitas por um aluno.

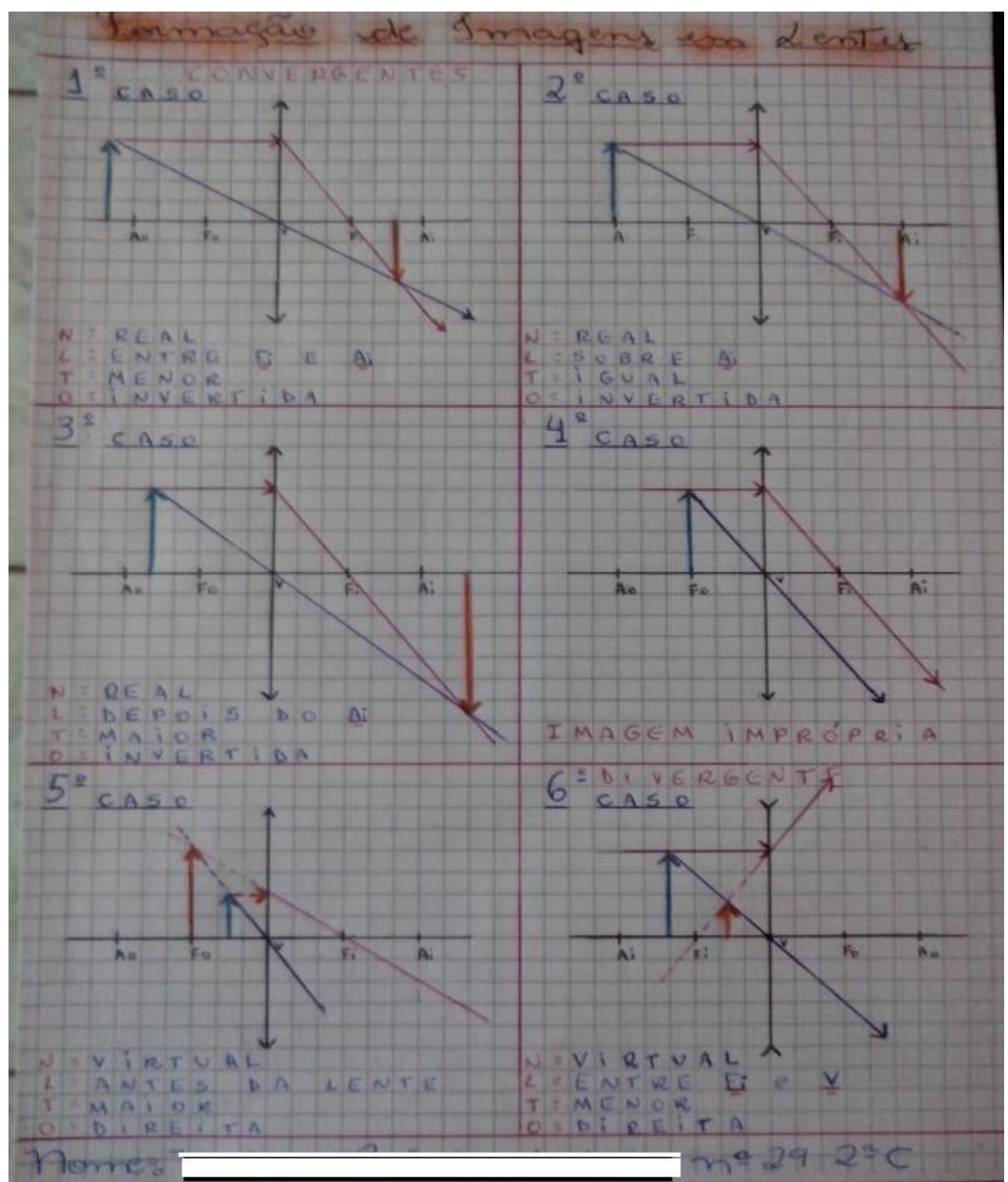

Figura 32 - Representação gráfica das imagens formadas em lentes esféricas

Sejam $\mathrm{p}=\mathrm{d}_{\mathrm{o}}=30 \mathrm{~cm}$ a distância do objeto à lente, $\mathrm{y}=\mathrm{h}_{\mathrm{o}}=20 \mathrm{~cm} \mathrm{o}$ comprimento do objeto e $y^{\prime}=h_{i}=4 \mathrm{~cm}$ o tamanho da imagem. Dessa forma, usando a equação do aumento linear $(A)$, temos:

$$
A=\frac{y^{\prime}}{y}=-\frac{p^{\prime}}{p},
$$

ou seja,

$$
\frac{4}{20}=-\frac{p^{\prime}}{30},
$$


obtendo

$$
p^{\prime}=-6 \mathrm{~cm} .
$$

O sinal negativo de $p$ ' indica que a imagem é virtual.

Calculando a distância focal $f$ através da equação de Gauss para os pontos conjugados temos,

$$
\frac{1}{f}=\frac{1}{p^{\prime}}+\frac{1}{p}=\frac{1}{-6}+\frac{1}{30}=\frac{-4}{30} .
$$

Portanto,

$$
f=-7,5 \mathrm{~cm} .
$$

O sinal negativo de f indica que a lente é divergente. Assim, a resposta da atividade proposta é a alternativa c.

\section{2 - Outras atividades}

Nessa pesquisa, apresentamos algumas atividades, que estão diretamente ligadas ao uso da geometria para suas resoluções. Também verificamos a grande possibilidade do uso do Software Geogebra, na composição de outras atividades que não exigem necessariamente cálculos, mas de modo geral, podem propiciar ainda mais a motivação e criatividade dos alunos, como por exemplo, a construção de eclipses, estudo do campo visual, formação de arco íris, a trajetória de um raio de luz dentro de uma gota de água, etc...

Os recursos oferecidos pelo Geogebra proporcionam grande aplicabilidade e acessibilidade por parte do professor e alunos, podendo ser obtido de forma gratuita. O software apresenta interface motivadora e atrativa, permitindo ao aluno testar hipóteses. Ele proporciona a criação de um cenário de investigação como ambiente de aprendizagem. Assim, é possível criar diversas atividades e reproduzir diversas situações problemas de forma interdisciplinar. 


\section{CAPÍTULO 4}

\section{Análise de Resultados}

Nesse capítulo apresentamos resultados obtidos através das avaliações e observações realizadas durante as aulas em que foram utilizadas o software Geogebra.

Dessa forma, faremos uma discussão baseada nos elementos que surgiram a partir dos dados coletados e assim sugerimos novas possibilidades que podem contribuir para melhoria do processo ensino/aprendizagem para que os alunos possam atingir total compreensão do assunto proposto. Entendemos que a conclusão de uma pesquisa nos remete um referencial para novas discussões e novos segmentos de pesquisa.

\section{1 - Atividades utilizadas antes do uso do Geogebra e resultados}

Ao iniciar essa pesquisa tínhamos em mente a necessidade de repensar em novas práticas metodológicas, que de algum modo despertasse a atenção e motivação dos alunos.

É certo que os currículos precisam ser repensados bem como a formação dos novos professores conforme indicam (D'AMBRÓSIO,2001) $)^{[3]}$, e (CURY,2001) ${ }^{[2]}$.Os currículos devem atender as exigências de uma real aprendizagem nos dias atuais, de modo que o professor, possa promover a aprendizagem significativa sendo capaz de construir seu próprio conhecimento, de maneira que este esteja integrado a sociedade e aliado com as novas tecnologias digitais.

Embora o uso de recursos computacionais tenham aumentado no ambiente escolar os resultados positivos caminham a passos pequenos, sobretudo em resultados de avaliação, onde demostram índices preocupantes.

Por isso a avaliação diagnóstica apresentou em sua grande maioria, um déficit muito grande antes da realização de atividades que envolveram o uso do software Geogebra com alunos do Ensino Médio. 
Dessa forma, ao trabalhar os conteúdos sem o uso do Geogebra observamos certa inércia no quesito motivação, atenção e interesse por parte dos alunos. E o resultado das avaliações não foram satisfatórios.

As avaliações (ANEXO I e II) que foram aplicadas durante o período que antecede o uso do Geogebra, foram compostas de cinco questões cada, sobre os fenômenos ópticos, seguindo o planejamento da pesquisa. As avaliações foram aplicadas nas três turmas da segunda série do Ensino Médio perfazendo um total de 84 alunos. As Tabelas 7, 8 e 9 apresentam os resultados das avaliações.

Tabela 7 - Notas dos alunos da turma $A$ antes do uso do Geogebra

\begin{tabular}{|c|c|c|c|c|c|c|}
\hline & \multicolumn{7}{|c|}{ Turma $A$} \\
\hline & $\begin{array}{c}\text { Número de } \\
\text { Notunos 1a }\end{array}$ & $\%$ & $\%$ Acumulada & $\begin{array}{c}\text { Numero de } \\
\text { Alunos 2 }\end{array}$ & $\%$ & $\begin{array}{c}\% \\
\text { Acumulada }\end{array}$ \\
\hline $0 \mathrm{a}<1$ & 1 & 3,23 & 3,23 & - & 0,00 & 0,00 \\
\hline $1 \mathrm{a}<2$ & 3 & 9,68 & 12,90 & 3 & 9,68 & 9,68 \\
\hline $2 \mathrm{a}<3$ & 3 & 9,68 & 22,58 & 5 & 16,13 & 25,81 \\
\hline $3 \mathrm{a}<4$ & 7 & 22,58 & 45,16 & 9 & 29,03 & 54,84 \\
\hline $4 \mathrm{a}<5$ & 7 & 22,58 & 67,74 & 6 & 19,35 & 74,19 \\
\hline $5 \mathrm{a}<6$ & 6 & 19,35 & 87,10 & 5 & 16,13 & 90,32 \\
\hline $6 \mathrm{a}<7$ & 2 & 6,45 & 93,55 & 1 & 3,23 & 93,55 \\
\hline $7 \mathrm{a}<8$ & 2 & 6,45 & 100,00 & 1 & 3,23 & 96,77 \\
\hline $8 \mathrm{a}<9$ & - & 0,00 & 0,00 & 1 & 3,23 & 100,00 \\
\hline $9 \mathrm{a}<10$ & - & 0,00 & 0,00 & - & 0,00 & 0,00 \\
\hline Total & 31 & 100,00 & - & 31 & 100,00 & - \\
\hline
\end{tabular}

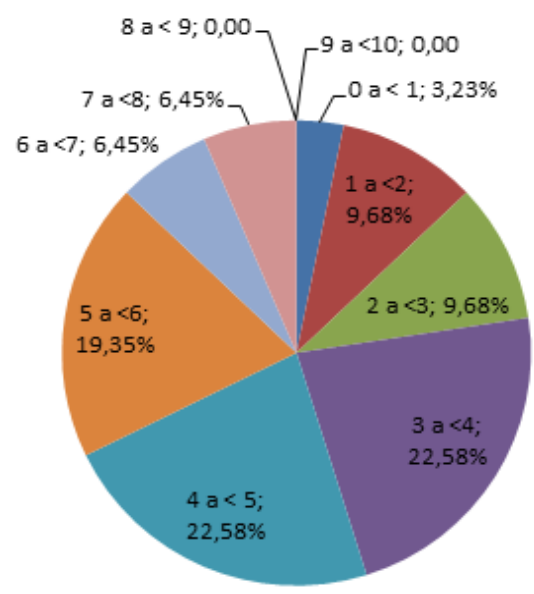

Rendimento turma A na primeira avaliação sem o uso do software.

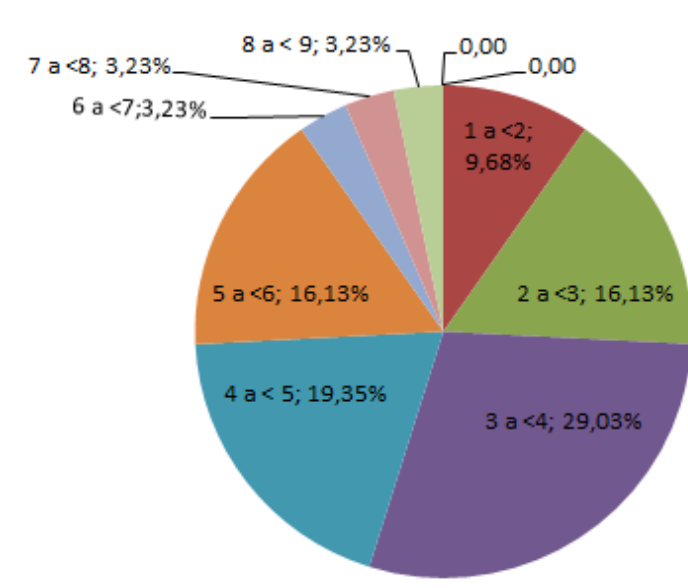

Rendimento turma A na segunda avaliação sem o uso do software 
Tabela 8 - Notas dos alunos da turma $B$ antes do uso do Geogebra

\begin{tabular}{|c|c|c|c|c|c|c|}
\hline \multirow[b]{2}{*}{ Nota } & \multicolumn{6}{|c|}{ Turma $B$} \\
\hline & $\begin{array}{l}\text { Número de } \\
\text { Alunos 1a }\end{array}$ & $\%$ & $\%$ Acumulada & $\begin{array}{c}\text { Numero de } \\
\text { Alunos 2a }\end{array}$ & $\%$ & $\%$ Acumulada \\
\hline $0 a<1$ & 4 & 14,29 & 14,29 & 3 & 10,71 & 10,71 \\
\hline $1 \mathrm{a}<2$ & 2 & 7,14 & 21,43 & 5 & 17,86 & 28,57 \\
\hline $2 a<3$ & 1 & 3,57 & 25,00 & 4 & 14,29 & 42,86 \\
\hline $3 a<4$ & 6 & 21,43 & 46,43 & 7 & 25,00 & 67,86 \\
\hline $4 a<5$ & 6 & 21,43 & 67,86 & 4 & 14,29 & 82,14 \\
\hline $5 a<6$ & 5 & 17,86 & 85,71 & 2 & 7,14 & 89,29 \\
\hline $6 a<7$ & 2 & 7,14 & 92,86 & 2 & 7,14 & 96,43 \\
\hline $7 a<8$ & 2 & 7,14 & 100,00 & 1 & 3,57 & 100,00 \\
\hline $8 a<9$ & - & 0,00 & 0,00 & - & 0,00 & 100,00 \\
\hline $9 a<10$ & - & 0,00 & 0,00 & - & 0,00 & 0,00 \\
\hline Total & 28 & 100,00 & - & 28 & 100,00 & - \\
\hline
\end{tabular}

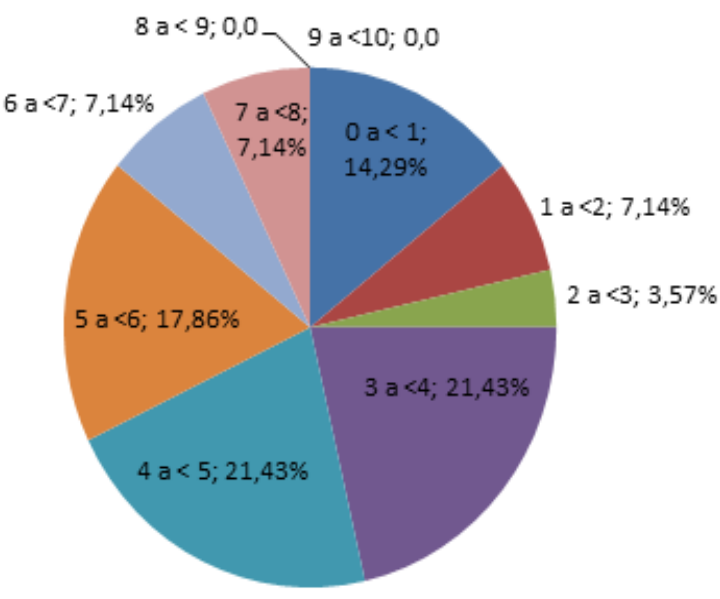

Rendimento turma B na primeira avaliação sem o uso do software

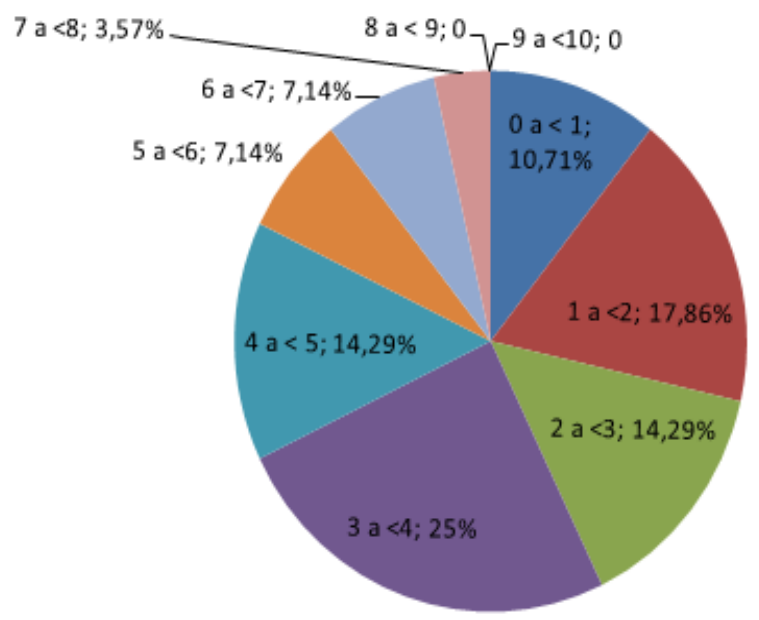

Rendimento turma B na segunda avaliação sem o uso do software

Gráfico 2-Rendimento turma B antes do uso do software 
Tabela 9 - Notas dos alunos da turma $C$ antes do uso do Geogebra

\begin{tabular}{|c|c|c|c|c|c|c|}
\hline & \multicolumn{7}{|c|}{ Turma C } \\
\hline Nota & $\begin{array}{c}\text { Número de } \\
\text { Alunos 1 }\end{array}$ & $\%$ & $\%$ Acumulada & $\begin{array}{c}\text { Numero de } \\
\text { Alunos 2 }\end{array}$ & $\%$ & $\begin{array}{c}\% \\
\text { Acumulada }\end{array}$ \\
\hline $0 \mathrm{a}<1$ & & 0,00 & 0,00 & 2 & 8,00 & 8,00 \\
\hline $1 \mathrm{a}<2$ & 4 & 16,00 & 16,00 & 3 & 12,00 & 20,00 \\
\hline $2 \mathrm{a}<3$ & 2 & 8,00 & 24,00 & 3 & 12,00 & 32,00 \\
\hline $3 \mathrm{a}<4$ & 5 & 20,00 & 44,00 & 7 & 28,00 & 60,00 \\
\hline $4 \mathrm{a}<5$ & 6 & 24,00 & 68,00 & 4 & 16,00 & 76,00 \\
\hline $5 \mathrm{a}<6$ & 4 & 16,00 & 84,00 & 4 & 16,00 & 92,00 \\
\hline $6 \mathrm{a}<7$ & 3 & 12,00 & 96,00 & 2 & 8,00 & 100,00 \\
\hline $7 \mathrm{a}<8$ & 1 & 4,00 & 100,00 & & 0,00 & 100,00 \\
\hline $8 \mathrm{a}<9$ & & 0,00 & 0,00 & & 0,00 & 100,00 \\
\hline $9 \mathrm{a}<10$ & & 0,00 & 0,00 & & 0,00 & 0,00 \\
\hline Total & 25 & 100,00 & & 25 & 100,00 & \\
\hline
\end{tabular}

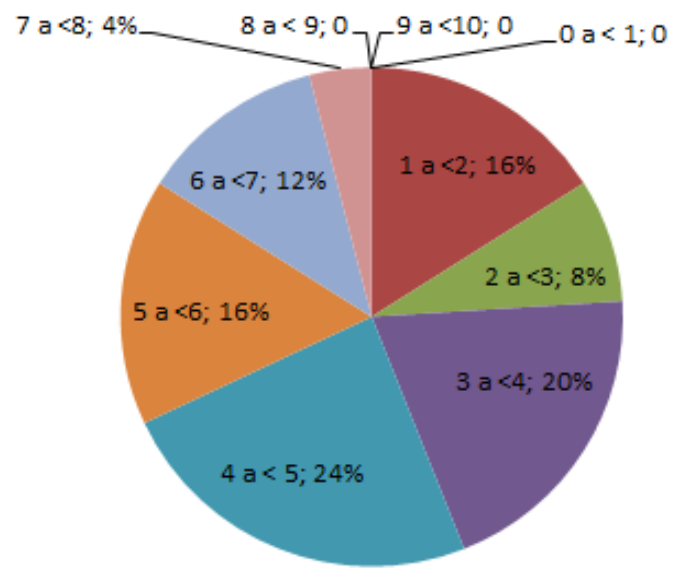

Rendimento turma C na primeira avaliação sem o uso do software

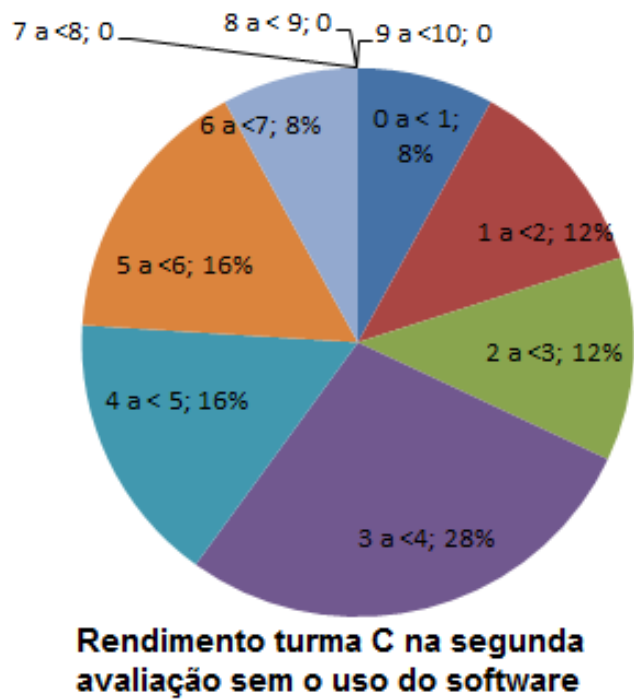

avaliação sem o uso do software

Gráfico 3-Rendimento turma C antes do uso do software 
A Tabela 10 representa as notas dos alunos sem separação de turmas.

Tabela 10 - Nota geral dos alunos antes do uso do Geogebra

\begin{tabular}{|c|c|c|c|c|c|c|}
\hline \multirow[b]{2}{*}{ Nota } & \multicolumn{6}{|c|}{ Turma Geral } \\
\hline & $\begin{array}{l}\text { Número de } \\
\text { Alunos 1a }\end{array}$ & $\%$ & $\begin{array}{c}\% \\
\text { Acumulada }\end{array}$ & $\begin{array}{l}\text { Numero de } \\
\text { Alunos 2a }\end{array}$ & $\%$ & $\begin{array}{c}\% \\
\text { Acumulada }\end{array}$ \\
\hline $0 a<1$ & 5 & 5,95 & 5,95 & 8 & 9,52 & 9,52 \\
\hline $1 \mathrm{a}<2$ & 9 & 10,71 & 16,67 & 13 & 15,48 & 25,00 \\
\hline $2 a<3$ & 6 & 7,14 & 23,81 & 16 & 19,05 & 44,05 \\
\hline $3 a<4$ & 18 & 21,43 & 45,24 & 20 & 23,81 & 67,86 \\
\hline $4 a<5$ & 19 & 22,62 & 67,86 & 13 & 15,48 & 83,33 \\
\hline $5 a<6$ & 15 & 17,86 & 85,71 & 7 & 8,33 & 91,67 \\
\hline $6 a<7$ & 7 & 8,33 & 94,05 & 5 & 5,95 & 97,62 \\
\hline $7 a<8$ & 5 & 5,95 & 100,00 & 2 & 2,38 & 100,00 \\
\hline $8 a<9$ & - & 0,00 & 0,00 & - & 0,00 & 0,00 \\
\hline $9 a<10$ & - & 0,00 & 0,00 & - & 0,00 & 0,00 \\
\hline Total & 84 & 100,00 & - & 84 & 100,00 & - \\
\hline
\end{tabular}

Analisando a Tabela 10 podemos verificar que cerca de $68 \%$ dos alunos apresentaram notas inferiores a 5 na primeira avaliação e na segunda avaliação esse número foi crescente indicando que cerca de $83 \%$ dos alunos não atingiram nota superior a 5 .

Verificando turma a turma, notamos que os números representam uma constante em relação aos números da Tabela 10 onde na primeira avaliação o rendimento inferior a nota 5 corresponde a aproximadamente $68 \%$ dos alunos e na segunda avaliação entre $76 \%$ a $83 \%$.

Verificamos que na turma $B$ o índice de alunos, com rendimento abaixo de 5 foi menor, porém preocupante pelo fato de ser de $76 \%$.

$\left(\right.$ TAVARES,2005) ${ }^{[13]}$ e $(\text { SANTOS,2005) })^{[11]}$, afirmam que os objetos de aprendizagem, podem se configurar como organizadores prévios e como pontes cognitivas, facilitadores de uma aprendizagem mais específica que se inicia com um entendimento consistente dos conceitos mais inclusivos do tema considerado.

Concordamos com (NOVAK, 2003) ${ }^{[8]}$ que:

"Não é possível para o aprendiz alcançar altos níveis de aprendizagem significativa antes que as estruturas cognitivas adequadas sejam construídas, e assim o processo de aprendizagem deve ser interativo ao longo do tempo, para que se possa alcançar o domínio do conhecimento ao nível de um especialista no assunto (NOVAK, 2003)." 
Para que os alunos fossem encorajados à aprendizagem significativa inserimos novas tarefas semelhantes, para que fizessem relações entre os conhecimentos prévios e as novas informações inseridas, através do uso do software Geogebra.

Por isso as avaliações devem ser formuladas de tal modo que levem os alunos a pensarem, a refletirem sobre os conteúdos abordados e que não exijam respostas de imediato para favorecer a aprendizagem.

\section{2 - Atividades utilizadas após o uso do Geogebra e resultados}

Uma vez utilizado o Geogebra, começamos a observar e a estudar o comportamento dos alunos enquanto executores do processo. Foi possível, inicialmente, verificar uma parcela quantitativa não muito grande de alunos que não possuíam familiaridade com computadores, seja pelo fato de não possuírem um, ou por não utilizarem na própria escola ou fora da mesma. Porém, a familiaridade em usar celulares, ou mesmo smartphones, fez com que rapidamente adquirissem certa desenvoltura.

Em um segundo momento, deparamos com o fato que os alunos não conheciam o software Geogebra. Para isso, foi apresentado algumas ferramentas da interface do Geogebra. Tomamos o cuidado de dispor os alunos de 2 em 2 nos computadores disponíveis no laboratório de modo a colocar sempre um com mais prática na condução dos micros.

Com os alunos locados passamos a executar as primeiras atividades propostas no Capítulo 3, onde parte dos conceitos teóricos sobre óptica, foram revisados.

Em cada aula onde era aplicado o uso do Geogebra, surgiram discussões sobre os temas abordados, além de inseridos novos conceitos que complementavam os temas propostos, como também observamos que as habilidades em trabalhar com o Geogebra aumentavam gradativamente.

Após o primeiro contato com o software Geogebra, os alunos conseguiram em suas casas instalar o Geogebra pela Internet sem grandes dificuldades.

Em determinadas atividades como algumas que exigiam maiores relações matemáticas geométricas, apareceram dúvidas em relação à soma de ângulos 
internos e externos, conceitos como perpendicularidade, pontos de intersecção, relações trigonométricas, razão e proporção, explicadas pelo Professor.

Foi possível não só investigar alguns conceitos físicos, mas como também investigar relações entre elementos geométricos e relações trigonométricas em triângulo retângulo em uma das atividades, por exemplo, a atividade 4.

Importante frisar que todas as atividades foram monitoradas pelo docente. Porém, fato curioso foi que três alunos, após o estudo da refração conseguiram reproduzir em casa uma das atividades, sem acompanhamento, como indicado na figura 23.

Houve uma percepção na capacidade de manter o foco, atenção e disciplina por parte dos alunos, enquanto executavam as atividades, demonstrando assim um aumento na motivação em construir uma figura geométrica no Geogebra, diferentemente de quando se usava apenas régua e lápis, durante as aulas que antecederam o uso do software.

Através de diálogos com os alunos ao término de cada aula com o uso do Geogebra, verificamos que os alunos comentavam sobre as atividades e abriam discussões sobre o uso de ferramentas do software.

Verificamos que a satisfação dos alunos era maior e que gostariam que mais aulas como essa fossem realizadas. Chegaram a indicar a outros professores de outras disciplinas, o software Geogebra.

(AUSUBEL,1980) $^{[1]}$ retrata que a vontade do aprendiz é elemento crucial para que possa ocorrer aprendizagem significativa.

Em relação a avaliação final, elaboramos cinco questões problemas, para que os mesmos fizessem as atividades propostas com o uso do Geogebra e em seguida formulassem as respostas. Tomamos o cuidado para que as questões não fossem idênticas as questões propostas antes do uso do Geogebra, buscando o máximo de semelhança entre elas para que então pudéssemos comparar os resultados.

Salientamos aqui que os resultados das atividades avaliativas I e II foram apresentados as turmas e após a aplicação do teste final (Anexo III) puderam perceber que os conceitos trabalhados não mais apresentavam tanta dificuldade no entendimento. As atividades realizadas com o Geogebra contribuíram significativamente para o aprendizado e entendimento de conceitos matemáticos e físicos pelos alunos. Podemos verificar maior rendimento no critério de notas das turmas pela Tabela 11 . 
Tabela 11 - Notas das turmas com o uso do Geogebra

\begin{tabular}{|c|c|c|c|c|c|c|c|c|c|}
\hline & \multicolumn{3}{|c|}{ Turma $A$} & \multicolumn{3}{|c|}{ Turma $B$} & \multicolumn{3}{|c|}{ Turma $C$} \\
\hline Nota & $\begin{array}{c}\text { Número } \\
\text { de } \\
\text { Alunos }\end{array}$ & $\%$ & $\begin{array}{c}\% \\
\text { Acumulada }\end{array}$ & $\begin{array}{c}\text { Número } \\
\text { de } \\
\text { Alunos }\end{array}$ & $\%$ & $\begin{array}{c}\% \\
\text { Acumulada }\end{array}$ & $\begin{array}{c}\text { Número } \\
\text { de } \\
\text { Alunos }\end{array}$ & $\%$ & $\begin{array}{c}\% \\
\text { Acumulada }\end{array}$ \\
\hline $0 a<1$ & - & 0,00 & 0,00 & - & 0,00 & 0,00 & - & 0,00 & 0,00 \\
\hline $1 a<2$ & - & 0,00 & 0,00 & 2 & 7,14 & 7,14 & 2 & 8,00 & 8,00 \\
\hline $2 a<3$ & 4 & 12,90 & 12,90 & 1 & 3,57 & 10,71 & 2 & 8,00 & 16,00 \\
\hline $3 a<4$ & 5 & 16,13 & 29,03 & 4 & 14,29 & 25,00 & 3 & 12,00 & 28,00 \\
\hline $4 a<5$ & 5 & 16,13 & 45,16 & 5 & 17,86 & 42,86 & 8 & 32,00 & 60,00 \\
\hline $5 a<6$ & 11 & 35,48 & 80,65 & 9 & 32,14 & 75,00 & 4 & 16,00 & 76,00 \\
\hline $6 \mathrm{a}<7$ & 2 & 6,45 & 87,10 & 3 & 10,71 & 85,71 & 4 & 16,00 & 92,00 \\
\hline $7 \mathrm{a}<8$ & 4 & 12,90 & 100,00 & 3 & 10,71 & 96,43 & 1 & 4,00 & 96,00 \\
\hline $8 a<9$ & - & 0,00 & 0,00 & 1 & 3,57 & 0,00 & 1 & 4,00 & 100,00 \\
\hline $9 a<10$ & - & 0,00 & 0,00 & - & 0,00 & 0,00 & - & 0,00 & 0,00 \\
\hline Total & 31 & 100,00 & - & 28 & 100,00 & - & 25 & 100,00 & - \\
\hline
\end{tabular}

$\mathrm{Na}$ Tabela 12, apresentamos as notas do conjunto de todos os alunos. Ao analisarmos os dados das Tabelas 11 e 12 verificamos que novamente nenhum aluno, atingiu notas compreendida entre 9 e 10, mas foi possível observarmos um numero maior de alunos que antes não atingiram $50 \%$ da nota, apresentarem durante a realização das atividades com o Geogebra maior motivação em quererem aprender o conteúdo a medida que as dúvidas surgiam e o professor era requisitado. Uma vez que as dúvidas iam sendo resolvidas, os alunos se tornavam cada vez mais autônomos.

Tabela 12 - Nota geral dos alunos com o uso do Geogebra

\begin{tabular}{|c|c|c|c|}
\hline & \multicolumn{3}{|c|}{ Total dos Alunos } \\
\hline Nota & Número de Alunos & $\%$ & \% Acumulada \\
\hline $0 \mathrm{a}<1$ & 0 & 0,00 & 0,00 \\
\hline $1 \mathrm{a}<2$ & 4 & 4,76 & 4,76 \\
\hline $2 \mathrm{a}<3$ & 7 & 8,33 & 13,10 \\
\hline $3 \mathrm{a}<4$ & 12 & 14,29 & 27,38 \\
\hline $4 \mathrm{a}<5$ & 18 & 21,43 & 48,81 \\
\hline $5 \mathrm{a}<6$ & 24 & 28,57 & 77,38 \\
\hline $6 \mathrm{a}<7$ & 9 & 10,71 & 88,10 \\
\hline $7 \mathrm{a}<8$ & 8 & 9,52 & 97,62 \\
\hline $8 \mathrm{a}<9$ & 2 & 2,38 & 100,00 \\
\hline $9 \mathrm{a}<10$ & 0 & 0,00 & 100,00 \\
\hline Total & 84 & 100,00 & 100,00 \\
\hline
\end{tabular}




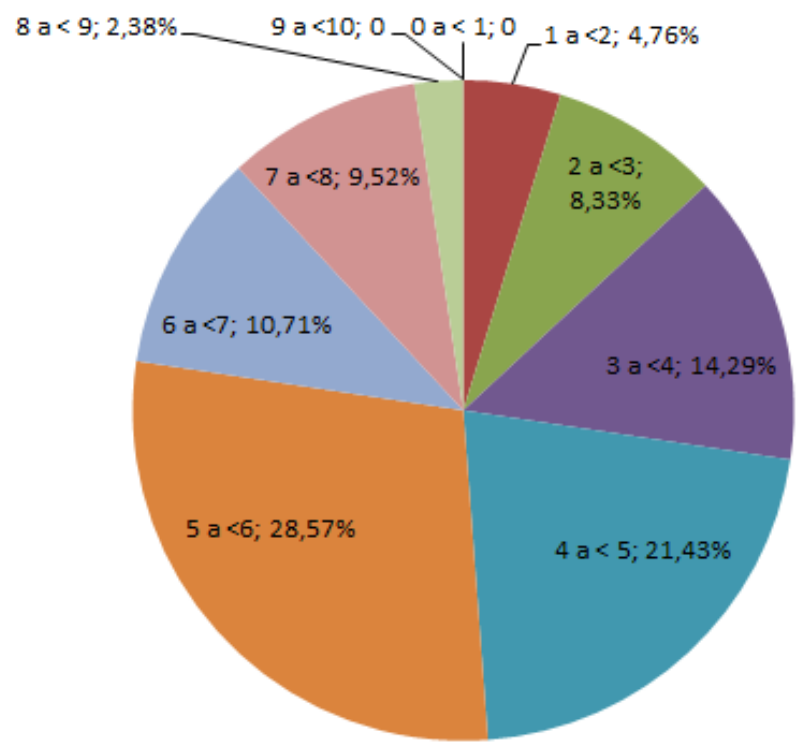

Gráfico 4-Rendimento geral dos alunos após o uso do software

$\mathrm{Na}$ Tabela 13 percebemos um quadro evolutivo em relação ao número de acertos referente às notas. Antes tínhamos um quadro onde cerca de $68 \%$ dos alunos não haviam atingido nota 5 , enquanto o novo quadro apresenta um valor de $45 \%$ que não atingiram, significando que cerca de 20 alunos do total de 84 atingiram nota superior a 5 . Também observamos que houve uma redução entre os alunos com notas inferiores a 4, 3, 2 e 1, bem como nenhum aluno ficou com nota zero.

A faixa de notas que mais cresceu foi a dos alunos que ficaram entre 5 e 6 . Uma melhora significativa entre alunos que conseguiram atingir notas 7 a 8 que até então não haviam conseguido, também houve e uma parcela muito pequena deles atingiram nota entre 8 a 9.

Tabela 13 - Comparativo de notas antes e depois do uso do Geogebra

\begin{tabular}{|c|r|r|}
\hline & $\%$ Antes & \%Depois \\
\hline Nota & & \\
\hline $0 \mathrm{a}<1$ & 7,74 & 0,00 \\
\hline $1 \mathrm{a}<2$ & 13,20 & 4,90 \\
\hline $2 \mathrm{a}<3$ & 13,11 & 7,46 \\
\hline $3 \mathrm{a}<4$ & 24,61 & 11,59 \\
\hline $4 \mathrm{a}<5$ & 19,04 & 21,57 \\
\hline $5 \mathrm{a}<6$ & 14,10 & 30,64 \\
\hline $6 \mathrm{a}<7$ & 8,20 & 11,74 \\
\hline $7 \mathrm{a}<8$ & 0,00 & 9,72 \\
\hline $8 \mathrm{a}<9$ & 0,00 & 2,38 \\
\hline $9 \mathrm{a}<10$ & 0,00 & 0,00 \\
\hline Total & 100,00 & 100,00 \\
\hline
\end{tabular}




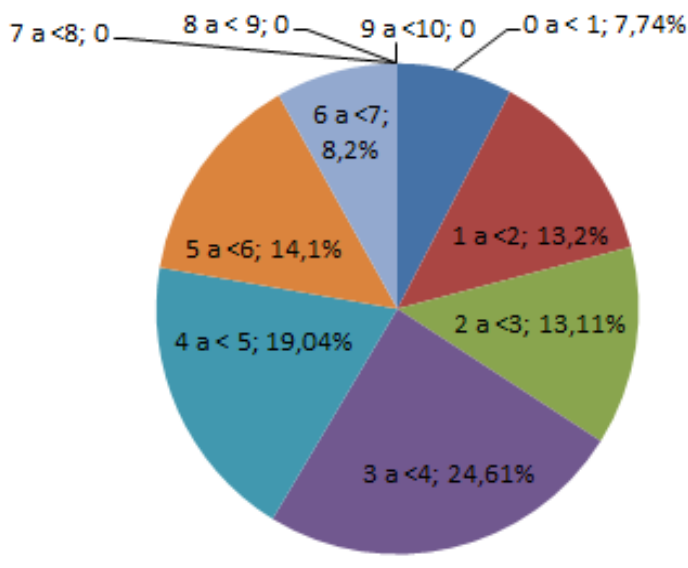

Rendimento geral antes do uso do software

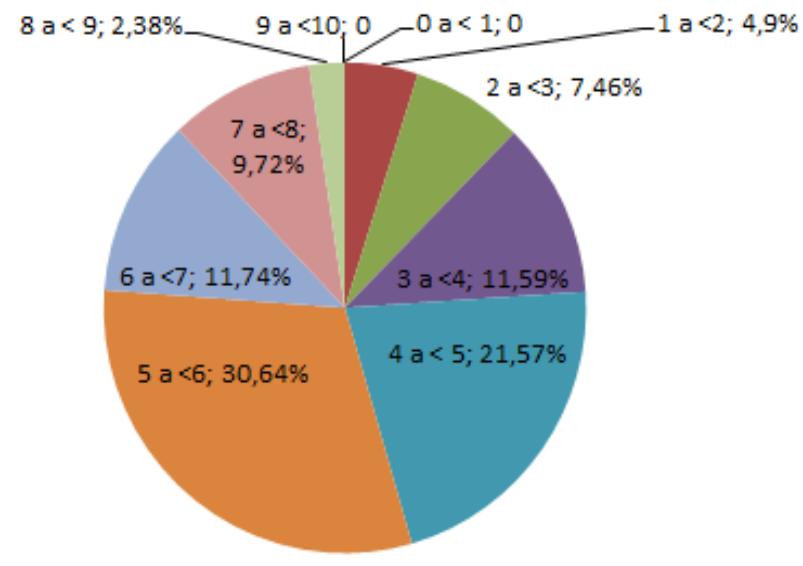

Rendimento geral depois do uso do software

Gráfico 5-Rendimento geral antes e depois do uso do software

Verificamos que o uso de objetos de aprendizagem tornou-se um grande diferencial para a aprendizagem significativa. Novamente citamos (AUSUBEL, $1980)^{[1]}$, que retrata que para que se ocorra aprendizagem significativa o estudante deve ter vontade em aprender, conhecimentos prévios em sua estrutura cognitiva e ambiente propício para desenvolvimento de suas habilidades.

Os avanços obtidos através do uso do Geogebra demonstraram em um curto espaço de tempo, que é possível melhorar ainda mais o desempenho dos alunos.

Resultados esses que demonstraram que o uso do Geogebra pode contribuir para a aprendizagem multidisciplinar entre as áreas do saber, nesse caso a Física e a Matemática.

Para obtermos resultados, mesmo que pequenos se faz necessário planejamento das ações no que se refere ao tema escolhido, a construção das atividades, os caminhos que serão traçados para sua realização, a fim de que, o software possa proporcionar a recuperação de conceitos como também no processo de aceleração da apropriação de saberes. 


\section{Capítulo 5}

\section{Considerações Finais}

Diante das grandes transformações que a educação no âmbito nacional atravessa, verificamos a grande necessidade de se reavaliar as práticas metodológicas e as metodologias utilizadas na educação básica.

Não basta o professor se apossar de um conteúdo especifico, e que o mesmo se feche ou que não seja receptivo a essas transformações, sobretudo ao aprendizado de manuseio de novas tecnologias.

Hoje há uma vasta quantidade de softwares, que permite a criação de várias atividades interativas digitais, que embora pouco utilizados no Brasil, já são de uso em grande escala em países onde se verificam um crescente investimento em educação, e também na formação dos professores, capacitando-os.

Em particular, o Geogebra tem demonstrado ser um software, com grande diversidade se não de recursos ferramentais, mas de construção geométrica entre outras aplicações, que pode se encontrar hoje no ambiente virtual, a Internet.

O mesmo propicia a criação de ambientes de aprendizagens, que favorece 0 crescimento do aluno no aspecto cognitivo, despertando motivação, é de fácil acesso e gratuito de modo que o mesmo pode ser utilizado sem limitações e ou qualquer burocracia em relação a licenças.

Acreditamos que quanto mais ricos forem os recursos de um software, mais acessíveis aos alunos se tornam em relação a problemas e ideias matemáticas significativas.

É importante salientar que as tecnologias digitais, aplicadas ao ensino não são suficientes para garantir a construção do conhecimento. Dai a necessidade do professor como o agente principal na elaboração das atividades, no planejamento e 
muitas vezes no replanejamento para que garanta ao aluno, a acessibilidade à aprendizagem real.

O cuidado em verificar o que se julga importante a ser ensinado é primordial, pincipalmente na matemática onde muitos acabam por serem desmotivados a aprender e que podem interferir na aprendizagem de outras ciências entre elas a física. Não basta apresentar um software ou mesmo simuladores de geometria ou álgebra sem que as atividades sejam previamente planejadas. Se assim ocorrer, corremos o risco de não atingirmos os objetivos e tal prática cair em desuso ou mesmo ser abandonada, por não ter dado certo pela falta de empenho do docente que não planejou as atividades.

Em contrapartida é importante que o aluno possa explorar o software, quando possível sozinho, de modo que o mesmo possa criar novas ideias tal como um instrumentista que ao aprender as notas básicas passa a treinar e desenvolve seu próprio repertório e combinações de notas, mas ainda sim devem ser orientados pelo professor.

Assim o papel do professor se torna o de agente mediador entre o que se ensina e o que é ensinado, entre os saberes e a construção do conhecimento dos alunos. O mesmo tem um papel principal na orientação dos alunos no uso de tecnologias digitais no ensino.

As tecnologias digitais, ainda são consideradas ferramentas simples de suporte ao processo de ensino aprendizagem. Porém frente as mudanças ocasionadas pelas novas tecnologias que tomam conta da vida cotidiana, em todo momento de transição, ocorre o momento de adaptação no que referimos a métodos de ensino e incorporação de novas tecnologias e novos recursos.

A efetiva utilização destes ambientes propícios a aprendizagem, é um grande desafio a ser vencido, sobretudo nos ambientes escolares, quanto ao uso de novas tecnologias digitais (LEVY,1994) ${ }^{[4]}$ :

"É certo que a escola é uma instituição que há cinco mil anos se baseia no falar / ditar do mestre, na escrita manuscrita do aluno e, há quatro séculos, em um uso moderado da impressão. Uma verdadeira integração da informática supõe o abandono de um hábito antropológico mais que milenar, o que não pode ser feito em alguns anos. (LEVY,1994)." 
O desafio envolve a construção dos ambientes de aprendizagem frente a formação e capacitação dos professores e as mudanças curriculares.

É nesse contexto que nossa pesquisa insere-se, mostrando resultados ainda que pequenos, mas de grande relevância no processo ensino-aprendizagem utilizando tecnologias digitais. Recursos esses, que leva-nos a preencher lacunas em consideração a aprendizagem da matemática e da física.

A dinâmica que uma tecnologia digital proporciona, contribui de forma relevante na aprendizagem, porém, não esperamos que o mesmo vá substituir a utilização de lápis, régua e papel, mas que de certo modo contribua para o aperfeiçoamento e melhoria do ensino, como também não esperamos que as aulas em que são inseridas tecnologias digitais, possam solucionar todos os problemas, mas esperamos que as aulas tenham como suporte o uso crescente dessas tecnologias.

Em paralelo a outras pesquisas, essa em particular, pôde demonstrar que o uso do software Geogebra é um recurso pedagógico importante na construção do conhecimento. Vemos com bons olhos o crescimento do uso dessa prática em ambientes escolares.

Entendemos assim, que se faz necessário criar fatores essenciais que levem os alunos a adquirirem uma aprendizagem real. Esperamos também que as atividades sirvam de estímulo aos professores de modo que possam desenvolver aulas dinâmicas, que os conceitos matemáticos possam ser diferenciados a fim de proporcionar maior motivação aos estudantes, além de serem criativas possibilitando aprendizagens significativas na construção ou mesmo na reconstrução de saberes, desenvolvendo no educando novas habilidades e competências frente aos problemas cotidianos.

É preciso no âmbito da educação Matemática valorizar a introdução de novas metodologias, novas tecnologias de informação, e a criação de ambientes de aprendizagem. Que o professor possa sempre se capacitar sobretudo nos ambientes informatizados, o que não indica que o mesmo deva dominar por completo, mas que possa propiciar novas atividades que possam envolver seus alunos em frente as mudanças tecnológicas.

Entre outras possibilidades, ao se capacitar, o professor passa a ter um olhar mais criterioso e investigativo da prática pedagógica e uma constante busca pelas 
inovações no modo de ensinar. O professor deverá sempre repensar sua prática pedagógica, se adequando sempre que possível para novos conhecimentos e dominar meios de ensino/aprendizagem, não se atendo a resistências, e dando ênfase à importância do uso de novas tecnologias na educação, em especial, no ensino da Matemática e da Física. 


\section{Referências Bibliográficas}

[1] AUSUBEL, D. P.; NOVAK, J. D. e HANESIAN, H. Psicologia educacional. Tradução de Eva Nick. Rio de Janeiro: Editora Interamericana Ltda,1980.

[2] CURY, H. N.; A formação dos formadores de professores de Matemática: quem somos, o que fazemos, o que podemos fazer. In: CURY, Helena (org). Formação de professores de matemática, uma visão multifacetada. Porto Alegre: EDIPUCRS, 2001.

[3] D’AMBRÓSIO, U.; Etnomatemática. São Paulo: Editora Ática, 1990. . Educação Matemática: da teoria à prática. São Paulo, SP: Papirus, 1996. . Etnomatemática: elo entre as tradições e a modernidade. Belo Horizonte: Editora Autêntica, 2001.

[4] LEVY, P.; As tecnologias da inteligência - o futuro do pensamento na era da informática. Lisboa, Instituto Piaget, 1994.

[5] LIBÂNEO, J. C.; Organização e gestão da escola - teoria e práticas. Goiânia: Alternativa, 2004.

[6] LUCKESI, C. C;. Considerações gerais sobre avaliação no cotidiano escolar. (Entrevista). Revista Aprender a Fazer, Curitiba, n. 36, 2004, p. 4-6. Disponível em http://goo.gl/IWML7. Acesso em: 07/10/2014.

[7] MORIN, E.; Ciência com Consciência. Rio de Janeiro: Bertrand Brasil, 1996.

[8] NOVAK, J. D.; The Promise of New Ideas and New Technology for Improving Teaching and Learning. Cell Biology Education Vol2, p122,2003.

[9] REIS, M. F.; Educação Tecnológica: a Montanha Pariu um Rato? Portugal: Porto Editora, 1995. 
[10] RICHARDSON, R. J.; Pesquisa Social: Métodos e Técnicas. São Paulo: Atlas, 1999.

[11] SANTOS, J. N.; Uso de ferramentas cognitivas para a aprendizagem de física. .Dissertação (Mestrado) em Física, Orientador: Prof. Dr. Ilde Guedes da Silva. Fortaleza, 2005.

[12] SOARES, M.; Letramento: um tema em três gêneros. $2^{\mathrm{a}}$ ed., Belo Horizonte: Autêntica, 2002.

[13] TAVARES, R.; Animações interativas e mapas conceituais. XVI Simpósio Nacional de Ensino de Física, 2005, Rio de Janeiro. 2005. 


\section{Anexos}

Anexo I - Atividade de avaliação I

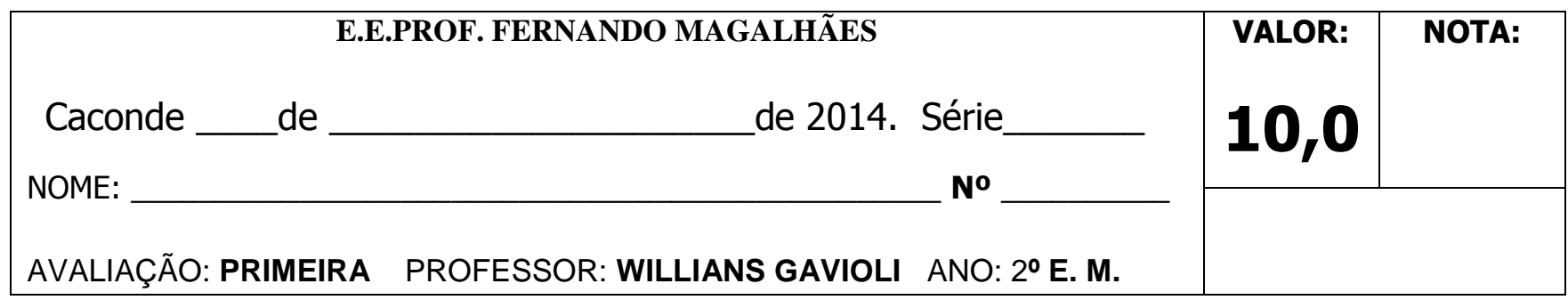

1-(2 pontos)- Uma câmara escura de orifício fornece a imagem de um prédio, o qual se apresenta com altura de $5 \mathrm{~cm}$. Aumentando-se de $100 \mathrm{~m}$ a distância do prédio à câmara, a imagem reduz-se para $4 \mathrm{~cm}$ de altura.

a) Construa um esquema representando o prédio e a câmara escura indicando distancia do objeto á câmara (D), altura do objeto $(\mathrm{H})$ a altura da imagem projetada (h) e espessura da câmara (d).

b)Qual é a distância entre o prédio e a câmara, na primeira posição?

2-(2 pontos)- Para medir a altura de um farol, utilizou-se de um espelho plano colocado na horizontal no mesmo nível das bases do farol e de uma parede que estava a uma distância "D" do farol. Quando um raio de luz do farol reflete no espelho em um ponto $2 \mathrm{D} / 21$ em relação à parede, incide nesta em um ponto que estava a uma altura de $140 \mathrm{~cm}$ de sua base. Determine a altura do farol em metros.

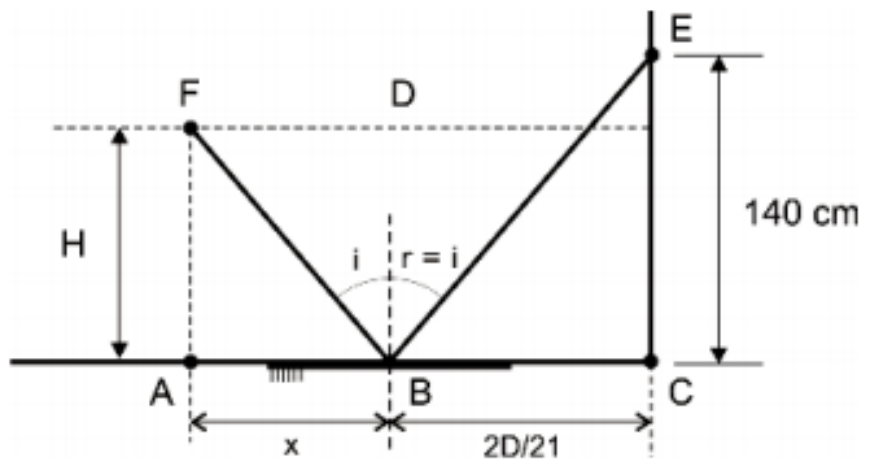


3-(2 pontos)- Considere a figura abaixo e determine o raio de curvatura do espelho esférico $E$, sabendo-se que o tamanho do objeto $A B$ é o triplo de sua imagem A'B'.

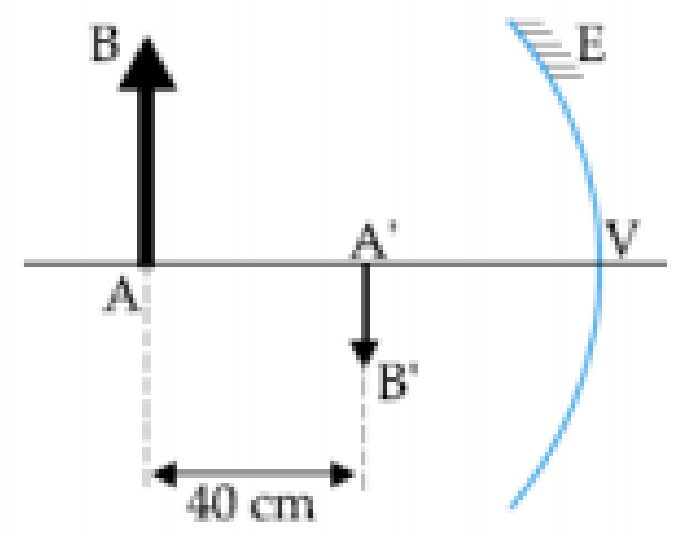

4-(2 pontos)- Sobre o eixo principal de um espelho esférico convexo de raio de curvatura igual a $10 \mathrm{~cm}$, é colocado um objeto real. A distância entre o objeto e o espelho é $20 \mathrm{~cm}$. Desta forma:

a) Desenhe o espelho indicando a posição do objeto e da imagem traçando os raios notáveis.

b) Através da Equação de Gauss e do Aumento linear transversal determine as características da imagem formada por esse espelho.

5-(2pontos)- Um espelho côncavo de $50 \mathrm{~cm}$ de raio e um pequeno espelho plano estão frente a frente. O espelho plano está disposto perpendicularmente ao eixo principal do côncavo. Raios luminosos paralelos ao eixo principal são refletidos pelo espelho côncavo; em seguida, refletem-se também no espelho plano e tornam-se convergentes num ponto do eixo principal distante $8 \mathrm{~cm}$ do espelho plano, como mostra a figura.

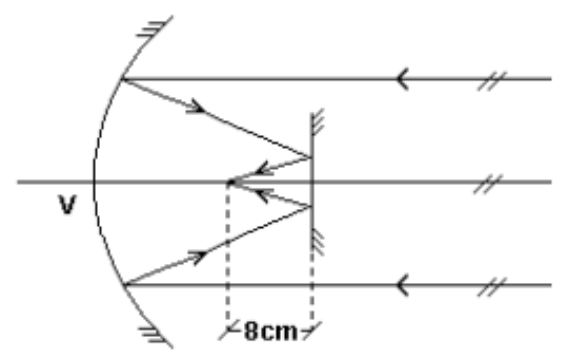

Calcule a distância do espelho plano ao vértice $V$ do espelho côncavo. 
Anexo II - Atividade de avaliação II

E.E.PROF. FERNANDO MAGALHÃES

Caconde de de 2014. Série

NOME:

No

AVALIAÇÃO: SEGUNDA PROFESSOR: WILLIANS GAVIOLI ANO: $2^{\circ}$ E. M.

1-(2 pontos)- Um raio de luz monocromático se propaga no ar e atinge a superfície de um cristal transparente, com ângulo de incidência igual a $60^{\circ}$. Sabendo que o índice de refração do cristal para essa radiação é igual a $\sqrt{3}$, determine o ângulo de refração e complete a figura, desenhando o raio refratado e o ângulo de refração.

Dados: $\operatorname{sen} 30^{\circ}=\frac{1}{2} ; \operatorname{sen} 60^{\circ}=\frac{\sqrt{3}}{2}$

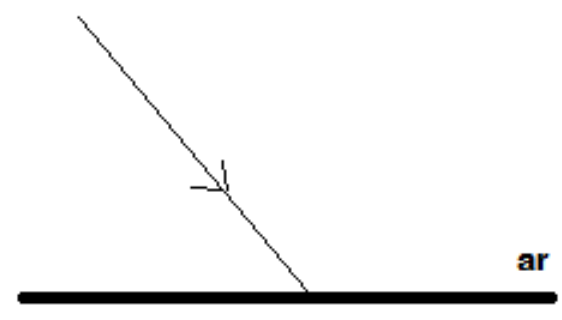

cristal

2-(2 pontos) - (UNESP) A figura a seguir indica a trajetória de um raio de luz que passa de uma região semicircular que contém ar para outra de vidro, ambas de mesmo tamanho e perfeitamente justapostas.

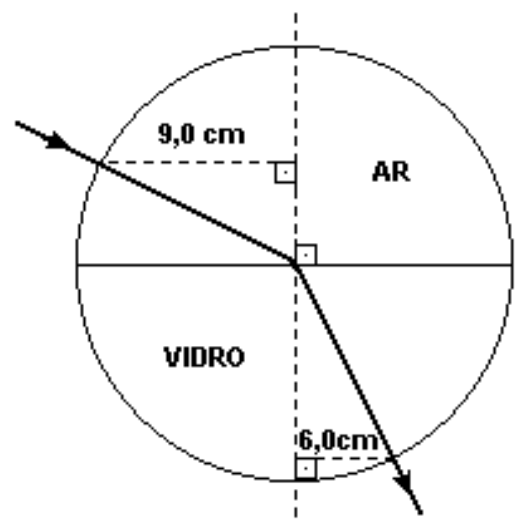

Determine, numericamente, o índice de refração do vidro em relação ao ar. 
3-(2 pontos)- A figura abaixo representa um raio de luz que atravessa um prisma. Determine o desvio sofrido por esse raio de luz em graus.

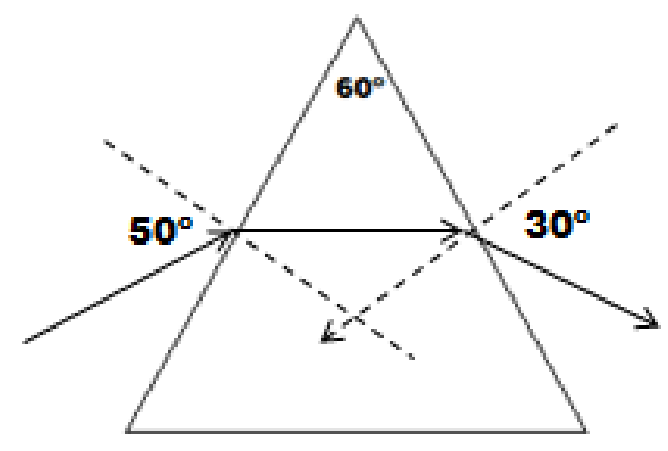

4-(2 pontos)- Um sistema de lentes produz a imagem real de um objeto, conforme a figura a seguir. Calcule a distância focal e localize a posição de uma lente delgada que produza o mesmo efeito traçando os raios notáveis sempre que possível.

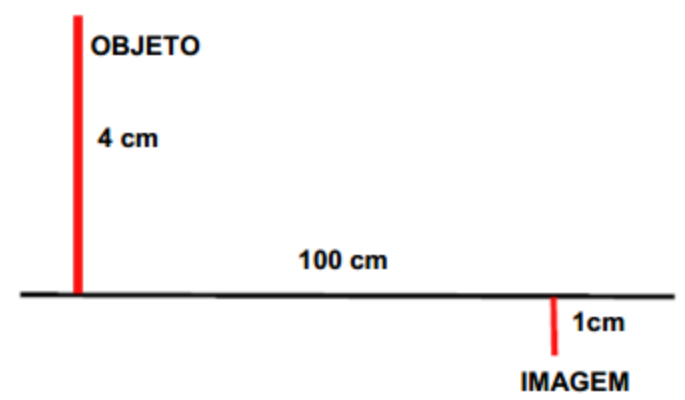

5-(2 pontos)- Uma lâmpada está situada a $100 \mathrm{~cm}$ de distância de uma parede, sobre a qual se deseja projetar uma imagem da lâmpada, usando-se uma lente de distância focal igual a $22 \mathrm{~cm}$. Determine a que distância da parede deve ser colocada a lente para se obter uma imagem nítida e ampliada da lâmpada, desenhe a representação da lente bem como seus pontos notais com objeto e imagem traçando os raios notáveis. 
Anexo III - Atividade de avaliação III pós-uso do software Geogebra

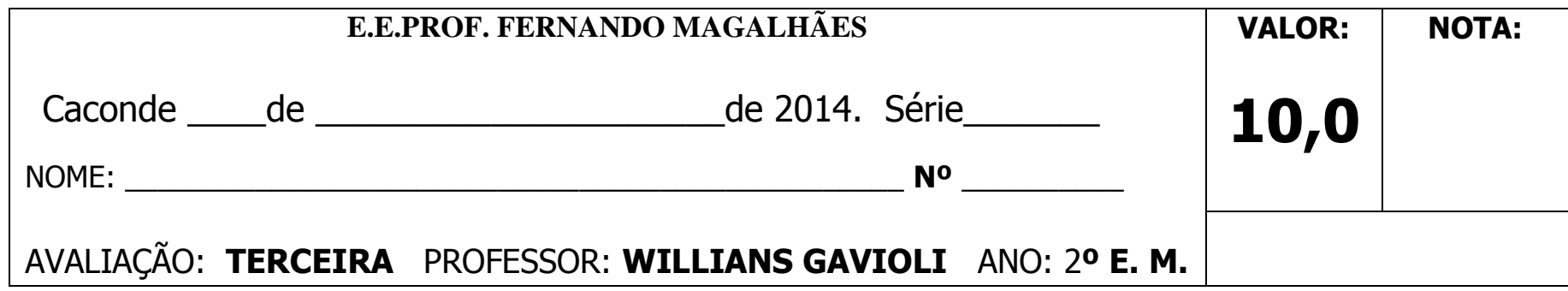

1-(2 pontos)- Um raio de luz incide em um espelho plano horizontal e realiza a trajetória mostrada na figura a seguir. Considera-se que $\operatorname{sen} 37^{\circ}=0,6$ e $\cos 37^{\circ}=$ 0 ,8. Com base nas distâncias indicadas, qual é o valor de L?

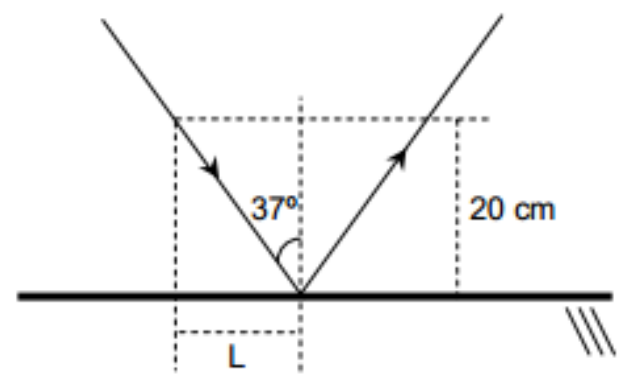

2-(2pontos)- Diante de um espelho esférico côncavo coloca-se um objeto real no ponto médio do segmento definido pelo foco principal e pelo centro de curvatura. Se o raio de curvatura desse espelho é de 2,4 m, determine a distância entre o objeto e sua imagem conjugada, desenhe a posição do objeto, da imagem e do espelho utilizando raios notáveis.

3-(2 pontos)- Um disco de raio $2 \mathrm{~m}$ flutua num líquido de índice de refração desconhecido. Do centro desse disco, desce um fio de prumo de comprimento $2 \sqrt{3}$ m conforme figura abaixo. Calcule o índice de refração n mínimo do líquido, para que o prumo não possa ser visto por nenhum observador acima da superfície. Considere o índice de refração do ar $\mathrm{n}$ igual a 1 . 


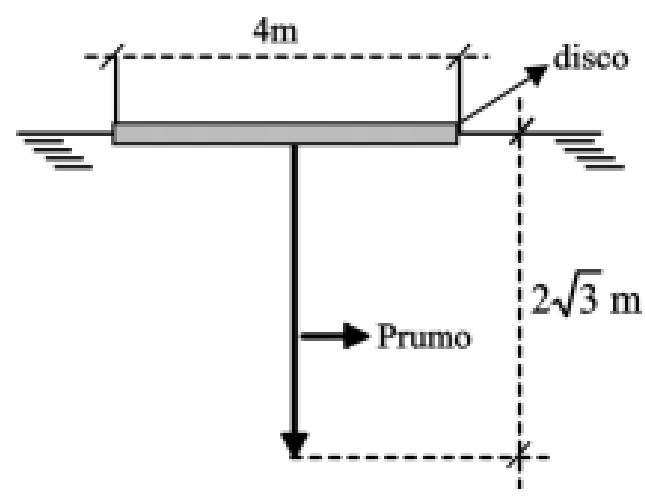

4-(2 pontos)- Um prisma de vidro, cujo ângulo de refringência é $60^{\circ}$, está imerso no ar. Um raio de luz monocromática incide em uma das faces do prisma sob ângulo de $45^{\circ}$ e, em seguida, na segunda face sob ângulo de $30^{\circ}$, como está representado na figura a seguir. Calcule o índice de refração do prisma e o desvio total da luz ao atravessar o prisma.

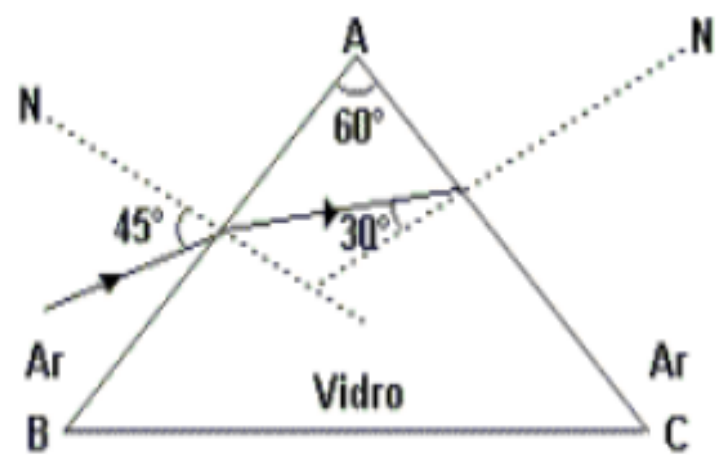

5-(2 pontos)- Um objeto está situado a $10 \mathrm{~cm}$ de uma lente. Sabe-se que sua imagem, fornecida pela lente, é real e tem a altura igual à metade da altura do objeto.

a) Qual é a distância da imagem à lente?

b) Determine o valor da distância focal da lente?

c) Esta lente é convergente ou divergente?

d) Construa um esquema representando lente, objeto e imagem traçando os raios notáveis. 